\title{
Alternative Standards of Independence and Impartiality
}

This Chapter analyzes how select dispute resolution mechanisms delimit arbitrators' independence and impartiality. The examined mechanisms are chosen based on their similarities with ICSID arbitration, which will be set out below, at the beginning of each Part. As in Chapter 2, the focus of the analysis is on the threshold for arbitrator challenges, and the application of the abstract requirement of independence and impartiality to specific conflict categories. ${ }^{454}$ The analysis of the relevant rules, as well as the case law (where available) allows for an informed and detailed comparison of challenge outcomes at the end of the Chapter.

International Adjudication

\subsection{Relevance}

ICSID arbitration deals with States' obligations under public international law. Host States' substantive obligations derive from the BITs they have entered into, or from customary international law, while their consent to investment arbitration is usually formalized in the respective BIт. ${ }^{455}$ Both the substantive and the procedural ramifications of investment disputes are therefore governed by public international law. ${ }^{456}$ Similarly to the European Court of Human Rights in the context of individual applications, ${ }^{457}$ ICSID arbitrators decide private parties' claims against States for the alleged breach of international obligations.

454 Technicalities of the appointment, disclosure and challenge process (i.e. delays for challenges) are not examined.

455 Eric De Brabandere, Investment Treaty Arbitration as Public International LaW. Procedural Aspects and Implications 2 (2014).

456 Wouters and Hachez, supra note 19, at 618.

457 See European Convention on Human Rights, Nov. 4, 1950, ETS 5 (entered into force Sept. 3, 1953), as amended by Protocols No. 11 and 14, CETS 194 (entered into force June 1, 2010), art. 34 . 
Beyond resolving specific disputes, ICSID tribunals effectively have a governance function in the field of investment law. ${ }^{458}$ Although their awards do not formally have the effect of precedents, in practice arbitrators often observe previous decisions, and decide in a way that preserves at least some degree of coherence. ${ }^{459}$ This effect is facilitated and enhanced by three factors: the increased transparency of ICSID awards, the similarity of unrelated BITs, which often have a comparable structure and contain the same clauses, and the increase in the number of disputes filed based on such provisions. ${ }^{460}$ As a consequence, there is an actual ICSID jurisprudence in some areas of investment law, although the disputes from which this case law emanates are (strictly speaking) based on unrelated BITs. Arbitral tribunals create largely uniform rules of investment law or interpretations thereof.

On the reverse side of the described crystallization of standards of investment protection, the scope within which States as sovereigns are free to regulate ${ }^{461}$ public interests is increasingly standardized by arbitral tribunals. ${ }^{462} \mathrm{As}$ a consequence, ICSID arbitrators progressively become architects not only of the international investment environment, but also of public international law and domestic administrative law. ${ }^{463}$ The influence they exert on States'

$45^{8}$ The concept of governance referred to herein is inspired by Montт, supra note 26, at 133-135 and Daniel C. Esty, Good Governance at the Supranational Scale: Globalizing Administrative Law, 115 YALE L.J. 1490, 1499 (2006).

459 Rogers, Еthics, supra note 98, ๆ 6.50.

460 Wouters and Hachez, supra note 19, at 616 .

461 It is true that awards aim at monetary compensation, as opposed to specific performance (see Martin Endicott, Remedies in Investor-State Arbitration: Restitution, Specific Performance and Declaratory Awards, in New Aspects of International Investment LAW 517 (Philippe Kahn \& Thomas W. Wälde eds., 2007)), and therefore do not immediately restrict States' regulatory freedom. In practice, however, the scale of the threatened payment in damages has a chilling effect on regulatory initiatives in host States (id. at 632). The threatened claims are sometimes so high that they imperil the financial situation of the Respondent State, and arbitral tribunals have a reputation for showing less self-restraint when granting damages, compared to "other international judicial mechanisms directly accessible to individuals" (Wouters and Hachez, supra note 19, at 622).

462 Wouters and Hachez, supra note 19, at 616 (describing investor-State arbitration as "a mechanism of judicial review of the regulatory acts of the host State"); Rivkin, supra note 18 , at 353 .

463 Wouters and Hachez, supra note 19, at 625 (arguing that arbitral tribunals' de facto restrictions on host States' regulatory sovereignty give the tribunals a "quasi-constitutional" character); Rivkin, supra note 18, at 341; Alexandra Diehl, The Core Standard of International Investment Protection 5 (2012). 
regulatory sovereignty in this function is not negligible: Arbitration tribunals effectively develop international law standards. ${ }^{464}$ In the words of Sundaresh Menon, the former Chief Justice of Singapore:

The arbitrator today is the custodian of what is rapidly becoming the primary justice system integral to the proper functioning of international trade and commerce. ${ }^{465}$

In light of these far-reaching powers of investment arbitrators, the substance of international investment arbitration is said to be much more reminiscent of an administrative regulatory review mechanism, than of commercial arbitration. ${ }^{466}$ Unlike commercial arbitration, investment arbitration was not conceived to preserve private parties' freedom to make private arrangements. ${ }^{467}$ Instead, it aims to balance States' regulatory sovereignty and the legitimate expectations of foreign investors, in order to create the "common ground necessary to promote the security of transborder exchanges." ${ }^{n 68}$ As such, it resembles an internationalized public law adjudication mechanism. ${ }^{469}$

Based on these similarities, the rules on the independence and impartiality of international adjudicators who are appointed by the parties, on an ad hoc basis, lend themselves particularly well for a comparison with the standards applicable to ICSID arbitrators. ${ }^{470}$ Not only do their functions (i.e. the qualification of the substantive questions they decide) coincide; their appointment by the parties, for the purpose of deciding a specific case, is likely to give rise to similar potential conflicts of interest as those invoked in the ICSID system.

464 Montт, supra note 26, at 126; Gabrielle Kaufmann-Kohler, Arbitral Precedent: Dream, Necessity or Excuse?, 23 Ав в. In T'L. 357, 373 (2007); James Crawford, International Protection of Foreign Direct Investments: Between Clinical Isolation and Systemic Integration, in International InVestment LaW and General International LaW: From Clinical Isolation to Systemic Integration? 17, 22 (Rainer Hofmann \& Christian J. Tams eds., 2011) (“[I]n some very important way investment law, like human rights law is about the state and not just about corporations or individuals. It is about the way in which we bring the state under some measure of control, which is the main aspiration of general international law."); Rivkin, supra note 18, at 346.

465 Menon, supra note 38 , at 13 .

466 Wouters and Hachez, supra note 19, at 625 and 630.

467 See Paulsson, The Idea, supra note 22, at 24 in the context of commercial arbitration.

468 Paulsson, The IdeA, supra note 22, at 137.

469 Brower and Rosenberg, supra note 122, at 28; Rivkin, supra note 18, at 352.

470 De BRABANDERE, supra note 455 , at 2. 
Insight might thus be gained from the different approaches of these systems to the same issues.

The rules applicable to the permanent members of the relevant decisionmaking bodies will be mentioned hereinafter, but are analyzed in less detail. Institutional guarantees insulate these "international judges" from the parties, making conflicts of the nature as they arise in ICSID arbitration both less frequent and less suspect. Any potential predispositions of these decisionmakers are coincidental, and not specifically sought out by one of the disputing parties, in order to gain an advantage in the dispute. Thus, the need to distinguish the benign and legitimate exercise of a party's autonomy to appoint its decision-maker on the one hand, and improper dependence and bias on the other hand does not arise with regard to the permanent members of international adjudication mechanisms.

\subsection{The International Court of Justice}

The International Court of Justice (hereinafter the ICJ or the Court) is the "principal judicial organ of the United Nations." 471 It was established by the U.N. Charter in 1946, and functions according to the rules of the Statute of the International Court of Justice (ICJ-Statute) $)^{472}$ and its Rules of Court (ICJ Rules). ${ }^{473}$ The ICJ's main function is to settle interstate disputes under international law. ${ }^{474}$

As a permanent court, the ICJ consists of fifteen judges from different countries. The judges are elected by the United Nations General Assembly and the Security Council, from a list of persons nominated by the national groups in the PCA. ${ }^{475}$ States which are not represented on the court may appoint an $\mathrm{ad}$ hoc judge when they are involved in a case. ${ }^{476}$ Because of their appointment by a disputing party, on an ad hoc basis, these decision-makers are considered

471 U.N. Charter art. 92.

472 U.N. Charter art. 92; Statute of the International Court of Justice art.1, June 26, 1945, I.C.J. Acts \& Docs. 59 [hereinafter ICJ-Statute].

473 Rules of Court (1978), Apr. 14, 1978, I.C.J. Acts \& Docs. 91 [hereinafter ICJ Rules].

474 ICJ-Statute art. $34-37$.

475 ICJ-Statute art. 3; art. 4, para. 1. The judges, also referred to as members of the Court, serve for nine years and may be reappointed. The renewal of the Court is staggered: Every three years, a third of the members are elected (ICJ-Statute art. 13, para. 1).

476 ICJ-Statute art. 31, para. 2-3. See Franck, Structure, supra note 41, at 253 ("This is like a sport, which in lieu of enforced rules, allows each side an equal number of foul plays."). 
to be "a concession to the methods of arbitration."477 Their raison d'être is justified with similar arguments as that of arbitrators: Ad hoc judges are said to ensure the disputing States' right to be heard, by helping the Court understand the national law of their appointing country, and to thereby improve the parties' confidence in the ICJ's decisions, and make unfavorable decisions more palatable. ${ }^{478}$

A Independence and Impartiality Requirements

The members of the ICJ are expected to be independent and impartial. 479 Their ability to exercise other political, administrative, and professional roles, and to adjudicate matters in which they were previously involved is severely restricted by the ICJ-Statute. Members of the Court are effectively banned from performing any other legal practice simultaneously:

\section{Article 16}

1. No member of the Court may exercise any political or administrative function, or engage in any other occupation of a professional nature...

\section{Article 17}

1. No member of the Court may act as agent, counsel, or advocate in any case.

An exception from this prohibition is the admissibility of occasional appointments as an arbitrator. Because most national courts and the PCA have a

477 Suh, supra note 122, at 226; Kooijmans, supra note 128, I| 2. See also Jan Paulsson, Moral Hazard in International Dispute Resolution, 25 ICsid REv. 339, 343 (2010) [hereinafter Paulsson, Moral Hazard] (going even further, by referring to ad hoc judges as, "once we overcome pretense, a species of advocate.").

478 See Suh, supra note 122, at 234; Schwebel, National Judges, supra note 122, at 889-890; Kooijmans, supra note 128 , ๆ 2 and 6 ("[H]e or she will usually take care that during the deliberations and in the judgment the views and positions taken by the party which has appointed him or her will be duly reflected."). Contra Thomas Buergenthal, The Proliferation of Disputes, Dispute Settlement Procedures and Respect for the Rule of Law, 22 ARв. INT'L. 495, 498 (2006); PAulsson, The IdeA, supra note 22, at 159.

479 ICJ-Statute art. 2 ("The Court shall be composed of a body of independent judges, elected regardless of their nationality ...") and art. 20 ("Every member of the Court shall, before taking up his duties, make a solemn declaration in open court that he will exercise his powers impartially and conscientiously."); see also ICJ Rules art. 4, para. 1. See Sheppard, supra note 32 , at 135 . 
"long-standing tradition" of permitting judges to serve as arbitrators, the ICJ considers such appointments to be compatible with the judges' functions as members of the Court. ${ }^{480}$ Two conditions must, however, be fulfilled: Firstly, the judges must give absolute precedence to their obligations as members of the Court, and secondly, they should not accept any appointments in cases which might later be submitted to the ICJ. ${ }^{481}$ This exception is expanded to apply to the participation of judges in other occasional judicial or quasi-judicial activities. ${ }^{482}$

A limited exception is further made for the involvement of judges in academia. Members of the Court are barred from holding permanent teaching or administrative positions in universities, but are allowed to participate in occasional "scholarly pursuits in the sphere of international law as members of learned societies or as occasional lecturers." Like judges who occasionally serve as arbitrators, they must give precedence to their judicial duties. ${ }^{483}$

Article 17 para. 2 ICJ-Statute stipulates that members of the Court may not be involved in the same matter, at different stages. In other words, the dual role as a member of the ICJ and as a counsel is not only impermissible when it is exercised simultaneously, but also when it takes place successively, in the same matter:

\section{Article 17}

2. No member may participate in the decision of any case in which he has previously taken part as agent, counsel, or advocate for one of the parties, or as a member of a national or international court, or of a commission of enquiry, or in any other capacity...

480 See U.N. Secretary-General, Conditions of service and compensation for officials other than Secretariat officials, Members of the International Court of Justice: Rep. of the SecretaryGeneral, ๆ ๆ 31-32, U.N. Doc. A/C.5/50/18 (Nov. 2, 1995). See examples of ICJ Judges' service as ad hoc arbitrators in Chiara Giorgetti, The Challenge and Recusal of Judges of the International Court of Justice, in Challenges and Recusals of Judges and Arbitrators in International Courts and Tribunals 3, 11-12 (Chiara Giorgetti ed., 2015) [hereinafter Giorgetti, Judges of the ICJ].

481 U.N. Secretary-General, supra note 480, ๆ 32; Philippe Couvreur, Article 16, in The Statute of the International Court of Justice: A Commentary 357, ๆ 14 and 22 (Andreas Zimmermann et al. eds., 2nd ed. 2012) [hereinafter Couvreur, Article 16].

482 Couvreur, Article 16, supra note 481, ๆ 925 and 34.

483 U.n. Secretary-General, supra note 480, ๆ 31. See also Couvreur, Article 16, supra note 481, I 30. 
Whether or not Article 17 para. 2 ICJ-Statute is exhaustive or should also apply to judges who have other relevant past professional experience, or who have previously publicly voiced their opinions on the subject-matter of a dispute was at the center of disqualification requests in three ICJ cases. ${ }^{484}$ All three requests were dismissed, indicating that Article 17 para. 2 ICJ-Statute is considered to be exhaustive. ${ }^{485}$

By virtue of Article 31 para. 6 ICJ-Statute, ad hoc judges are subject to some of the same requirements of independence and impartiality as members of the Court. In particular, they must make the same solemn declaration on the impartial exercise of their function, they must be independent, and they may not previously have taken part in the decision of the relevant case in any function. ${ }^{486}$

To clarify the application of those rules to specific situations, Practice Directions VII and VIII deal with the admissibility of ad hoc judges' dual roles as adjudicators and as legal advisors in cases before the ICJ. ${ }^{487}$

Practice Direction VII stipulates the incompatibility of the role as an ad hoc judge in one case, and as an agent, counsel or advocate in another case. ${ }^{488}$

484 South West Africa, Order of 18 March 1965, I.C.J. Reports 1965 [hereinafter South West Africa Cases]; Request for the removal of President Sir Muhammad Zafrulla Khan, Judge Padilla Nervo, and Judge Morozov, Legal Consequences for States of the Continued Presence of South Africa in Namibia (South West Africa) notwithstanding Security Council Resolution 276 (1970), Orders No. 1-3 of 26 January 1971, I.C.J. Reports 1971 [hereinafter Namibia (South West Africa)]; Legal Consequences of the Construction of a Wall in the Occupied Palestinian Territory, Order of 30 January 2004, I.C.J. Reports 2004 [hereinafter Construction of a Wall].

485 For details on the disqualification requests, see infra Part 1.2 C.

486 See ICJ-Statute art. 31, para. 6. See also Kooijmans, supra note 128, ๆ 6 ("It would ... be improper to see a judge $a d$ hoc as a representative of the State which appointed him. Once appointed, he or she is completely independent and bound by his or her solemn declaration, just as his or her regular colleagues are.").

487 Practice Direction VII, Feb. 7, 2002, I.C.J. Acts \& Docs. 165 [hereinafter Practice Direction VII]; Practice Direction viII, Feb. 7, 2002, I.C.J. Acts \& Docs. 165 [hereinafter Practice Direction VIII]. The ICJ has been adopting Practice Directions since October 2001. These directions are additional to the ICJ Rules, and provide guidance on procedural matters to States.

488 Philippe Couvreur, Article 17, in The Statute of the Inte rnational Court of JusTiCE: A CommentaRY 372, ๆ 17 (Andreas Zimmermann et al. eds., 2nd ed. 2012) [hereinafter Couvreur, Article 17] (clarifying that Practice Direction vir was adopted to put an end to a "previously observed practice, which ... consisted in acting simultaneously as judge $a d$ 
Parties shall therefore neither nominate persons as ad hoc judges, who are acting as legal advisors in another case, nor shall they instruct an ad hoc judge in another case with their representation. The roles are not only mutually exclusive when exercised simultaneously, but also successively, when the person has acted in the other role in the three years preceding the date of the nomination.

Practice Direction VIII is a counterpart of Practice Direction VII, and prohibits the designation as a legal representative (agent, counsel or advocate) of any person who has in the past three years been a Member of the Court, an ad hoc judge, a Registrar, a Deputy-Registrar or a higher official (principal legal secretary, first secretary or secretary) of the Court. ${ }^{489}$

It is noteworthy that Practice Directions VII and VIII are not restricted to the service in related cases, or in cases in which the facts, the law or the parties overlap. The simultaneous or (recently) sequential exercise of the two roles per $s e$ is considered to be inappropriate. Despite these strict provisions, the pool of individuals qualified enough to act as ad hoc judges has not become so small as to pose a problem to the functioning of the ICJ, as had been feared. ${ }^{490}$ The effect on the pool of ad hoc judges might however be different if the ICJ's caseload was higher, and if the Practice Directions were binding and enforceable, which is a contentious issue. ${ }^{491}$

\section{B Removal of ICJ Judges}

With regard to the consequences of a judge's lack of independence or impartiality, or of a contravention against the more specific provisions on (relative or

hoc in one case ... and as counsel in another."); Kooijmans, supra note 128, \ 19 ("This new directive reflects the need to create a certain distance between the bench and the bar.").

489 See Sir Arthur Watts, New Practice Directions of the International Court of Justice, 1 L. \& Prac. Int'L. Cts. \& Tribunals 247, 252-253 (2002); Bernasconi-Osterwalder, Johnson, and Marshall, supra note 32 , at 36 .

490 Watts, supra note 489, at 254; Couvreur, Article 17, supra note 488, 9 17. Inferences for the ICSID system should however not be made insouciantly, since ICJ and investor-State arbitration proceedings differ in important respects. See Bernasconi-Osterwalder, Johnson, and Marshall, supra note 32 , at 37.

491 Watts, supra note 489, at 255; Bernasconi-Osterwalder, Johnson, and Marshall, supra note 32, at 37; Stefan Talmon, Article 43, in The Statute of the International Court of Justice: A COMmentary 1088, 1096 (Andreas Zimmermann et al. eds., 2nd ed. 2012) ("more likely recommendations or guidelines than binding commands"); SERENA Forlati, The International Court of Justice: An Arbitral Tribunal or a JuDiCial Body? 27 (2014) (not binding, but Rules of Court prevail); Arman SARVARIAN, 
absolute ${ }^{492}$ ) incompatibility, it is important to distinguish the disqualification of a judge in a specific case from a judge's dismissal from the bench.

Decisions on the dismissal of members of the ICJ from the bench are an absolute ultima ratio, and are taken by the Court en banc and by unanimous vote. The dismissal of a judge is therefore only possible if all members of the Court (excluding the respective judge) agree thereon. ${ }^{493}$ Substantively, a dismissal from the bench requires the judge to have "ceased to fulfill the required conditions" 494 to serve - a very high threshold, which would require a grave conflict to effectively incapacitate the relevant judge. ${ }^{495}$ The deliberations on the dismissal are confidential, ${ }^{496}$ and no cases in which an ICJ judge was dismissed are reported. ${ }^{497}$

A disqualification, on the other hand, only affects a judge's decision-making function in a specific case, and is therefore subject to a lower threshold. If a judge refuses to recuse him- or herself upon notice by the President of the Court that "for some special reason ... [the Member] should not sit in a particular case,"498 the Court en banc (but without the challenged judge) shall decide on his or her disqualification. ${ }^{499}$ The parties to the proceeding are authorized to file disqualification requests by virtue of Article 34 para. 2 ICJ Rules.

\section{Case Law}

The grounds for a disqualification are narrowly limited to breaches of Articles 16 or 17 ICJ-Statute. These provisions were found to be exhaustive in the South

Professional Ethics at the International Bar 92 (2013) (not binding, but treated in practice as if obligatory).

492 See Giorgetti, Judges of the ICJ, supra note 480 , at 5-9.

493 ICJ-Statute art. 18, para. 1; ICJ Rules art. 6. See Markus Buechel, The Independence of International Arbitrators, in The Culture of Judicial Independence. Conceptual Foundations and Practical Challenges 243, 248 (Shimon Shetreet \& Christopher Forsyth eds., 2012); David Anderson \& Samuel Wordsworth, Article 18, in The Statute of the International Court of Justice: A Commentary $386, \boldsymbol{q} 18$ (Andreas Zimmermann et al. eds., 2nd ed. 2012).

494 ICJ-Statute art. 18, para. 1.

495 Giorgetti, Judges of the ICJ, supra note 480, at 12; Anderson and Wordsworth, supra note 493, If 10 (requiring "some statement, action or course of conduct [which] is egregious.").

496 ICJ Rules art. 6.

497 Anderson and Wordsworth, supra note 493, ๆ18; Giorgetti, Judges of the ICJ, supra note 480 , at 12.

498 ICJ-Statute art. 24, para. 2.

499 ICJ-Statute art. 16, para. 2; art. 17, para. 3; and art. 24, para. 3. 
West Africa Cases, ${ }^{500}$ in Namibia (South West Africa), 501 and in Construction of a Wall.502

The decision in Construction of a Wall is of particular interest, because of the famous dissent of Judge Buergenthal in this case. The government of Israel requested the removal of Judge Elaraby, ${ }^{503}$ arguing that the judge had previously been "actively engaged in opposition to Israel including on matters which go directly to aspects of the question now before the Court." ${ }^{\text {504 }}$ More concretely,

500 The details of the request for removal and the reasons for the Court's dismissal are not discernible in the decision (South West Africa Cases, at 3). According to Namibia (South West Africa), at 16, para. 9, the request for removal was based on the Judge's previous role as a government official, and on statements made in this capacity ("[T]he Court found no reason to depart in the present advisory proceedings from the decision adopted by the Court ... in the South West Africa cases ... after hearing the same contentions as have now been advanced by the Government of South Africa." (emphasis added)). See also Couvreur, Article 17, supra note 488, \19.

501 In Namibia (South West Africa), the government of South Africa objected to the participation of three members of the Court in the proceedings. The ICJ Judges had formerly participated, as representatives of their governments, in United Nations organs which were dealing with matters concerning South West Africa, and had made statements in this context. The Court held that there was no reason to depart from its decision in the South West Africa Cases, and concluded that such activities did not fall within the scope of application of ICJ-Statute art. 17, para. 2. See Namibia (South West Africa) at 16, para. 9 (referencing precedents of the ICJ as well as of the Permanent Court of International Justice (PCIJ), in which judges were allowed to remain on the Court, although they had taken part in the formulation of texts the Court was asked to interpret). See also Couvreur, Article 17, supra note 488, ๆ 19.

502 These three decisions are the only instances in which parties attempted to have ICJ Judges disqualified. The scarcity of disqualification requests against ICJ Judges can possibly be explained by the comparatively large number of recusals. It appears that ICJ Judges have a tendency to interpret ICJ-Statute art. 17, para. 2 rather strictly, and to recuse themselves voluntarily when the provision applies in a particular case. See Couvreur, Article 17, supra note 488, ๆ 18 (" [w] henever a member of the Court, has, before taking office, acted as agent, counsel or advocate of one of the parties to a case, he has always disqualified himself from the case without this ever becoming an issue. The same has applied to any judge taking part in arbitration proceedings which have become the subject of proceedings before the Court."); Giorgetti, Judges of the ICJ, supra note 480, at 6-7 and 13-17 tbl.1. See also Application of the Convention on the Prevention and Punishment of the Crime of Genocide (Bosn.\& Herz. v. Serb. \& Montenegro), Verbatim Record, 6 (Apr. 29, 1996, 10 a.m.), http://www.icj-cij.org/docket/files/91/5105.pdf (recusals of Judge Higgins and Judge Fleischhauer). But see, with regard to ICJ ad hoc judges, Couvreur, Article 17, supra note 488, ๆ 20.

503 Construction of a Wall, 3-10.

504 Construction of a Wall, 3-10, para. 5 . 
Judge Elaraby had participated in the Tenth Emergency Special Session of the General Assembly, and had acted as the principal Legal Adviser to the Egyptian Ministry of Foreign Affairs (1976-1978 and 1983-1987), and as a Legal Adviser to the Egyptian Delegation to the Camp David Middle East Peace Conference of 1978. He had further been involved in initiatives following the signing of the Israel-Egypt Peace Treaty in 1979, concerning the establishment of autonomy in the West Bank and the Gaza Strip, and had given an interview to an Egyptian newspaper in August 2001 (two months before his election to the ICJ, when he was no longer his country's diplomatic representative), wherein he voiced his views on questions concerning Israel. According to Israel, Judge Elaraby's previous professional involvements, as well as the interview, warranted his removal from the Court.

Referencing Namibia (South West Africa), the ICJ dismissed the request in a near-unanimous vote. ${ }^{505}$ It held that the activities Judge Elaraby performed as a diplomatic representative, mostly long before the question at the center of the dispute arose, and the newspaper interview he gave, were not sufficiently closely related to the dispute at hand to fall under Article 17 para. 2 ICJ-Statute. Judge Elaraby had not "previously taken part" in the case in any capacity. ${ }^{506}$

Judge Buergenthal's dissent in Construction of a Wall stressed that he did not doubt the personal integrity of Judge Elaraby, but that the views he had expressed in the newspaper interview could be perceived as a prejudgment of the question submitted to the Court, and of the disputing parties' respective arguments. The interview created an appearance of bias which justified Judge Elaraby's removal from the case. ${ }^{507}$ Judge Buergenthal conceded that formally, the language of Article 17 para. 2 ICJ-Statute did not cover the specific situation, but argued that the provision was not exhaustive. It only covered the "most egregious violations of judicial ethics," while reflecting "much broader conceptions of justice and fairness that must be observed by courts of law":

Judicial ethics are not matters strictly of hard and fast rules - I doubt that they can ever be exhaustively defined - they are matters of perception and of sensibility to appearances that courts must continuously keep in mind to preserve their legitimacy. ${ }^{508}$

505 The decision was taken with 13 votes to one.

506 Construction of a Wall, para. 8 .

507 Construction of a Wall, para. 13 .

508 Construction of a Wall, 3-10, at 9, para. 10. This broad interpretation of ICJ-Statute art. 17, para. 2 explicitly refers to judicial ethics, i.e. the independence and impartiality of elected judges, who are institutionally insulated as members of a permanent international 
This dissent raises important questions about the appropriate standard of independence and impartiality of ICJ Judges, but does not alter the fact that the ICJ's case law indicates a formalistic and narrow construction of Article 17 para. 2 ICJ-Statute: Public statements of a Judge which might indicate a prejudgment of the issues at hand, but which were made in a function other than those listed in Article 17 para. 2 ICJ-Statute, including in a prior diplomatic function, as a government representative, or at the United Nations, do not lead to a disqualification. ${ }^{509}$

Apart from the disqualification requests in the above-referenced three cases, which were based on the judges' prior functions, the more abstract issue of national bias is usually at the center of the discussion about the independence of ICJ Judges (including ad hoc judges). The ICJ is frequently criticized for lacking political neutrality, ${ }^{510}$ despite various provisions which aim at an equitable geographic distribution of the ICJ Judges ${ }^{511}$ and at reducing the effect of member States' political considerations on the election process. ${ }^{512}$ This criticism is closely connected to an apprehension of judicial nationalism, ${ }^{513}$ i.e. national judges' bias in favor of their home country. ${ }^{514}$ Even ad hoc judges mainly elicit concerns of national bias in favor of their appointing State. ${ }^{515}$ In light of their

dispute resolution body (see Giorgetti, Judges of the ICJ, supra note 480, at 3). Nevertheless, Judge Buergenthal's dissent is frequently cited in the investment arbitration context (Rubins and Lauterburg, supra note 32, at 174; Markert, supra note 21, at 174; Barton Legum, Investor-State Arbitrator Disqualified for Pre-Appointment Statements on Challenged Measures, 21 ARB. INT'L. 241, 242 (2005)), and Judge Buergenthal himself has transposed his views to ICSID arbitrators (Buergenthal, supra note 478 , at 498).

509 Giorgetti, Judges of the ICJ, supra note 480, at 21.

510 Ruth Mackenzie \& Philippe Sands, International Courts and Tribunals and the Independence of the International Judge, 44 HARV. INT'L. L.J. 271, 278 (2003). This criticism often revolves around the control of individual seats by powerful countries, in particular by the United States. See Posner and Yoo, Judicial Independence, supra note 119, at 35.

511 ICJ-Statute art. 9. For the distribution of the seats in practice, see Mackenzie and Sands, supra note 510, at 278 (2003); Chiara Giorgetti, The Challenge and Recusal of Judges of the International Court of Justice, in Challenges and Recusals of Judges AND ARBitrators in International Courts and Tribunals 3, 6 n.11 (Chiara Giorgetti ed., 2015).

512 E.g. the interposition of national groups of the PCA in the process of the election of ICJ Judges provided for in ICJ-Statute art. 4, para. 1.

513 See Dannenbaum, supra note 108; Smith, supra note 120.

514 These concerns are not discussed in detail herein, since they are more general, remote and abstract forms of potential bias than the conflicts of interest alleged by challenging parties in the ICSID system.

515 See Suh, supra note 122, at 229-230. This was already a concern when the Statute of the PCIJ was drafted by an Advisory Committee of Jurists in 1920. See PCIJ Advisory 
similarity with arbitrators, it is surprising that other potential risks inherent in party-appointments, such as the preconceived views of such decision-makers, which are known to the appointing party and believed by it to be in its favor, are not discussed at all. Such factors could possibly provide an additional explanation for the striking empirical indication of national judge bias. ${ }^{516}$

\subsection{Dispute Settlement in the World Trade Organization}

In the World Trade Organization (wTO), trade disputes between member States are settled on two levels.

On the first-instance level, ad hoc panels handle the disputes and render reports. They usually consist of three panelists, ${ }^{517}$ which are either jointly appointed by the disputing parties, ${ }^{518}$ or, more often, by the Director-General. ${ }^{519}$ The roster of potential panelists maintained by the Secretariat is only indicative. ${ }^{520}$

Committee of Jurists, Procès-Verbaux of the Proceedings of the Advisory Committee of Jurists, 34th Meeting (July 24, 1920), Annex No. 1, 720-722, available at https://archive.org/ details/procsverbauxofooleaguoft.

516 See Eric A. Posner \& Miguel de Figueiredo, Is the International Court of Justice Biased? 18 (2004).

517 Understanding on Rules and Procedures Governing the Settlement of Disputes art. 6, para. 1 and art. 8, para. 5, Apr. 15, 1994, wTO Agreement, Annex 2, 1869 U.N.T.s. 401 [hereinafter DSU]. To date, the disputing parties have never agreed to a panel composed of five panelists, see Peter Van den Bossche \& Werner Zdouc, The Law and Policy of the World Trade Organization 214 (3rd ed. 2013); Gregory J. Spak \& Ron Kendler, Selection and Recusal in the WTo Dispute Settlement System, in CHALlEng es AND RECUSALS of Judges and ARbitrators in International Courts and Tribunals 164, 165 (Chiara Giorgetti ed., 2015).

518 DSU art. 8, para. 7. The nominations proposed by the Secretariat (DSU art. 8, para. 6) are often rejected by the parties, see VAN DEN Bossche AND Zdouc, supra note 517, at 215-216; Spak and Kendler, supra note 517 , at 166-167.

519 The Director-General is the head of the wто Secretariat. See Agreement Establishing the World Trade Organization art. 6, para. 1, Apr. 15, 1994, 1867 U.N.T.s. 154 [hereinafter wTO Agreement]. Either party may request the Director-General to nominate the panelists if the disputing parties fail to reach an agreement on the nominees within twenty days (DSU art. 8, para. 7). In practice, parties try to stay in control of the nomination for as long as possible, and allow for more time to reach an agreement. Ultimately, however, they are rarely successful, and the Director-General has appointed most panels. VAN DEN Bossche AND ZDouc, supra note 517, at 216; Spak and Kendler, supra note 517, at 167 (listing detailled information on the number of panels composed by the Director-General).

520 DSU art. 8, para. 4. Most first-time panelists were not on this list at the time of their appointment. See VAN DEN BossCHE AND Zdouc, supra note 517, at 216. 
On the second level, panel reports can be appealed before divisions of the Appellate Body $(\mathrm{AB})$, which usually consist of three members. ${ }^{521}$ The AB itself is a standing body of seven individuals who are nationals of different WTO member States, ${ }^{522}$ and who are appointed by the Dispute Settlement Body (DSB $)^{523}$ for staggered four year terms. ${ }^{524}$ The divisions handling individual appeals are selected randomly and unpredictably, on a rotational basis. ${ }^{525}$

The DSB administers the proceedings at all stages, from the appointment of the dispute settlement panel, through the adoption of panel and Appellate Body reports, to the authorization of sanctions in the event of a non-compliance with a judgment. ${ }^{526}$

\section{A Independence and Impartiality Requirements}

When nominating panelists, the parties are free to agree on anyone who fulfils the requirements of Article 8 DSU. In particular, panelists shall:

- be well-qualified individuals with substantial expertise in international trade law or policy; 527

521 DSU art. 17, para. 1; Working Procedures for Appellate Review rule 6, para. 2, Aug. 16, 2010, WT/AB/WP/6 [hereinafter Working Procedures].

522 Appellate Body membership shall be broadly representative of membership in the WTO (DSU art. 17, para. 3). In reality, however, the United States and the European Union have assured seats, as well as an important influence on the candidates from other countries. See Erik Voeten, The Politics of International Judicial Appointments, 9 CHI. J. INT'L. L. 387, 402 (2009).

523 The DSB is an emanation of the wTo's General Council (VAN Den Bossche AND ZDOUC, supra note 517 , at 206.). It is composed of representatives of all wTO member States. See wTo Agreement art. 4, para. 3 and 2.

524 DSU art. 17, para. 1 and 2. Appellate Body members may be reappointed once. The DSB appoints Appellate Body members by consensus, on the recommendation of a selection committee, which in turn selects among candidates nominated by wто Members. See VAN DEN Bossche AND Zdouc, supra note 517, at 232.

525 Working Procedures rule 6, para. 2.

526 DSU art. 2, para. 1. Many of the DSB's key decisions are subject to a reverse or negative consensus requirement: Unless all DSB members unanimously agree not to appoint a panel, not to adopt a report or not to authorize sanctions, the respective action cannot be blocked. See DSU art. 6, para. 1, art. 16, para. 4, art. 17, para. 14, and art. 22, para. 7; VAN DEN Bossche AND Zdouc, supra note 517, at 206.

$5^{27}$ DSU art. 8, para. 1. DSU art. 8, para. 8 explicitly stipulates that member States shall permit their officials to serve as panelists. Apparently, this is not considered to be a potential source of conflict of interests. 
- be independent, from diverse backgrounds, and with a wide spectrum of experience; 528

- not be nationals of one of the disputing parties or a third party, unless otherwise agreed by the parties. ${ }^{529}$

To date, current or retired government trade officials with a background in law have predominantly served as panelists. Academics and private trade law practitioners have also adjudicated a considerable number of disputes. At least half of all panelists have prior experience with serving on a GATT or WTO panel whether this experience is in related cases is unclear. ${ }^{530}$

Appellate Body members must generally be "persons of recognized authority, with demonstrated expertise in law, international trade and the subject matter of the covered agreements generally."531 When deciding appeals as members of an Ав division, they may or may not be nationals of one of the disputing parties. In any event, they must be "unaffiliated with any government," ${ }^{, 532}$ and independent. ${ }^{533}$ If the participation of an AB member in a particular division would create a direct or indirect conflict of interest in a specific case, that member must step down. ${ }^{534}$

528 DSU art. 8, para. 2. DSU art. 8, para. 9 specifies the requirement of independence by stipulating that "[p]anelists shall serve in their individual capacities and not as government representatives, nor as representatives of any organization. Members shall therefore not give them instructions nor seek to influence them as individuals with regard to matters before a panel." DSU art. 8, para. 10 encourages the appointment of panelists from developing countries.

529 DSU art. 8, para. 3. This contrasts with the institution of the ICJ ad hoc judge. The fact that parties in WTO disputes have in some cases, but not usually agreed to national panelists (e.g. US - Zeroing (EC) (2006), see VAN DEN Bossche AND ZDouc, supra note 517, at 215), could be understood to imply that the parties' distrust towards a national judge of their counterparty is more important than their own urge to have someone who will understand their national law, or promote their right to be heard, on the panel. The different prioritization could however also be explained with the existence of appellate review under the wTO DSU. Even if the grounds for such review are limited, the assurance of a certain degree of coherence and consistency and the feeling of control thereby afforded to the parties may effectively substitute their wish for control by appointing a national. VAN DEN Bossche AND Zdouc, supra note 517, at 215.

531 DSU art. 17, para. 3 .

532 DSU art. 17, para. 3.

533 Working Procedures rule 2, para. 2 and 3 (prohibiting Appellate Body members from accepting or seeking instructions from anyone, and from pursuing any employment or other professional activity which might be at odds with their duties and responsibilities).

534 DSU art. 17, para. 3 ("They shall not participate in the consideration of any disputes that would create a direct or indirect conflict of interest."). 
Panelists and Appellate Body members are subject to the WTo's Rules of Conduct, ${ }^{535}$ which require them to be independent and impartial and to avoid direct or indirect conflicts of interest. ${ }^{536}$ They must disclose any existing or developing interest, relationship or matter which they are (or could reasonably be expected to be) aware of and which "is likely to affect, or give rise to justifiable doubts" as to their independence or impartiality. ${ }^{537}$

Very exceptionally, panelists have voluntarily resigned as a consequence of alleged conflicts of interest. ${ }^{538}$ In Turkey - Restrictions on Imports of Textile and Clothing Products (DS34) ("Turkey - Textiles"), a panelist withdrew after one of the parties complained that an unpublished conference paper he had previously authored on the subject-matter was relevant in the proceeding. ${ }^{539}$ Appellate Body Members have apparently recused themselves on several occasions, but without a formal challenge proceeding being initiated. ${ }^{540}$ Due to the confidentiality of Appellate Body operations, no detailed information about such withdrawals is available. ${ }^{541}$

\section{B Challenge of Panelists and Members of the Appellate Body}

Disputing parties can challenge panelists and Appellate Body members based on material violations of their obligations of independence and impartiality,

535 Rules of Conduct for the Understanding on Rules and Procedures Governing the Settlement of Disputes Section IV, Working Procedures, Annex 2, Dec. 11, 1996, WT/DSB/RC/1 [hereinafter Rules of Conduct].

536 Rules of Conduct Section II, para. 1.

537 Rules of Conduct Section III, para. 1. This disclosure standard is similar to that of the ICSID and UnCitral Arbitration Rules. Annex 2 to the Rules of Conduct illustratively lists information which must be disclosed, such as financial, business, property, professional, employment, and family interests as well as statements of personal opinion on issues relevant to the dispute. These examples are reminiscent of the IвA Guidelines' Orange and Red Lists (infra Part 3.2 B.). See also Rubins and Lauterburg, supra note 32, at 166.

538 VAN DEN Bossche AND Zdouc, supra note 517, at 217; Spak and Kendler, supra note 517, at 164 and $175^{-176}$ (specifying that all withdrawals but one "were the result of unrelated concerns, such as the panelists' health or promotion to other positions in the WTO").

539 Panel Report, Turkey - Restrictions on Imports of Textile and Clothing Products, ๆ 1 1.51.6, WT/DS34/R (May 31, 1999); see Spak and Kendler, supra note 517, at 175.

540 Yves Renouf, Challenges in Applying Codes of Ethics in a Small Professional Community: The Example of the WTO Rules of Conduct for the Understanding on Rules and Procedures Governing the Settlement of Disputes, in Accountability, Investigation and Due Process in International Organizations 111, 127 (Chris de Cooker ed., 2005); Spak and Kendler, supra note 517, at 177 .

Spak and Kendler, supra note 517 , at 178. 
and of their duty to avoid conflicts of interest, which may impair the integrity, impartiality or confidentiality of the dispute settlement mechanism. ${ }^{542}$ In the case of panel members, such challenges are decided by the chair of the DSB, in consultation with the Director-General and the chairs of the relevant wTO bodies; if the removal of an Appellate Body member is requested, the Appellate Body itself will adjudicate the request. ${ }^{543}$

The burden of proof for a successful challenge of a panelist or Appellate Body member appears to be rather high: ${ }^{54}$ The Rules of Conduct require the submission of "evidence of a material violation" of the Rules of Conduct in a written statement specifying the relevant facts and circumstances. ${ }^{545}$ The concrete meaning of the "material violation" threshold, however, is unclear. ${ }^{546}$ To date, no material violation of the Rules of Conduct has been found to have occurred. ${ }^{547}$

So far, challenges have been very rare in the wTо system. ${ }^{548}$ Given the similarities among Wто panelists and ICSID arbitrators, this is surprising: Like

542 Rules of Conduct Section viII, para. 1. If the disputing parties agree that a material violation has occurred, the disqualification should be confirmed, see Rules of Conduct Section VIII, para. 8.

543 Rules of Conduct Section viII, para. 8 and Section viII, para. 16. See also Gabrielle Zoe Marceau, Rules on Ethics for the New World Trade Organization Dispute Settlement Mechanism: The Rules of Conduct for the Understanding on Rules and Procedures Governing the Settlement of Disputes, 32 J. World Trade 57, 67 (1998); Spak and Kendler, supra note 517, at $173^{-178}$. Objections to panelists which are addressed to the panel itself, instead of the chair of the DSB, are not appraised: See Guatemala - Cement II (Panel Report, Guatemala - Definitive Anti-Dumping Measures on Grey Portland Cement from Mexico, WT/DS156/R (Oct. 24, 2000)), If 4.3 (Guatemala raised concerns that the panelist, as a result of his previous service on a panel dealing with the same issue, would have preconceived positions) and $\uparrow 8.11$.

544 Marceau, supra note 543, at 85. Contra Rubins and Lauterburg, supra note 32, at 167 (stating that the standard is less stringent than that contained in the IвA Rules of Ethics for International Arbitrators); Nadakavukaren Schefer, supra note 82, at 237 (stating that the standard is less stringent than arbitration rules).

545 Rules of Conduct Section virI, para. 1 and 2 (clarifying that a failure to disclose by itself is not a sufficient ground for disqualification). See also Spak and Kendler, supra note 517, at 172.

546 Since the deliberations on the challenged member's dismissal are confidential (Rules of Conduct Section VIII, para. 20), the interpretations of the threshold by the chair of the DSB and the AB are unknown.

547 Spak and Kendler, supra note 517, at 174; VAN DEN BossCHE AND ZDOUC, supra note 517, at 217 .

548 Rubins and Lauterburg, supra note 32, at 167; Spak and Kendler, supra note 517, at 165 . 
ICSID arbitrators, WTO panelists and Appellate Body members often decide disputes which affect public interests, and in which the stakes are high. Like the appointment of ICSID arbitrators, the selection of WTO panelists is partydriven, and might therefore tempt the parties to try to manipulate the outcome of a proceeding, by selecting a partisan decision-maker.

The independence and impartiality of WTO decision-makers and the scarcity of disqualification requests in the WTO system have received very little doctrinal attention. ${ }^{549}$ The few scholars who have broached the subject have mainly argued that there might be fewer challenges in the wTо system because the parties are required to agree on the panelists, ${ }^{550}$ and that this selection mechanism allows parties to address ethical concerns from the outset, instead of challenging the decision-makers later on. ${ }^{551}$

This circumstance on its own, however, cannot explain the virtual inexistence of challenges in the WTO system. In fact, due to the difficulty of the parties' agreement on the decision-makers, the panel members are more often appointed by the Director-General, ${ }^{552}$ and hence without any input from the parties at all, except for their ability to reject undesirable candidates..$^{553}$ In these instances, it is possibly the very absence of party influence which diminishes the parties' reciprocal mistrust, and which reduces the incidence of challenges. Thus, it seems that the combination of a party-driven appointment mechanism, in which the parties are required to make a joint effort, on the one hand, and a subsidiary institutional appointment mechanism, on the other hand, instill confidence in the panelists' reliability for independent and impartial judgment in the parties.

Spak and Kendler mention several additional factors which might help explain the lack of challenges in the Wто system. ${ }^{554}$ In particular, and interestingly, they argue that circumstances which are widely held to increase the risk of dependence and bias in ICSID arbitration - such as the small and tightly knit community, and the interchanging roles of its members - reduce the likelihood of challenges in the wTO system. ${ }^{555}$ If this were indeed the case, however, it would seem to indicate that the actors in the Wто system refrain from filing

549 See Nadakavukaren Schefer, supra note 82, at 234.

$55^{\circ}$ Rubins and Lauterburg, supra note 32, at 167; Spak and Kendler, supra note 517, at 178-180.

$55^{1}$ Spak and Kendler, supra note 517 , at 178 and 180.

$55^{2}$ See VAN DEN Bossche AND Zdouc, supra note 517, at 216; Spak and Kendler, supra note 517 , at 167 .

553 DSU art. 8, para. 6; see Spak and Kendler, supra note 517, at 178.

554 Spak and Kendler, supra note 517 , at 178-181.

555 Id. at 181. 
challenges against each other in order to preserve their own and each other's reputation, and not because there are no grounds for such challenges. ${ }^{556}$

A more convincing explanation for the lack of panelist challenges (but not Appellate Body members) is the parties' possibility of appealing a panel report: Given the possibility of appealing a flawed decision by the panelists, the parties are less dependent on averting an unfavorable outcome by filing arbitrator challenges. 557

\subsection{Contextualization and Conclusion}

The most remarkable conclusion to be drawn from the above analysis of the requirements of independence and impartiality and the challenge proceedings before the ICJ and in the WTO Dispute Settlement Mechanism is that the scarcity of available challenge case law in both systems leads to substantial uncertainty regarding the handling of potential bias in practice.

On an abstract level, the relevant provisions applicable to ICJ Judges and Wто decision-makers are generally similar: all decision-makers are required to be independent and impartial, and to avoid conflicts of interest. The differences between the requirements on a more detailed level, however, are striking.

Ad hoc judges at the ICJ can effectively only be challenged based on their previous involvement in the same matter, as exhaustively regulated in Article 17 para. 2 ICJ-Statute. While this rule is crucial, it is also quite elementary, and leaves an entire category of potential conflict situations untouched: Whenever an ad hoc judge has dealt with the specific matter before, but in a function other than those listed in Article 17 para. 2 ICJ-Statute, or where he or she has previously been confronted with the decisive questions in the dispute, but in another case, a disqualification request will not succeed. ${ }^{558}$ The simultaneous role as a counsel in another dispute resolution mechanism, and the ability to make decisions which are prejudicial to that case in the function of an ad hoc judge, are not covered by ICJ-Statute Article 17 para. 2 either.

Beyond Article 17 para. 2 ICJ-Statute, ad hoc judges are not covered by the institutional protections ${ }^{559}$ applicable to ICJ Judges. In particular, while

556 See also Nadakavukaren Schefer, supra note 82, at 238.

557 Spak and Kendler, supra note 517 , at 181.

$55^{8}$ This limitation on challenges which are based on the successive involvement with the same legal or factual questions, in different roles, also applies to members of the ICJ.

559 ICJ-Statute art. 16, para. 1 and art. 17, para. 1, also referred to as absolute or functional incompatibilities (Giorgetti, Judges of the ICJ, supra note 480, at 7-9.). 
Practice Direction viI extends the incompatibility provisions of Article 17 para. 1 ICJ-Statute to ad hoc judges, and even provides for a three year vesting period, this is a mere recommendation, which is not enforceable.

Although the ICJ-Statute requires independence and impartiality from all judges, the existing challenge case law ${ }^{560}$ strongly implies that a general allegation of a lack of independence or impartiality is not a valid basis for a disqualification request. Accordingly, it appears that challenges based on an ad hoc judge's connection to a participant in the proceeding (including, in extremis, an attorney-client relationship between an ad hoc judge and his or her appointing party, in another matter) or to an adverse third party would be dismissed. An ad hoc judge's role as a public servant or as an employee of the appointing party appears not to be a sufficient basis for a challenge, either. More indirect connections, such as the familiarity of an ad hoc judge with a legal representative of a party, can impair the judge's free decision-making, but will not suffice for a disqualification.

Finally, role switching and repeat appointments as particularly important conflict categories in the ICSID system are not covered by enforceable independence and impartiality related provisions of the ICJ-Statute or ICJ Rules, and could therefore theoretically be an issue. However, these conflict categories appear not to be problematic in the context of the ICJ, since ad hoc judges are usually only appointed once. ${ }^{561}$

The rules concerning the independence and impartiality of WTO panelists, in contrast, are very general and do not limit challenges to particular conflict categories. Any material violation of the panelists' obligation of independence or impartiality which may impair the integrity or impartiality of the dispute settlement mechanism can serve as a basis for a disqualification request. The challenging party must then, however, provide proof of such a material violation.

The interpretation of this threshold is anything but clear. In fact, the questions arising from this terminology are very similar to the discussions in the context of the ICSID challenge threshold: How does a challenging party prove a material violation of independence or impartiality? Is it required to provide evidence for the decision-maker's state of mind, or is it allowed to draw inferences from his or her behavior? Is the burden imposed by the requirement to prove a "material violation" heavier than if a simple, ordinary, or plain violation were required? Finally, the Rules of Conduct require that the violation "may

56o Supra Part 1.2 C.

561 Bernasconi-Osterwalder, Johnson, and Marshall, supra note 32, at 37. 
impair the integrity [or] impartiality ... of the dispute settlement mechanism." This could either be read as a loosening of the challenge standard, or as limiting language: On the one hand, the reference to the system's integrity implies the importance of appearances and perceived legitimacy; on the other hand, remote connections or vague preconceptions which might well affect the outcome of a particular case, are unlikely to taint the legitimacy of the entire dispute settlement mechanism.

For lack of existing case law, as well as an academic discussion of these questions, the answers to these questions are even less clear than in the ICSID system.

\section{International Commercial Arbitration}

\subsection{Relevance}

The delimitation of independence and impartiality in international commercial arbitration is instructive for the ICSID system because the two arbitration systems are based on the same structural design. ${ }^{562}$ In particular, investment and commercial arbitration share the central feature of ad hoc party-appointments. In both systems, the parties autonomously select the decision-makers who will adjudicate their dispute, without regard to any roster or panel of approved arbitrators. ${ }^{563}$ In international commercial arbitration as in investor-State arbitration, party-appointments are portrayed as one of the main advantages of the arbitration system, because they should guarantee that the arbitrators have the requisite legal knowledge and practical expertise in the

562 Gus Van Harten \& Martin Loughlin, Investment Treaty Arbitration as a Species of Global Administrative Law, 17 EUR. J. INT'L. L., 139 (2006) (explaining that commercial arbitration rules served as a model for the structural design of ICSID arbitration); DE BRABANDERE, supra note 455 , at 2 (considering investment arbitration to be "derived from" commercial arbitration); Wouters and Hachez, supra note 19, at 618 (considering ICSID arbitration to be a form of commercial arbitration, and not a sui generis mechanism which procedurally emulates commercial arbiration); Van Harten, Investment Treaty ArbitraTion, supra note 7, at 124. But see Gabrielle Kaufmann-Kohler, Foreword, in Antonio R. PARRA, The History of icsid (2012) ("ICSID arbitration procedure was not based on commercial arbitration. The drafters relied on public international law instruments such as the Statute and Rules of the International Court of Justice (ICJ) or the Model Rules on Arbitral Procedure of the International Law Commission (ILC).").

563 Van Harten and Loughlin, supra note 562, at 139; SCHWARTZ AND DerAINs, supra note 87 , at 114 . 
field at issue. ${ }^{564}$ The parties, it is argued, know best what qualifications are required to understand their positions and the subject-matter of their dispute. Another argument brought forward in support of party-appointments is that they enhance the parties' identification with and acceptance of the arbitrators' decision, and thereby allow for the finality of arbitration awards. Thus, the tension between party-appointments and the requisite independence and impartiality of arbitrators described in the context of ICSID arbitration ${ }^{565}$ is also present in commercial arbitration. This Part analyzes how select commercial arbitration rules and case law deal with the tension, and how independence and impartiality are delimited so as to facilitate the legitimate interests pursued by the system of party-appointments, while preventing dependence and bias.

Finality has a central role in both investment and commercial arbitration: Neither system provides for an appellate mechanism, and the grounds for annulment are very limited. ${ }^{566}$ This is further reinforced in the self-contained ICSID regime, where external (domestic) review mechanisms do not enter the picture at the enforcement stage. 567 The driving forces behind finality, however, appear to differ in the two systems: In commercial arbitration, finality is primarily associated with the reliable and efficient dispute settlement function of the mechanism. The (speedy) resolution of disputes is the main goal of commercial arbitration, even more important than substantive justice. ${ }^{568}$ This focus on efficiency and liberty, rather than justice, entails a high degree of party autonomy, ${ }^{569}$ which is sometimes even held to extend to the requirement of arbitrators' independence and impartiality. ${ }^{570}$ In the ICSID system, on the other hand, finality and the full decoupling from domestic judicial processes serve the purpose of de-politicization, ${ }^{571}$ rather than a speedy and efficient

\footnotetext{
564 Wouters and Hachez, supra note 19, at 620.

$5^{65}$ See supra Chapter 1, Part 2.2.

566 See ICsid Convention art. 53, para. 1. See also Paulsson, The IdeA, supra note 22, at 1.

567 See Schreuer, Dynamic Evolution, supra note 5, at 18.

568 Paulsson, The IdeA, supra note 22, at 17.

569 Id. at 2.

570 See Nordström-Janzon and Nordström-Lehtinen v. the Netherlands, Ec HR 28101/95 (Nov. 27,1996 ) (by submitting to arbitration, the disputing parties waive their right to individual and impartial decision-makers; such a waiver is only restrained by domestic law rules on the annulment of arbitral awards, which guarantee a minimum degree of independence and impartiality). This reasoning does not apply in the self-contained ICsID system. See, e.g., LutTRELL, supra note 31, at 214.
}

571 Broches, supra note 4, at 343. But see Wouters and Hachez, supra note 19, at 623 (arguing that the expedient, final and apolitical settlement of disputes is the main appeal of arbitration in both the commercial and in the investment arbitration context). 
(but not primarily just) resolution of the dispute. Procedural justice and the perceived fairness of the proceeding are the very raisons d'être of investor-State arbitration under the ICSID Convention, and determinative for its acceptance as a legitimate dispute resolution mechanism. ${ }^{572}$ As a consequence, the qualities of party-appointed arbitrators which legitimize the finality of ICSID awards are arguably different from those of commercial arbitrators. Independence and impartiality, in particular, are essential traits of ICSID arbitrators, which cannot be waived by the disputing parties. Accordingly, the priority given to arbitrators' independence and impartiality under the commercial arbitration rules examined below should only be understood as a minimum standard - a floor, and not a ceiling - for ICSID arbitration.

This stance is also supported by other key differences between commercial and investment arbitration. In particular, the more frequent involvement of public interests in the investment context calls for increased attention to the perceived legitimacy of the system. ${ }^{573}$ This is even more crucial in the light of the amounts in dispute which are often higher than in commercial arbitration. ${ }^{574}$ The small size of the investment arbitration community ${ }^{575}$ and the relatively repetitive legal issues at the center of investment disputes ${ }^{576}$ increase the likelihood of conflicts of interest, and call for a particularly strict approach to the issue of independence and impartiality. The same is true for the character of the ICSID framework as a self-contained regime, which deprives the parties of the usual possibility of questioning the arbitrators' independence

572 Paulsson, The IDEA, supra note 22, at 17; Franck, Integrating Investment Treaty Conflict, supra note 22, at 214-215; Kee, supra note 22, at 195 .

573 Rivkin, supra note 18 , at 341 ("Investor-state arbitration is of course an entirely different animal than traditional commercial arbitration since these disputes involve sovereign states rather than just private parties. There is simply much more at stake here. In this context, we are concerned not only about certainty but also about legitimacy. We care far more about tribunals 'getting it right' because the awards involve public goods and public money."). See also Horvath and Berzero, supra note 37, at 5; DAE LE, supra note 51, ๆ 5-107.

574 Rivkin, supra note 18, at 352. But see Caron, Investor State Arbitration, supra note 23, at 514 (pointing out that the differences between commercial and investment arbitration are not always as accentuated in practice as is argued in the doctrine). Commercial arbitration cases can also involve issues that are in the public interest. For example, investment disputes which are not governed by the ICSID Convention are often subject to the commercial arbitration rules examined in this Chapter. On the other hand, investment arbitration cases sometimes concern questions unrelated to public policy, and involving relatively modest claims for damages.

575 Horvath and Berzero, supra note 37 , at 5 .

576 Horvath and Berzero, supra note 37, at 5; Paulsson, The IdeA, supra note 22, at 151; BLACKABY ET AL., supra note 9o, \ 4.128; contra Caron, Caron, Investor State Arbitration, supra note 23 , at 517 . 
and impartiality at the execution stage. This renders the availability of an effective mechanism to ensure unbiased decision-making during the proceedings all the more important. ${ }^{577}$ On balance, it appears proper to expect the standard of independence and impartiality applied in investment arbitration to provide at least an equivalent level of protection to the parties as the standards applied in commercial arbitration.

The commercial arbitration rules examined in this study ${ }^{578}$ - i.e., the UNCITRAL, SCC and ICC Arbitration Rules - were chosen based on their wide acceptance and frequent use in investment arbitration. ${ }^{579}$ The availability of challenge decisions under the SCC and ICC Arbitration Rules, however, is limited: Decisions are generally unreasoned and unpublished, ${ }^{580}$ and have only selectively been reported in academic publications. As a consequence, the documented outcomes of challenges are not necessarily representative, and the rationales of particular challenge decisions are unknown. Acknowledging this limitation, this book nevertheless seeks to identify trends in the assessment of particular categories of potential conflict of interest, by working with the available resources. For this purpose, the reported challenge decisions are grouped in the categories established in Chapter 2, Part 2. Where reasoned

577 Levine, supra note 45, at 62; DAELE, supra note 51, \ 5-108.

578 The respective challenge decisions are hereinafter categorized according to the arbitration rules applicable to the dispute, and not according to the decision-making body dealing with the disqualification request. Disqualification decisions taken by the Chairman of the Arbitration Institute of the Stockholm Chamber of Commerce [hereinafter scc Institute] as an Appointing Authority under the uncitral Rules, for example, are summarized in Part 2.2. Since the IBA Guidelines usually only supplement (but don't supersede) the otherwise applicable rules, decisions made in application of the IBA Guidelines are hereinafter classified under the arbitration rules which otherwise apply to the proceeding. Only where parties in ICSID proceedings specifically agreed on the application of the IвA Guidelines, do they supplant the otherwise applicable rules. Such decisions are examined in Part 3 hereinafter.

579 At times, investment disputes are also governed by the LCIA Arbitration Rules. While the LCIA is an important arbitral institution and the public availability of its decisions would have made it interesting to include them in this study, this analysis instead focusses on the arbitration rules most frequently used for the settlement of investor-State disputes, and on the challenge decisions made thereunder.

$580 \quad$ ICC challenge decisions have been unreasoned until recently. The provision of reasons (to the parties, not publicly), was announced by the President of the ICc Court (Alexis Mourre) on September 21, 2015. See Grant Hanessian et al., The ICC Court Decides to Provide Parties With Reasons for Administrative Decisions, Global Arbitration News (Nov. 10, 2015), http://globalarbitrationnews.com/the-icc-court-decides-to-provide-parties-withreasons-for-administrative-decisions-20151110/ [hereinafter Hanessian et al., Reasons for Administrative Decisions]. 
decisions are unavailable, the decisions are sorted by the invoked grounds for disqualification and the requests' outcomes, and listed in bullet point format. The breakdown of the examined cases into these elements allows for a comparison of challenge decisions based on similar constellations across arbitration regimes. The divergences and similarities between the case law under the ICSID Convention and Arbitration Rules and the decisions made under the examined commercial arbitration rules are visualized in a spreadsheet in Part 2.5 of this Chapter.

\subsection{The UNCITRAL Arbitration Rules}

The Arbitration Rules of the United Nations Commission on International Trade Law (UNCIT RAL) were first adopted in 1976,581 and subsequently revised in $2010^{582}$ and $2013 .{ }^{583}$ They represent the second most commonly used framework for the settlement of investment disputes - to date, 234 cases have been brought under the UNCITRAL Arbitration Rules. ${ }^{584}$

Under the UNCITRAL Arbitration Rules, arbitrator challenges are decided by the so-called Appointing Authority. ${ }^{585}$ The Appointing Authority is either

581 Arbitration Rules of the United Nations Commission on International Trade Law, Res. 31/98, U.N. Doc. A/RES/31/98 (Dec. 15, 1976) [hereinafter UnCitral Arbitration Rules $(1976)]$.

582 UNCItral Arbitration Rules as revised in 2010, Res. 65/22, U.N. Doc. A/RES/65/22 (Dec. 6, 2010) [hereinafter UnCitral Arbitration Rules (2010)].

583 UNCITRAL Arbitration Rules (2013), supra note 109. The 2013 revision only added a new paragraph to incorporate the UNCITRAL Rules on Transparency in Treaty-based InvestorState Arbitration. The provisions on arbitrators' independence and impartiality remained unchanged - accordingly, any references to provisions on arbitrator disqualification in the UNCITRAL Arbitration Rules (2013) equally refer to their 2010 version. The rules will hereinafter be referred to as the UNCITRAL Arbitration Rules without reference to a year where any or all versions are meant. It is important to distinguish the UNCITRAL Arbitration Rules from the UnCitraL Model Law on International Commercial Arbitration. The latter is not directed at arbitral parties, but at States. It "reflects worldwide consensus on key aspects of international arbitration practice," and is designed to serve as a basis for States to reform and modernize their domestic laws on arbitral procedure.

584 See List of Cases brought under the UnCITRAL Arbitration Rules, UnCTAD Investment Policy Hub, Investment Dispute Settlement Navigator, http://investmentpolicyhub.unctad .org/ISDS/FilterByRulesAndInstitution. The latest UNCTAD Report reporting the number of investment disputes brought under the UnCitral Arbitration Rules (United Nations Conference on Trade and Development, Report on Recent Developments in Investor-State Dispute Settlement (ISDS), Apr. 2014, http://unctad.org/en/publicationslibrary/webdiaep cb2014d3_en.pdf, at 9 [hereinafter UNCTAD, ISDS Report) puts the number at 158 cases.

585 UnCitral Arbitration Rules (1976) art. 12; UnCitral Arbitration Rules (2013) art. 13, para. 4 . 
designated by the parties in their arbitration agreement, or (in the absence of such designation, or if the specified Appointing Authority fails to act) by the Secretary-General of the PCA, upon the request of the challenging party. ${ }^{586}$

Pursuant to the consistent wording of all versions of the UnCITRAL Arbitration Rules, ${ }^{587}$ arbitrator disqualifications are subject to a justifiable doubts threshold:

Any arbitrator may be challenged if circumstances exist that give rise to justifiable doubts as to the arbitrator's impartiality or independence. ${ }^{58}$

Doubts are justifiable if an objective third party would find them reasonable. ${ }^{589}$

A Behavior in Current Proceeding

Four of the examined UNCITRAL challenges were based on the arbitrators' behavior. All were dismissed.

In National Grid ${ }_{1}{ }^{590}$ Argentina challenged Mr. Judd Kessler, the Claimant-appointed arbitrator. During the cross-examination of an expert witness, Mr. Kessler made a statement which, viewed in isolation, could have been interpreted as a prejudgment of the merits of the case:

It's now clear that there are certain facts that the witness is not familiar with, but I suppose that the basis of his testimony has to do with the hypothetical situation and it's not hypothetical because we are all here. We

586 unCitral Arbitration Rules art. 6. The Secretary-General of the PCA is explicitly mentioned as a possible Appointing Authority in UnCitral Arbitration Rules (2013) art. 6, para. 1.

587 Caron ANd Caplan, supra note 91, at 178 et seqq.

588 UnCitral Arbitration Rules (1976) art. 10, para. 1; UNCITRAL Arbitration Rules (2013) art. 12, para. 1. Interestingly, the threshold for the disclosure of possible conflicts of interest by potential arbitrators is the same (UNCITRAL Arbitration Rules (2013) art. 11), and not higher, as under ICSID Arbitration Rule 6, para. 2 (Chapter 1, Part 1.3).

589 Country X v. Company Q, Challenge Decision (Jan. 11, 1995), in Yearbook Commercial Arbitration 1997 - Volume Xxil 227, 234 (Albert Jan van den Berg ed.). Due to the identical standards of conduct in all versions of the UNCITRAL Arbitration Rules, the case law on arbitrator disqualification under the UNCITRAL Arbitration Rules (1976) remains relevant. See CARON AND CAPLAN, supra note 91, at 178.

590 National Grid plc v. The Republic of Argentina (National Grid II), LCIA Case No. UN 7949, Decision on the Challenge to Mr. Judd L. Kessler (Dec. 3, 2007), available at http://www .iisd.org/pdf/2008/itn_lcia_rulling_kessler_challenge.pdf. In the same case, Dr. Rigo Sureda was also challenged (see infra Part 2.2 B.). 
know the facts generally speaking that there was major harm or major change in the expectations of the investment. ${ }^{591}$

The Appointing Authority ${ }^{592}$ held that under the relevant third person test, the statement had to be viewed as a whole and in the context of the arbitrator's intervention. ${ }^{593}$ As such, it could not reasonably justify such doubts. ${ }^{594}$

In Arbitration 120/2001, ${ }^{595}$ the disqualification of the chairman of the arbitral tribunal was requested based on his interventions in a challenge proceeding against his co-arbitrator. The chairman had tried to persuade the Respondent not to pursue the disqualification request against the Claimant-appointed arbitrator, ${ }^{596}$ and had sought to convince the Appointing Authority not to uphold the challenge. ${ }^{597}$ The chairman characterized his interventions as mere "comments," "reflections," and "friendly invitation[s]."598 The Board of Directors of the Arbitration Institute of the Stockholm Chamber of Commerce ${ }^{599}$ dismissed the challenge for reasons which remain undisclosed. It did make it clear, however, that the request was dismissed on the merits, and not because it was belated or had not been submitted in the correct form, as argued by Claimant. ${ }^{600}$ Hence, the chairman's nudging of the Respondent appears not to have been considered sufficient to raise justifiable doubts about his independence and impartiality.

591 See National Grid II, ๆ $93^{2}$ and 92.

592 The parties had agreed to submit the challenge to a Division of the LCIA Court.

593 National Grid II, ๆ 93.

594 Id. ๆף 96, 99 and 102. See also Fry and Stampalija, supra note 31, at 215 et seqq.; Gabriel Bottini, Should Arbitrators Live on Mars? Challenge of Arbitrators in Investment Arbitration, 32 Suffolk Transnat'L. L. Rev. 341, 354 et seq. (2009).

595 Öhrström, supra note 45, at 49-57 (Arbitration 120/2001).

596 The chairman had even written to the Respondent, stating that "you should certainly have not pursued this challenge."

597 The Respondent further based his request on procedural decisions of the tribunal, i.e. the continuation of the proceeding while the challenge was pending, and a decision on the calculation of fees. These arguments were however not as central as the chairman's nudging of the Respondent.

598 Öhrström, supra note 45 , at 56 (“[T]he notion as such that colleagues on a panel may ... voice their own view on a challenge brought against one of their colleagues is a very wellestablished notion.").

599 Hereinafter the scc Board. The scc Board is the competent body for final decisions on requests for disqualifications under the scc Arbitration Rules (see infra Part 2.3). In this case, it was designated as the Appointing Authority.

6 oo Öhrström, supra note 45 , at 57 . 
Another UnCITRAL challenge was decided by the scc Board in Arbitration 46/2004. ${ }^{601}$ Respondent alleged that the Claimant-appointed arbitrator had ex parte communications with counsel for Claimant, and that this caused an appearance of bias. The existence of ex parte communications, however, could not be proved and was disputed by Claimant, the challenged arbitrators, and the unchallenged arbitrators. Thus, the SCC Board dismissed the challenge.

In Arbitrations U/2003 and 67/2004, Claimant repeatedly challenged the same arbitrator, ${ }^{602}$ based on his claim for additional fees and his refusal to withdraw unless he would be paid such fees. The Chairman of the SCC Institute held that a dispute regarding arbitration costs did not constitute a valid ground for disqualification. ${ }^{603}$

B Familiarity with Another Participant in the Proceeding In five cases, arbitrators were challenged based on their familiarity with another participant in the proceeding. In another case, the tribunal brought up the arbitrator's repeat appointment sua sponte, without a challenge being filed.

In Arbitration 115/2010, Claimant challenged the arbitrator appointed by Respondent based on his academic collaboration with counsel for Respondent. The arbitrator and counsel for Respondent had co-authored several books and articles, and worked at the same university. The scc Board dismissed the challenge. ${ }^{604}$

In Grand River, ${ }^{605}$ the United States challenged Professor James Anaya for being adverse to the United States in cases which were simultaneously pending before the Inter-American Commission on Human Rights and the Committee on the Elimination of Racial Discrimination (CERD). The ICSID SecretaryGeneral held that Respondent's concerns were well-founded because of the "basic similarity" of the issues: All proceedings concerned the compliance of

601 Annette Magnusson \& Hanna Larsson, Recent Practice of the Arbitration Institute of the Stockholm Chamber of Commerce. Prima Facie Decisions on Jurisdiction and Challenges of Arbitrators, 2 Sтоскноцм Авв. Rep. 47, 75-78 (2004) (Arbitration 46/2004).

602 Magnusson and Larsson, supra note 601, at 78-84 (Arbitration U/2003 and 61/2004).

603 Magnusson and Larsson, supra note 6o1, at 80-84.

604 Felipe Mutis Tellez, Arbitrators' Independence and Impartiality: A Review of scc Board Decisions on Challenges to Arbitrators (2010-2012) 5-6 (2012), available at http://www.sccinstitute.com/media/300o1/felipe-mutis-tellez_article -on-scc-challenges-on-arbitrators.pdf.

605 Grand River Enterprises Six Nations Ltd et al v. United States of America (Grand River), Decision on the Challenge to Arbitrator James Anaya (Nov. 28, 2007), available at http:// www.italaw.com/sites/default/files/case-documents/ita0382_o.pdf. 
the United States with "its international commitments." ${ }^{606}$ Professor Anaya was called upon to cease either of his roles, since they were incompatible. After he discontinued his involvement in the human rights cases, ${ }^{607}$ the ICSID Secretary-General dismissed the challenge. ${ }^{608}$ The mere supervision and mentoring of clinical students in the CERD cases was held not to be problematic.

Mr. Stanimir Alexandrov was successfully challenged by Argentina in ICs. ${ }^{609}$ The Appointing Authority in the case, Jernej Sekolec, held that the arbitrator's representation of a Claimant against Argentina in an ongoing (although unrelated) proceeding ${ }^{610}$ put the arbitrator into "a situation of adversity," which is a "source of justified concerns." Mr. Sekolec stated:

[Such situations of adversity] should in principle be avoided, except where circumstances exist that eliminate any justifiable doubts as to the arbitrator's impartiality or independence.

Referring to the Orange List of the IвA Guidelines, Jernej Sekolec affirmed that the situation was serious enough to raise justifiable doubts about the arbitrator's independence and impartiality. ${ }^{611}$ The fact that Vivendi might soon come to an end, and that it was unrelated to ICS, was not enough to resolve such justifiable doubts. ${ }^{612}$

As formulated by Sekolec, the burden of proof relating to a lack of independence and impartiality gets reversed when the challenging party successfully substantiates circumstances that would cause a reasonable third person to justifiably doubt an arbitrator's unbiased decision-making. It is then for the arbitrator to dispel all such doubts. Sekolec argued that even though Vivendi

606 Grand River, at 1.

607 See Letter from S. James Anaya to Nassib G. Ziadé, Deputy Secretary-General International Centre for Settlement of Investment Disputes (Oct. 25, 2007), available at http:// www.naftaclaims.com/disputes/usa/GrandRiver/GRE-USA-Anaya_Challenge-25-10-07. pdf (last accessed on Dec. 30, 2016).

608 Grand River, at 2. See also Sheppard, supra note 32, at 150.

609 ICs Inspection and Control Services Limited (United Kingdom) v. The Republic of Argentina (ICS), PCA Case No. 2010-9, Decision on Challenge to Arbitrator (Dec. 17, 2009), available at http://italaw.com/sites/default/files/case-documents/ita0415.pdf.

610 ICS, at 2. Mr. Alexandrov's law firm (Sidley Austin LLP) also previously represented a company possibly linked to the Claimant. The relevance of this circumstance was however not examined by the Appointing Authority, since Mr. Alexandrov's concurrent representation of an investor in proceedings against Argentina (in Vivendi) was sufficient to give rise to justifiable doubts.

611 Id. at 4.

612 Id. at 4. 
seemed to come to a close, there was still a possibility that Mr. Alexandrov would continue to be involved in the case in some way. Furthermore, even if the cases were unrelated, they were not entirely dissimilar:

Both matters are investment protection actions of considerable magnitude which raise broadly similar concerns against the same State party in a manner that reinforces any justifiable doubts as to the arbitrator's impartiality or independence. ${ }^{613}$

In National Grid, ${ }^{614}$ Argentina brought a challenge against the chairman Dr. Andres Rigo Sureda, based on his role switching with Mr. Tawil (a counsel in the case). Like the challenges brought on the same basis in Azurix and Siemens, the request was dismissed for unknown reasons. ${ }^{615}$ The decision was not published.

The repeat appointment of Professor Albert Jan van den Berg in disputes against Argentina was at the core of his challenge in BG Group. ${ }^{616}$ Instead of alleging a lack of independence, or an imbalance of knowledge on the tribunal, however, Argentina claimed that the arbitrator's inconsistent decisions on the state of necessity in two prior proceedings involving Argentina ${ }^{617}$ were indicative of his lack of independence and impartiality. While the ruling in $L G \& E$ accepted the state of necessity defense for a seventeen month time-frame, the Enron decision denied it. Argentina argued that those findings were contradictory and that a lack of neutrality could be inferred from van den Berg's "arbitrary," "capricious," and "abrupt change of mind." The International Court of Arbitration of the ICC ${ }^{618}$ rejected the challenge, for reasons which remain

613 Id. at 5 .

614 National Grid plc v. The Argentine Republic (National Grid), UnCitral Case.

615 International Institute for Sustainable Development, ICC Nixes Argentina's bid to disqualify Arbitrator in National Grid Case, Investment Treaty News (Jan. 12, 2006), http:// www.iisd.org/pdf/2006/itn_jan12_20o6.pdf. See Sheppard, supra note 32, at 146. The reasons for the challenge are set out in more detail above (Chapter 2, Part 2.2 B., pp. 63-64), in the context of the ICSID disputes in Azurix and Siemens.

616 BG Group plc v. The Republic of Argentina (вG Group).

617 LG\&E Energy Corp., LG\&E Capital Corp., and LG\&E International Inc. v. Argentine Republic $(L G \& E)$, ICSID Case No. ARB/o2/1; Enron Creditors Recovery Corporation (formerly Enron Corporation) and Ponderosa Assets, L.P. v. Argentine Republic (Enron), ICSID Case No. ARB/o1/3. Prof. Albert Jan van den Berg was appointed by the Claimants in BG Group and in $L G \& E$, while the Chairman of the Administrative Council appointed him following the resignation of the Respondent-appointed arbitrator in Enron.

618 Hereinafter the ICc Court. 
unknown. ${ }^{619}$ Argentina subsequently filed a motion to vacate the award rendered in favor of BG Group in the U.s. District Court of the District of Columbia, ${ }^{620}$ on the same grounds. ${ }^{621}$ Its motion was denied. ${ }^{622}$

Finally, the repeat appointment of Dr. Barrera by Ecuador was at issue in EnCana. ${ }^{623}$ No challenge was filed, but the tribunal acknowledged that the situation could cause an inequality of the parties if Dr. Barrera used information attained in the previous proceeding, which his co-arbitrators did not possess. The tribunal stated:

Dr. Barrera cannot reasonably be asked to maintain a "Chinese wall" in his own mind: his understanding of the situation may well be affected by information acquired in the other arbitration. ${ }^{624}$

Nevertheless, the issue was not framed as a hazard to his impartiality, but as a matter of equality of arms. In order to avoid an imbalance of information on the tribunal, Dr. Barrera was asked to disclose any facts he considered relevant for EnCana to the tribunal, and to make the award in the parallel proceeding available to the Claimant as soon as possible after it would be issued. ${ }^{625}$

\section{Familiarity with the Subject-Matter of the Proceeding}

Four of the examined UNCITRAL challenge decisions were based on the arbitrators' familiarity with the subject-matter of the proceeding.

619 Mouawad, supra note 252, at 8-9. Luke Eric Peterson, ANALYSIS: Decrying past "contradictory" rulings, Argentina challenges arbitrator, Investment Treaty News (Apr. 1, 2008), http://www.iisd.org/pdf/2008/itn_april__2008.pdf, 3 [hereinafter Peterson, Argentina].

620 The Republic of Argentina v. BG Group plc, Case No. 08-0485 (R BW) (D.D.C.), Petition to Vacate or Modify Arbitration Award file on March 21, 2008, ๆ ๆ 73, 75 and 76, available at http://ita.law.uvic.ca/documents/BGvArgentina.pdf.

621 Mouawad, supra note 252, at 8; Peterson, Argentina, supra note 619.

622 Ian A. Laird et al., International Investment Law and Arbitration: 2010 in Review, in YEARbook of International Investment LaW and Policy 2010-2011, 130-131 (Karl P. Sauvant ed., 2012).

623 EnCana Corporation v. Republic of Ecuador (EnCana), LCIA Case No. UN3481, Partial Award on Jurisdiction (Feb. 27 2004), I 44 et seqq., available at http://www.italaw.com/ sites/default/files/case-documents/itao283_o.pdf. See also Sheppard, supra note 32, at 154 . Ecuador had mandated the same legal advisors and appointed the same arbitrator in Occidental Petroleum Corporation and Occidental Exploration and Production Company v. Republic of Ecuador (Occidental Petroleum), ICSID Case No. ARB/o6/11.

624 EnCana, 945 .

625 Id. ๆ 46. This approach has been praised as being particularly practical, see Sheppard, supra note 32 , at 154 . How such disclosures could be reconciled with the arbitrator's duty of confidentiality is unclear. 
In CC/Devas, ${ }^{626}$ the chairman of the tribunal, Marc Lalonde, and the Claimant-appointed arbitrator, Professor Francisco Orrego Vicuña, were challenged because they had previously served on tribunals which decided a legal issue that was expected to arise in the case at hand. Professor Orrego Vicuna had chaired three tribunals dealing with "essential security interest" provisions, and defended his position in an article. Mr. Lalonde served as a co-arbitrator on two of these cases. All three decisions were at least partially annulled later on. ${ }^{627}$ Respondent argued that the "strongly held and articulated positions" of the arbitrators in previous proceedings raised doubts about their impartiality. ${ }^{628}$ The President of the International Court of Justice (ICJ), acting as the Appointing Authority in the case, upheld the challenge with respect to Professor Orrego Vicuña. The Professor had dealt with the same legal concept on four previous occasions, and reaffirmed his position after reviewing the respective annulment decisions. The President of the ICJ therefore considered it unlikely that the Respondent could change the arbitrator's mind, and held the Respondent's apprehension of prejudgment to be objectively reasonable. ${ }^{629}$ The disqualification request against Mr. Marc Lalonde, on the other hand, was dismissed. Not only were his statements regarding the "essential security interest" defense more limited, but unlike his co-arbitrator, he did not take a stand on the issue after the annulment decisions were issued. The President of the ICJ therefore relied on the chairman's assurance that he intended to approach the case open-mindedly. ${ }^{630}$

In Telekom Malaysia, ${ }^{631}$ Professor Emmanuel Gaillard was not faced with an issue he had previously decided as an arbitrator, but with a finding made by the arbitral tribunal in $R F C C,{ }^{632}$ which he challenged as counsel in the respective annulment proceeding. Ghana requested his disqualification, arguing that it was impossible for the arbitrator to vehemently oppose an argument as a counsel in one case, and to be unprejudiced with regard to the same issue in another case. Professor Gaillard refused to resign, arguing that no two cases

626 CC/Devas v. Republic of India (CC/Devas), PCA Case No. 2013-09, Decision on the Respondent's Challenge to the Hon. Marc Lalonde as Presiding Arbitrator and Prof. Francisco Orrego Vicuña as Co-Arbitrator (Sept. 30, 2013).

627 Id. \ 3 and 19. The relevant cases are cMs, Sempra and Enron (supra note 334).

$628 I d$. $₫ 17$ and 52.

$629 I d .964$.

$630 \quad I d .966$.

631 Telekom Malaysia Berhad v. Republic of Ghana (Telekom Malaysia).

632 Consortium R.F.C.C. v. Kingdom of Morocco ( $R F C C$ ), ICSID Case No. ARB/oo/6. 
were alike, and that he was able to independently and impartially apply the relevant rules of law to the case. ${ }^{633}$

Ghana's challenge was first adjudicated by the Secretary-General of the PCA (the Appointing Authority), and dismissed without a reasoning. ${ }^{634}$ Ghana subsequently filed a request for disqualification at the seat of the arbitration, with the District Court of the Hague. ${ }^{635}$ Applying Dutch arbitration law, ${ }^{636}$ the District Court conditionally upheld the request, giving Professor Gaillard ten days to resign from his function as a counsel in $R F C C$, lest he be disqualified. ${ }^{637}$ It argued that the mind-set expected of Professor Gaillard in his role as counsel was incompatible with the open-mindedness expected of as arbitrator. Even if he did manage to keep the two roles apart, he could not possibly avoid the appearance of lacking the necessary distance, as long as he concurrently served in both functions. ${ }^{638}$

Professor Gaillard subsequently resigned as a counsel. Ghana filed another challenge with the District Court of the Hague, criticizing the conditional nature of the previous decision, and arguing that Professor Gaillard's resignation as counsel did not eliminate the existing justifiable doubts regarding his independence and impartiality. ${ }^{639}$ The District Court, however, refused to unconditionally disqualify the arbitrator, and explained that:

633 Sheppard, supra note 32, at 151; Mann, supra note 237, at 1; Horvath and Berzero, supra note 37 , at 6 .

634 See Rubins and Lauterburg, supra note 32, at 176.

635 Telekom Malaysia Berhad v. Republic of Ghana (Telekom Malaysia I), Petition No. HA/RK 2004.667, Decision of the District Court of The Hague (Oct. 18, 2004), English translation available at $\mathrm{http} / / / \mathrm{www}$.italaw.com/cases/1091.

${ }_{63} 6$ See Id. If 5. Unlike ICSID arbitration, UNCIT RAL is not a self-contained regime. Hence, the District Court of the Hague was free to apply Dutch arbitration law in the disqualification proceeding. Art. 1033 of the Dutch Code of Civil Procedure however appears to contain a standard similar to that under UNCITRAL. It only surpasses the latter by explicitly requiring appearances to be taken into account: "An arbitrator may be challenged if from an objective point of view ... justified doubts exist with respect to his impartiality or independence. The examination of whether there are sufficient grounds for a challenge should also take account of outward appearance." See Id. ๆ 6 (emphasis added).

637 Id. ๆ 7. See also Brooks W. Daly, Evgeniya Goriatcheva \& Hugh A. Meighen, A Guide to the pCa Arbitration Rules \ 4.59 (2014).

638 Telekom Malaysia I, 96.

639 Telekom Malaysia Berhad v. Republic of Ghana (Telekom Malaysia II), Petition No. HA/RK 2004.788, Decision of the District Court of The Hague (Nov. 5, 2004), English translation available at $\mathrm{http} / / / \mathrm{www} . i t a l a w . c o m /$ cases/1200. 
[I]n international arbitrations, lawyers frequently act as arbitrators. Therefore, it could easily happen in arbitrations that an arbitrator has to decide on a question pertaining to which he has previously, in another case, defended a point of view. Save in exceptional circumstances, there is no reason to assume however that such an arbitrator would decide such a question less open-minded [sic] than if he had not defended such a point of view before. ${ }^{640}$

This decision of the District Court of the Hague seems to be premised on two assumptions: First, Professor Gaillard's concurrent exercise of counsel and arbitrator roles in cases that were unrelated but where the same legal issues were decisive, gave rise to an appearance of bias that would justify his disqualification. Second, this appearance of bias could be remedied by the arbitrator (and hence disqualification avoided), by resigning as a counsel. In other words, a reasonable third person's doubts regarding the arbitrator's cognitive ability to wear a double-hat are justified where an arbitrator simultaneously acts as a counsel in a similar case - if the same happens successively, however, there is no reason to doubt his ability to tell his roles apart. The roles are incompatible when exercised concurrently, but the appearance of independence and impartiality is restored when one of the roles is subsequently discontinued. ${ }^{641}$

In Canfor, ${ }^{642}$ the Claimant-appointed arbitrator Mr. Conrad Harper had given a speech on the subject-matter of the dispute to a Canadian government council prior to the commencement of the arbitration. He had therein expressed his political view on the matter very clearly:

This will be the fourth time we have been challenged. We have won every single challenge on softwood lumber, and yet they continue to challenge us with respect to those issues. Because they know the harassment is just as bad as the process.

The United States argued that this statement amounted to a prejudgment of the dispute and that Mr. Harper was unable to approach the parties' arguments

\footnotetext{
$640 \quad I d$. ๆ1 11.

641 See also Mouawad, supra note 252, at 5 .

642 Canfor Corporation v United States (Canfor), see Canfor Corporation v. United States of America, U.s. DePARtMent of State, http://www.state.gov/s/l/c7424.htm (last accessed on Dec. 30, 2016). The unpublished challenge decision is reported in Legum, supra note 508, at 243. See also Sheppard, supra note 32, at 149.
} 
on the issue with the requisite open-mindedness. The Claimant, on the other hand, pleaded that the arbitrator's statement was innocuous, since it did not concern the investment dispute directly. ${ }^{643}$ The ICSID Secretary-General dealing with the challenge ${ }^{644}$ advised Mr. Harper to resign, or that the challenge would otherwise be upheld. The arbitrator followed this instruction and stepped down. ${ }^{645}$

\section{Connection to an Adverse Third Party}

Four arbitrators were challenged because of connections to an adverse third party.

In Vito Gallo, ${ }^{646}$ an investment arbitration proceeding under NAFTA Chapter $11,{ }^{647}$ Mr. J. Christopher Thomas, Q.C., was challenged because he simultaneously advised Mexico on matters of international trade and investment law. As a party to NAFTA, Mexico was allowed to make submissions in Vito Gallo, although it was not a party to the dispute. ${ }^{648}$ It was argued that Mr. Thomas appeared to be influenced by Mexico's interests - whether or not the country actually intervened.

The Deputy Secretary-General of the ICSID ${ }^{649}$ held that indeed, by simultaneously serving as an arbitrator and as a counsel to a potential third party

643 See Mouawad, supra note 252, at 7; Legum, supra note 508, at 244-245.

644 NAFTA art. 1124, para 1 provides that the ICSID Secretary-General shall serve as Appointing Authority in NAFTA/UnCITRAL cases.

645 Since the arbitrator resigned, ICsID did not publish a decision. Unfortunately, this makes it impossible to analyze the ICSID Secretary-General's motivation of his decision in detail. In particular, it is unclear to which degree the criticized public statements and the subject-matter of the dispute need to overlap. See Legum, supra note 508, at 245 .

646 Vito G. Gallo v. Government of Canada (Vito Gallo), Decision on the Challenge to Mr. J. Christopher Thomas, Q.C. (Oct. 14, 2009), available at http://italaw.com/documents/Gallo-Canada-Thomas_Challenge-Decision.pdf.

647 NAFTA Chapter 11 is the NAFTA investment chapter. It covers the definition of the term investment and the ensuing obligations in its Part A, and investor-State dispute settlement in its Part B. According to NAFTA art. 1120, claims may be submitted under the ICSID Convention, the Additional Facility Rules of the ICSID, or the UnCitral Arbitration Rules. NAFTA disputes brought under the UNCITRAL Arbitration Rules are hereinafter referred to as NAFTA/UNCITRAL cases.

648 NAFTA art. 1128. See Vito Gallo, ๆ 30.

649 NAFTA art. 1124, para. 1 provides that the ICSID Secretary-General shall serve as Appointing Authority in NAFTA/UnCITRAL cases. Whether or not the Deputy Secretary-General was authorized to act in his place by virtue of ICSID Convention art. 10, para. 3 (i.e. in the Secretary-General's absence or due to his inability to act) was disputed in the case. 
participant, "an arbitrator inevitably risks creating justifiable doubts as to his impartiality and independence." ${ }^{650} \mathrm{He}$ highlighted that this was true irrespective of the amount of work performed for, and the remuneration received from the third party. The mere fact that services were provided was enough. ${ }^{651}$ Even if Mexico had not made a submission in the present case, "an apparent conflict of interest [was] perceptible" because of its right to intervene, making it "next to impossible" for Mr. Thomas to avoid the appearance of bias. ${ }^{652}$

The Deputy Secretary-General of the ICSID did not, however, disqualify the arbitrator. Instead, he dismissed the challenge, and gave Mr. Thomas the option of either acting as an arbitrator in the case or advising Mexico. Only if he did not discontinue his advisory services to Mexico for the remainder of the proceedings, justifiable doubts about his impartiality and independence would arise. Mr. Thomas resigned from the arbitration seven days later. ${ }^{653}$

In Eureko, ${ }^{654}$ Poland challenged Judge Stephen M. Schwebel before Belgian courts. It argued that the arbitrator's close working relationship with the Washington D.C. office of Sidley Austin LLP, which was adverse to Poland in an unrelated but ongoing investment arbitration, created an appearance of bias. In the Court of First Instance, Poland referred to reports on the close working relationship in the American Lawyer magazine, to the location of the Judge's office in the same building the law firm, and to his collaboration as a co-counsel with the firm in several investment arbitrations. The court considered those facts insufficient evidence of bias and rejected the challenge. ${ }^{655}$

Poland appealed the decision and invoked additional grounds for the challenge before the Court of Appeals. In particular, it criticized that the Judge based his pleadings as a counsel in an ongoing unrelated arbitration (Vivendi) on the partial award he had co-authored in Eureko. The reliance, in his role as a counsel, on an award he had himself drafted, was argued to indicate a "clear

\footnotetext{
$650 \quad$ Vito Gallo, 931.

$65^{1} \quad I d .932$.

652 Id. ๆ 35 . The Deputy Secretary-General of the ICSID explicitly referenced the IBA Guidelines on Conflicts of Interest in International Arbitration in 936.

653 Giorgetti, Challenges, supra note 32, at 316; Fry and Stampalija, supra note 31, at 221.

654 Eureko B.V. v. Republic of Poland (Eureko), uncitral case; see Sheppard, supra note 32, at 147 and $15^{2}$; Mouawad, supra note $25^{2}$, at $5^{-7}$.

655 In re: The Republic of Poland v. Eureko BV, R.G. 2006/1542/A, Judgement [sic] of the Court of First Instance of Brussels (Dec. 22, 2006), at 5, English translation available at http:// www.italaw.com/documents/Eureko-arbitratorchallenge.pdf.
} 
conflict of interest." ${ }^{256}$ The Court of Appeals dismissed the challenge without considering the new argument, since it had not been raised before the Court of First Instance. With respect to the other bases for the disqualification request, it affirmed the Court of First Instance's ruling.657

In Arbitration 45/2008, Claimant challenged the arbitrator appointed by Respondents. The arbitrator was a long-time academic and legal advisor to Russian government officials, who allegedly had an interest in the outcome of the proceeding. One of the Respondents was an administrative body of a Russian city, and according to Claimant, the Russian government officials had been officials of the city during the relevant period, and had as such been involved in the transactions at issue in the proceedings. Although none of these allegations were disputed by the Respondents or the challenged arbitrator, the SCC Board dismissed the challenge. ${ }^{658}$ The Claimant subsequently substantiated its challenge and submitted evidence for many of the circumstances alleged in its first challenge and certain new grounds. This time, the challenge was upheld. 659

In Suez II, the basis of the challenge was the same as previously described ${ }^{660}$ but the unchallenged arbitrators decided the challenge filed by the third corporate Claimant (AWG Group Limited, hereinafter AWG) separately, since it was subject to the UnCITRAL Arbitration Rules. Adopting a reasonable third person's perspective, they held that the connection between AWG and UBS was too tenuous to give rise to justifiable doubts as to Professor Kaufmann-Kohler's independence and impartiality. ${ }^{661}$

656 Argentina brought forward the same argument in Vivendi, questioning the arbitrator's ability to draft an arbitral award in one proceeding, without (consciously or unconsciously) considering the effect of this award in another dispute, in which he serves as a counsel. It therefore asked for the Eureko award to be disregarded. See Sheppard, supra note 32, at 152; Mouawad, supra note 252, at 6.

657 International Institute for Sustainable Development, Belgian Appeals Court rejects Poland's challenge to Arbitrator in Eureko case, Investment Treaty News (Nov. 15, 2007), http://www.iisd.org/pdf/2007/itn_nov15_2007.pdf.

658 Niklas Lindström, Challenges to Arbitrators - Decisions by the SCc BoArd DURING 2008-2010 10-12, available at http://www.hannessnellman.com/sites/default/ files/media/Challenges_to_Arbitrators__Decisions_by_the_SCC_Board_during _2008_2010.pdf.

659 Lindström, supra note 658 , at 12-14.

66o For details of the circumstances of the case, see supra Chapter 2, Part 2.4, pp. 80-82.

661 Sheppard, supra note 32, at 141. AWG operated in the water sector and uBs conducted research and developed financial products related to the water sector. A closer connection did not exist. In particular, UBS was not a shareholder of AWG. 


\subsection{The scc Arbitration Rules}

The current Arbitration Rules of the scc Institute 662 entered into force on January 1, 2010. They are applicable to arbitration proceedings commenced on or after that date. ${ }^{663}$ The exact number of investment disputes that have so far been brought under the ScC Arbitration Rules is not verifiable ${ }^{664}$ since SCC arbitration is, by default, confidential. ${ }^{665}$ In any event, the scc Institute is a significant player in investment arbitration: It is the second most commonly used institution, after ICSID, and the SCC Arbitration Rules are the third most commonly used instrument for the resolution of investment disputes (after the ICSID Convention and the UnCITRAL Arbitration Rules). Various BITs stipulate that disputes shall be governed by the sCC Arbitration Rules, or that the scc Institute shall act as the Appointing Authority under the UNCITRAL Arbitration Rules. 666

The scc Arbitration Rules explicitly require arbitrators to be independent and impartial. ${ }^{667}$ The threshold applied to arbitrator challenges is that of "justifiable doubts," 668 which is substantively identical to the test applied

662 Arbitration Rules of the Arbitration Institute of the Stockholm Chamber of Commerce [hereinafter the scc Arbitration Rules].

663 Previous versions of the rules dated from 1976, 1988, 1999 and 2007.

664 According to the United Nations Conference on Trade and Development (UNCTAD), 28 investment disputes are known to have been brought under the SCC Arbitration Rules, amounting to about $5 \%$ of arbitrated investment disputes. See UNCTAD, ISDS Report, supra note 584 , at 9 . The Arbitration Institute of the scc, on the other hand, reports that the SCC has administered 85 investment disputes to date, 62 of which were subject to the SCC Arbitration Rules. See Investment Disputes 2015, Arbitration Institute of the Stockholm Chamber of Commerce, http://www.sccinstitute.com/media/181705/ scc-statistics-2015.pdf (last accessed on Dec. 30, 2016).

665 scc Arbitration Rules art. 46.

666 Investment Disputes, Arbitration Institute of the Stockholm Chamber of Сомmerce, http://www.sccinstitute.com/dispute-resolution/investment-disputes/ (last accessed on Dec. 30, 2016).

667 scc Arbitration Rules art. 14, para. 1 ("Every arbitrator must be impartial and independent."). Other than that, the parties are free to appoint arbitrators of any nationality or profession, as there are no pre-established lists from which to choose. See Magnusson and Larsson, supra note 601, at 64 .

668 scc Arbitration Rules art. 15 ("A party may challenge any arbitrator if circumstances exist which give rise to justifiable doubts as to the arbitrator's impartiality or independence."). The 2007 version of the scc Arbitration Rules already contained the same wording in art. 15, para. 1. The 1999 version did not mention the threshold of "justifiable doubts" in the provision on arbitrator challenges (art. 18), but already applied that standard with respect 
under the UNCITRAL Arbitration Rules. ${ }^{669}$ The standard is an objective one, justifiable doubts must thus exist from a reasonable third person's objective point of view. Whether the arbitrator is de facto independent and impartial is irrelevant. ${ }^{670}$

The IBA Guidelines are officially applicable to challenges under the scc Arbitration Rules and are referenced whenever they are pertinent, ${ }^{671}$ although parties rarely refer to them. ${ }^{672}$

Furthermore, Section 8 of the Swedish Arbitration Act (SAA) ${ }^{673}$ contains an illustrative enumeration of circumstances in which an arbitrator should be disqualified because the parties' confidence in their impartiality is deemed to be compromised. ${ }^{674}$ The non-exhaustive catalogue mentions the following scenarios: an arbitrator's potential self-interest (or interest of someone close to them) in the outcome of the proceeding; an arbitrator's position as a director or other representative of an entity or person which has a potential interest in the outcome of the proceeding; and the prior involvement of the arbitrator in the dispute (as an expert, counsel or otherwise).

The final decision on requests for disqualification is made by the SCC Board, whose members are appointed by the Board of Directors of the scc. ${ }^{675}$ In

to arbitrators' disclosure obligations (art. 17), as the current scc Arbitration Rules do (scC Arbitration Rules art. 14, para. 2 and 3).

669 Bernasconi-Osterwalder, Johnson, and Marshall, supra note 32, at 14.

670 Lindström, supra note 658, at 2.

671 Helena Jung, scc Practice: Challenges to Arbitrators. scc Board decisions 2005-2007, Stock. Int'L. Arb. Rev. 1-18, 2 (2008) [hereinafter Jung, scc Practice]; Patrik Schöldström, The Arbitrators, in International Arbitration in Sweden: A PractitioNER's Guide 115, If 7 (Ulf Franke et al. eds., 2013). The Swedish Supreme Court and the Svea Court of Appeal have referred to the IBA Guidelines when deciding challenges and appeals to challenge decisions. See Lindström, supra note 658, at notes 10-11 (arguing, however, that the IBA Guidelines have not been applied strictu senso, but that they provide useful guidance).

672 I IBA Conflict of Interests Subcommittee, The IBA Guidelines on Conflicts of Interest in International Arbitration: The First Five Years 2004-2009, 4 Disp. Resol. J. 5, 33 (2010).

673 The SAA applies to arbitrations seated or otherwise taking place in Sweden, i.e. a majority of the arbitrations administered by the Scc Institute.

674 Öhrström, supra note 45, at 36; Magnusson and Larsson, supra note 601, at 63 .

675 scc Arbitration Rules art. 15, para. 4 and Appendix I to the scc Arbitration Rules art. 3 and 4. Interestingly, the SAA provides for disqualification requests to be adjudicated by the relevant tribunals en banc, including the challenged arbitrator(s). In contrast to the ICSID Convention, the SAA does not provide for an exception from this allocation of competences. Accordingly, a sole arbitrator would have to decide on a requests for his or her 
contrast to challenges under the ICSID Convention, the number of disqualification requests under the SCC Arbitration Rules appears to be unrelated to the overall caseload of the Scc Institute: Despite the increase of the latter, the number of challenges is not on the rise and has been fluctuating very much over the past twenty years. ${ }^{676}$ Generally speaking, the number of disqualification requests is rather low in comparison to the number of arbitrations administered by the scc Institute. 677

Unfortunately, challenge decisions under the SCC Arbitration Rules are unpublished and unreasoned, making it difficult to understand how the relevant rules are interpreted. ${ }^{678}$ Only select ${ }^{679}$ decisions rendered between 1999 and 2012 have been reported by scholars ${ }^{680}$ with more or less details on the backgrounds of the challenges, but without any information on the reasons for the decisions. The most instructive of those decisions will be summarized hereinafter.

A To date, the most frequent (and successful) reason for challenges under the scc Arbitration Rules has been the familiarity of an arbitrator or the arbitrator's law firm with another participant in the proceeding. ${ }^{681}$

In the following constellations, the challenged arbitrator or his / her law firm had an attorney-client relationship with the arbitrator's appointing party

own removal (Schöldström, supra note 671 , 9 33.). This provision of the SAA is however not applicable to arbitrations under the scc Rules.

676 Magnusson and Larsson, supra note 601, at 66; Jung, scc Practice, supra note 671, at 2.

677 Jung, scc Practice, supra note 671, at 1.

678 Bernasconi-Osterwalder, Johnson, and Marshall, supra note 32, at 14; Magnusson and Larsson, supra note 601, at 65; Jung, scc Practice, supra note 671, at 4; Mutis Tellez, supra note 604 , at 4 .

679 Challenge decisions in 32 cases have been reported by the above-mentioned authors: 5 out of 13 cases from 1999 to 2002, 5 out of 19 cases from 2001 to 2004, 6 out of 22 cases from 2005 to 2007,7 out of 14 cases from 2008 to 2010 , and 9 cases from 2010 to 2012.

680 Öhrström, supra note 45; Jung, scc Practice, supra note 671; Helena Jung, The Standard of Independence and Impartiality for Arbitrators in International Arbitration. A Comparative Study Between the Standards of the SCC, the ICC, the LCIA and the AAA (2008), available at http://sccinstitute.com/media/61993/the_standard_of_independence_helena_jung-1.pdf [hereinafter Jung, Comparative Study]; Lindström, supra note 658; Schöldström, supra note 671; Magnusson and Larsson, supra note 6o1; Mutis Tellez, supra note 604.

681 Öhrström, supra note 45, at 35; Jung, scc Practice, supra note 671 , at 1 . Challenges were based on such grounds in 20 reported cases. 
or an entity related to it. This was held to create an appearance of bias in favor of the appointing party, and the arbitrator was disqualified:

- The arbitrator's partners had given legal advice in unrelated matters to his appointing party "from time to time." 682

- The arbitrator's co-worker represented the appointing party's parent company in a different, unrelated dispute. ${ }^{683}$

- The chairman's law firm had received three unrelated assignments from one of the parties in the same year. ${ }^{684}$

- The arbitrator's law firm had previously dealt with his appointing party on five unrelated occasions. In one of these instances, at a time when events relevant in the arbitration occurred, the arbitrator personally advised the appointing party's majority shareholder on the acquisition of a majority of the shares in the appointing party, together with the firm who represented the appointing party in the arbitration. ${ }^{685}$

- The arbitrator's law firm had previously advised the appointing party and its major shareholder, although it was argued that those contacts were of a limited scope and commercially insignificant. ${ }^{686}$

- The arbitrator's law firm had represented his appointing party in a closelyconnected dispute until six months earlier. ${ }^{687}$

- The arbitrator had previously represented his appointing party (Claimant) in a proceeding before a national court and acted as counsel in an unrelated ongoing proceeding, in which the counter-party was represented by counsel for Respondent. ${ }^{688}$

- The arbitrator had provided services to his appointing party on a day-to-day basis during the past four years, and who was a long-time friend and professional colleague of the company's managing director. ${ }^{689}$

Where the arbitrator had ceased to work for the law firm representing his appointing party, no appearance of bias was found:

682 Öhrström, supra note 45, at 41-42 (Arbitration 6o/1999). The challenging party argued that the arbitrator was conflicted, since the firm's partners shared a common interest.

683 Öhrström, supra note 45, at 49 (Arbitration 6o/2001).

684 Jung, scc Practice, supra note 671, at 6 (Arbitration 53/2005).

685 Lindström, supra note 658, at 16-19 (Arbitration 68/2010).

686 Mutis Tellez, supra note 604, at 11 (Arbitration 170/2011).

687 Id. at 11-12 (Arbitration 174/2011).

688 Id. at 12-13 (Arbitration 177/2011).

689 Id. at 14-15 (Arbitration 78/2012). 
- The arbitrator had worked in the law firm representing his appointing party for twelve years, up to seven years before the commencement of the arbitration. ${ }^{690}$

- The arbitrator had been a partner in the firm representing his appointing party for four years. At that time, however, the counsel involved in the arbitration was not yet working for the firm, and the arbitrator never met him. ${ }^{691}$

In the following situations, prior contacts were held to create an appearance of bias against one of the parties, and the arbitrator was disqualified:

- The arbitrator's law firm was currently and had in the past been involved in cases for and against the challenging party and one of its subsidiaries. ${ }^{692}$

- The arbitrator had issued a legal opinion in an ongoing arbitration between the challenging party and one of its group companies, on behalf of the latter. ${ }^{693}$

- In two unrelated litigation proceedings, in which the arbitrator was sued, counsel for Claimant represented the Claimants. ${ }^{694}$

Animosity between an arbitrator and a counsel in the arbitration based on their confrontation in another proceeding was held not to be a sufficient ground for disqualification in the following constellations:

- The chairman was concurrently involved in a court case, representing the defendant, while one of the counsel in the arbitration represented the plaintiff. In the court case, the chairman raised allegations of unethical behavior against the counsel. ${ }^{695}$

- The arbitrator had previously served as a counsel in a proceeding where the chairman's spouse represented the counterparty, and had strongly criticized her, causing strong conflict and antagonism. ${ }^{696}$

\footnotetext{
690 Jung, scc Practice, supra note 671, at 9-11 (Arbitration 2/2006).

691 Id. supra note 671, at 9-11 (Arbitration 2/2006).

692 Mutis Tellez, supra note 604, at 9-10 (Arbitration 124/2011).

693 Jung, scc Practice, supra note 671, at 14 (Arbitration 46/2007). The line of arguments of the party contesting the challenge was very similar to that of decision-makers in ICSID challenge proceedings: It claimed that the challenge was not based on "actual or specific circumstances" but on an insufficient, "abstract or theoretical bias based on principles".
}

694 Lindström, supra note 658, at 19-20 (Arbitration 58/2008).

695 Magnusson and Larsson, supra note 601, at 74-75 (Arbitration 14/2004).

696 Lindström, supra note 658, at 9-10 (Arbitration 1/2010). 
Furthermore, prior contacts were held not to cause justifiable doubts as to the arbitrators' independence and impartiality in the following cases, and the challenges were dismissed:

- The arbitrator's cousin was a board member of the appointing party's parent company. ${ }^{697}$

- A former lawyer in the firm that was representing the arbitrator's appointing party had represented the arbitrator in a dispute relating to arbitrator's fees, but left the firm in the meantime. ${ }^{698}$

- The arbitrator's company had repeatedly performed services for his appointing party. 699

- The chairman had worked with a decisive witness before: he had served as an arbitrator in four disputes in which the witness was called as an expert. ${ }^{700}$

- The arbitrator had previously advised the firm of the witness called by his appointing party on internal matters. ${ }^{701}$

Arbitrators were challenged based on repeat appointments in three reported cases. An arbitrator who was appointed by the same law firm in eight cases within two years, and by the same corporate group in six cases was disqualified. His appointments by the law firm made up for a significant part of his caseload. ${ }^{702}$ In another case, the arbitrator was appointed by the same party "on several prior occasions," and was the chairman (as well as a member of the

697 Öhrström, supra note 45 , at $47-48$ (Arbitration $87 / 2000$ ). The sCC Board's dismissal is surprising, since SAA Section 8 requires the disqualification of an arbitrator if a person "closely associated" to them is a director or otherwise represents an entity which might derive a benefit or a detriment from the outcome of the proceeding. It appears that cousins are not considered to be such "closely associated" persons.

698 Magnusson and Larsson, supra note 601, at 66-68 (Arbitration 72/2003).

699 Jung, scc Practice, supra note 671, at 12 (Arbitration 19/2006).

700 Lindström, supra note 658, at 7-9 (Arbitration 137/2008).

701 Id. at $7-9$ (Arbitration $137 / 2008$ ).

702 Magnusson and Larsson, supra note 601, at 71 (Arbitration 14/2004). Out of 21 appointments between 2002 and 2004, 7 cases were still ongoing at the time of the proceeding, and in 5 of the arbitrations, the arbitrator was appointed by the same law firm. The challenging party stressed the relevance of appearances, stating that: "The ability or intention to decide the matter in an impartial manner ... is of no relevance if ... justifiable doubts as to the arbitrator's impartiality and independence are present." It did not seem to matter that a different lawyer had made each individual appointment because of the arbitrator's legal specialization, and that the arbitrator was unaware of the corporate affiliation of his appointing parties. 
ethical board) of an industrial association which two companies controlled by the appointing party belonged to. He was also disqualified..$^{703} \mathrm{In}$ an investment arbitration between a British investor and Russia, the challenge of the Claimant-appointed arbitrator, who had served in unrelated arbitrations against Russia on two prior occasions, was dismissed. ${ }^{704}$

\section{B Familiarity with the Subject-Matter of the Proceeding}

Challenges based on the familiarity of an arbitrator with the subject-matter of the proceeding appear to be rarer, or are at least not reported as extensively. They were upheld in three cases in which the arbitrator's law firm dealt with one of the parties as well as the subject-matter of the proceeding. In the first case, the law firm which the chairman previously worked for had drafted the contract in dispute while he was working there. ${ }^{705}$ In the second case, the arbitrator's law firm had advised the appointing party on similar issues, possibly even on how to handle the current dispute. ${ }^{706}$ In the third case, the arbitrator owned a company which had competed with the appointing party for the contract in dispute, but was turned down by the challenging party. After the alleged breach of the contract in dispute, the arbitrator and his company were contacted by the challenging party to obtain a proposal for the remediation of the alleged defects. Their offer was again rejected. Not only the prior involvement but also the knowledge of commercial and technical details at issue were claimed to undermine the arbitrator's independence and impartiality. ${ }^{707}$

Another challenge based on the arbitrator's familiarity with the subjectmatter in dispute was dismissed: The arbitrator had previously adjudicated cases which were allegedly related to the arbitration at issue, and the knowledge acquired in those matters was argued to put the challenging party at a disadvantage. ${ }^{708}$ The scarce information available, however, neither elucidates

703 Lindström, supra note 658, at 14-16 (Arbitration 18/2009).

704 Öhrström, supra note 45 , at 42-46 (Arbitration 10/2000). Russia further argued that the first arbitration, which had led to a substantial award in damages, was decisive for the current proceeding, in which Russia's financial condition was at issue.

705 Jung, Comparative Study, supra note 680, at 19. Furthermore, the chairman and counsel for Respondent previously worked at the same law firm and were involved in an unrelated arbitration in the same roles.

706 Mutis Tellez, supra note 604, at 13-14 (Arbitration 81/2012). It did not matter that advice rendered to the appointing party did not generate considerable income, and that the arbitrator was not personally involved.

707 Id. at 6-8 (Arbitration 19o/2010).

708 Magnusson and Larsson, supra note 601, at 68-70 (Arbitration 148/2003). 
whether the proceedings were indeed related to similar issues, nor does it explain why the challenge was dismissed.

\subsection{The Icc Arbitration Rules}

The current Arbitration Rules of the International Chamber of Commerce (ICC $)^{709}$ came into force on January 1, 2012, and apply to all ICC arbitrations which commenced on or after that date. Their precursor dated from January 1 , $1998 .{ }^{710}$ Currently, only six investment arbitration disputes are known to have been brought under the ICC Arbitration Rules. ${ }^{711}$ ICC arbitrations are, however, by default confidential ${ }^{712}$ - it is therefore possible that a larger number of investment disputes have been resolved under the auspices of the ICC.

Under the ICC Arbitration Rules, the ICC Court is competent to ensure arbitrators' independence and impartiality. ${ }^{713}$ Despite its name, it is not an actual judicial body, but the organ that administers ICC arbitrations. It is, among other things, responsible for the confirmation of party-appointed arbitrators, and the scrutiny and approval of awards rendered under the ICC Arbitration Rules. ${ }^{714}$ The members of the ICC Court are elected by the ICC World Council, with the involvement of the National Committees or Groups, as well as the ICC Executive Board. ${ }^{715}$ Accordingly, they inevitably have strong ties to the members of such National Committees or Groups - i.e. to their domestic arbitration communities. They are however required to be independent from them in their function as members of the ICC Court. ${ }^{716}$ Furthermore, when they serve as ICC arbitrators, they but must be absent from all related discussions and decisions of the ICC Court. ${ }^{717}$

The ICC Arbitration Rules provide for arbitrators' independence and impartiality to be examined in two steps: First, at the appointment stage, and second,

709 Rules of Arbitration of the International Chamber of Commerce [hereinafter ICc Arbitration Rules].

710 Hereinafter ICC Arbitration Rules (1998). The provisions on arbitrators' independence and impartiality of the ICC Arbitration Rules (1998) might still be relevant in ongoing proceedings which were commenced prior to January 1, 2012, or where the parties have agreed on their application.

711 See UNCTAD, ISDS Report, supra note 584, at 9. See also List of Cases brought under the uncitral Arbitration Rules, unctad Investment Policy Hub, Investment Dispute Settlement Navigator, http://investmentpolicyhub.unctad.org/ISDS/FilterByRules AndInstitution.

712 See ICC Arbitration Rules art. 22, para. 3.

713 ICC Arbitration Rules art. 14, para. 3.

714 ICC Arbitration Rules art. 1, para. 2 and art. 13, para. 1 and 2.

715 Appendix I to the ICC Arbitration Rules art. 3.

716 Appendix II to the ICC Arbitration Rules art. 3, para. 1.

717 Appendix II to the ICC Arbitration Rules art. 2, para. 4. 
if a party challenges an arbitrator. Unlike arbitrators in disputes subject to the ICSID Convention or the SCC Arbitration Rules, arbitrators in ICC arbitrations require the institution's confirmation of the parties' nomination. In this confirmation process, the ICC Court or the Secretary General ${ }^{718}$ make a first assessment of the nominees' neutrality. In doing so, they take the parties' objections to the nomination into consideration. ${ }^{719}$ Arbitrators who are confirmed by the institution can still be challenged by the parties. Such disqualification requests are dealt with by the ICC Court. In practice, the ICC Court appoints one of its members to prepare a report on the challenge, and then decides en banc. ${ }^{720}$

The independence and impartiality of arbitrators is governed by Article 11 para. 1 ICC Arbitration Rules:

Every arbitrator must be and remain impartial and independent of the parties involved in the arbitration..$^{721}$

718 The Secretary General is competent to confirm arbitrators who have submitted unqualified statements of acceptance (i.e. who attested that they had no potential conflicts of interest to disclose) and arbitrators to whose nomination the parties did not object (in the absence of or despite disclosures of potential conflicts of interest). The ICC Court decides on the confirmation of arbitrators to whose nomination a party has objected or whom the Secretary General decides not to confirm. See ICC Arbitration Rules art. 13, para. 1 and 2.

719 Jung, Comparative Study, supra note 680, at 21. Where parties fail to appoint an arbitrator, the ICC Court proceeds with the appointment (ICC Arbitration Rules art. 12, para. 4), usually upon the proposal of an ICC National Committee (ICC Arbitration Rules art. 13, para. 3 and 4). In this case, the Court will normally ensure the arbitrator's absolute independence and therefore not accept a qualified Statement of Independence. Accordingly, the parties are not given the opportunity to submit objections prior to the arbitrator's appointment. However, they may still challenge the arbitrator once she or he has been appointed. See Anne Marie Whitesell, Independence in Icc Arbitration: ICc Court Practice concerning the Appointment, Confirmation, Challenge and Replacement of Arbitrators, in icc International Court of Arbitration Bulletin, 2007 SpeCial Supplement, Independence of Arbitrators 7, 12 (2008).

720 Michael W. Bühler \& Thomas H. Webster, Handbook of icc Arbitration 9 11-31 (1st ed. 2005).

721 ICC Arbitration Rules (1998) art. 7, para. 1 contained the same wording, but without any reference to impartiality. Apparently, the lack of a satisfactory definition of impartiality was one of the reasons for omitting the requirement. See Sheppard, supra note 32 , at 134 \& n.19; Schwartz AND Derains, supra note 87 , at 117. Arbitrators could, however, be challenged "for an alleged lack of independence or otherwise" (ICC Arbitration Rules (1998) art. 11, para. 1), and the requirement of impartiality was de facto subsumed under "otherwise" (see Bernasconi-Osterwalder, Johnson, and Marshall, supra note 32, at 15; Blackaby et al., supra note 90, 9 4.78; Jacob Grierson \& Annet van Hooft, Arbitrating under the 2012 icc Rules 18 (2012); Andreas Reiner \& Christian Aschauer, Commentary Article 11, in Institutional Arbitration, 205 (Rolf A. Schütze 
According to the ICC Court's practice, the requirement of independence and impartiality is mandatory. It is even upheld where the parties have agreed on the appointment of non-independent arbitrators. ${ }^{722}$

The threshold for a successful disqualification request is not specified in the ICC Arbitration Rules. It cannot be derived from Article 11 para. 2 ICC Arbitration Rules, which establishes a reasonable doubts standard for disclosure obligations only. ${ }^{723}$ Scholars have stressed that in contrast to the subjective perspective from which disclosure obligations are to be examined, the vantage point for the evaluation of disqualification requests is an objective one..$^{724}$ This does not, however, determine the threshold for a disqualification: Does the challenging party have to prove that the arbitrator is biased, or merely that she or he appears biased? Are justifiable doubts regarding the arbitrator's independence and impartiality sufficient for a challenge to succeed or does the challenging party carry the full burden of proof for the decision-maker's actual lack of independence and impartiality? According to Whitesell, there is no unequivocal answer to those questions:

The Court does not apply a single standard to all cases, but rather decides the questions in each case on their own merits. ${ }^{725}$

ed., 2013) [hereinafter Reiner and Aschauer, Art. 11]). Under the current ICC Arbitration Rules, a challenge is possible based on "an alleged lack of impartiality or independence, or otherwise" (ICC Arbitration Rules art. 14, para. 1).

722 Whitesell, supra note 719, at 14; SCHWARTZ AND DERAINs, supra note 87, at 142.

723 See also ICC Arbitrator Statement of Acceptance, Availability And Independence (2012 ICC Arbitration Rules), available at http://www.iccwbo.org/Products-and-Services/Arbitration-and-ADR/Arbitration/Practice-notes,-forms,-checklists/ (last accessed on Dec. 30, 2016) (putting the general requirement of disclosing "any facts or circumstances which might ... call into question the arbitrator's independence ... [or] give rise to reasonable doubts as to the arbitrator's impartiality" into more concrete terms by requiring the disclosure of "any past or present relationship, direct or indirect, whether financial, professional or ofany other kind, between you and any of the parties, their lawyers or other representatives, or related entities and individuals" and by expressly stating that "[a]ny doubt must be resolved in favor of disclosure").

724 Bernasconi-Osterwalder, Johnson, and Marshall, supra note 32, at 15; Whitesell, supra note 719, at 11; Schwartz And Derains, supra note 87, at 122. But see Jason Fry \& Simon Greenberg, The new Icc Rules on Arbitration: How Have They Fared After the First 18 Months?, 16 InT'L. ARB. L. REv. 171, 176 (2013) (applying a subjective test to disclosures relating to independence only, and an objective test to disclosures regarding impartiality).

725 Whitesell, supra note 719, at 7. Contra Schwartz And Derains, supra note 87, at 121122 (arguing that at the confirmation stage, a "reasonable doubts" standard is applied, while at the challenge stage, an arbitrator must appear likely not to be independent to be disqualified). 
The consideration of the idiosyncrasies of every specific case is undoubtedly an important element of individual fairness, and attention to such specificities is particularly important in a dispute settlement system as strongly built on party autonomy as arbitration. Nevertheless, if there truly is no abstract standard - a metric to measure the specific circumstances of a case by - this might seriously impede the predictability and the uniformity of the ICC case law on arbitrator challenges. ${ }^{726}$

The IBA Guidelines are not binding on the ICC Court, which has repeatedly highlighted the "fundamental incompatibility" between the ICC Arbitration Rules and the IBA Guidelines. Since the ICC Arbitration Rules provide for a subjective test of which circumstances should be disclosed, there is no room left for the IвA Guidelines' Green List, according to which certain situations never require disclosure. ${ }^{727}$ Nevertheless, the IвA Guidelines are usually mentioned by the ICC Secretariat, in its briefing of the ICC Court on challenges. They appear to be a persuasive authority for the interpretation of the disqualification standard under the ICC Arbitration Rules, ${ }^{728}$ and might enhance the predictability and uniformity of challenge decisions. ${ }^{729}$ They further assist prospective arbitrators in deciding whether to disclose potential obstacles to their independence or impartiality. ${ }^{730}$

Other than the IBA Guidelines, specific standards for arbitrator challenges in the law and practice at the place of the arbitration and at the probable place of enforcement are determinative. ${ }^{731}$

In contrast to the ICSID system, the number of challenges in ICC proceedings has not significantly increased over time. ${ }^{732}$ Whitesell argues that this circumstance bears witness to the effectiveness of the ICC Court's review of

726 See also MontT, supra note 26 , at 150 (criticizing, in the context of investment arbitration, the common emphasis on a case-by-case aproach: "It is a truism that all cases need must [sic] be decided individually, on their own terms, and in light of all relevant circumstances. So, when tribunals state and highlight these propositions ... it may mean something else. Many times, what is really being said is that the tribunal will reach its decision according to its own sense of justice and fairness.").

727 Jung, Comparative Study, supra note 680, at 20. Whitesell, supra note 719, at 36.

728 DAE LE, supra note 51, 9 5-046; I IBA Conflict of Interests Subcommittee, supra note 672, at 28-29. Contra Whitesell, supra note 719, at 36.

729 Contra Whitesell, supra note 719, at 37 (arguing that the IBA Guidelines fail to cover many of the alleged conflicts of interest arising in the ICC practice).

730 GRIERSON AND VAN HoOfT, supra note 721, at 132.

731 Bühler AND Webster, supra note 720, ๆ 9 11-17 (1st ed. 2005).

$73^{2}$ Andreas Reiner \& Christian Aschauer, Commentary Article 14, in Institutional ARbiTRATION, 314 (Rolf A. Schütze ed., 2013). 
independence and impartiality during the confirmation process. ${ }^{733}$ Indeed, objections to an arbitrator's confirmation seem to carry a lot of weight: In the past, at least, they led to a denial of the confirmation in a majority of cases. ${ }^{734}$

This Part will summarize some of the known disqualification decisions, in an attempt to derive a common challenge standard from the case law. Since the ICC Court's disqualification decisions were neither published nor reasoned ${ }^{735}$ until recently, ${ }^{736}$ it is difficult to establish a representative interpretation of the ICC Arbitration Rules' challenge standard based on the outcome of individual reported disqualification proceedings. ${ }^{737}$ This study will nevertheless attempt to provide some useful insight.

\section{A Familiarity with Another Participant in the Proceeding}

As in other arbitration mechanisms, previous contacts between an arbitrator or his firm on one side, and a party or their counsel on the other side, are frequent grounds for objections to arbitrators' confirmations and for disqualification requests under the ICC Arbitration Rules. Throughout this category, however, the degree of proximity between the challenged arbitrator and the respective party varies widely, and with it the likelihood of the objection's or the challenge's success.

733 Whitesell, supra note 719 , at $26-27$.

734 Schwartz and Derains, supra note 87, at 136.

735 See ICC Arbitration Rules (1998) art. 7, para. 4 and ICC Arbitration Rules art. 6. The ICC has justified the absence of a reasoning of the Court's challenge decisions with the specific circumstances under which decisions are made: Disqualification requests are considered at plenary sessions, by 35 to 45 members from various countries, who almost always reach a consensus, but may have different reasons for the same conclusion. It was argued that it would be impractical to require them to agree on a uniform substantiation of the decision, and that unreasoned challenge decisions are a necessary trade-off for the geographically and culturally broad basis of challenge decisions which lends the ICC Court its democratic legitimacy. See Whitesell, supra note 719, at 39. But see ScHWARTZ AND DERAIns, supra note 87, at 139 (arguing that the decisions are mainly unreasoned "to avoid causing possible embarrassment or offense to the arbitrators concerned."). It is indeed questionable why such important decisions are made by such a large and unaccountable body, which is rumored to be susceptible to improper "lobbying" when deciding on challenges. See Rogers, Eтhics, supra note 98, ๆ 2.70.

736 On 21 September 2015, the President of the Icc Court (Alexis Mourre) communicated that the ICC Court will forthwith provide information on administrative decisions taken by the institution to the parties (but not publish the decisions). This includes challenge decisions pursuant to ICC Arbitration Rules art. 14. See Grant Hanessian et al., Reasons for Administrative Decisions, supra note 580 .

737 See BüHLER ANd Webster, supra note 720, \ 11-32; Bernasconi-Osterwalder, Johnson, and Marshall, supra note 32 , at 16. 
In the following instances, the challenged arbitrator or another attorney in their law firm had an attorney-client relationship with the arbitrator's appointing party or an entity related to it. The confirmation was denied or the arbitrator disqualified:

- The arbitrator was "of counsel" of the law firm representing his appointing party. ${ }^{738}$

- The arbitrator worked as a consultant and counsel for the law firm representing his appointing party. ${ }^{739}$

- The arbitrator previously served as a counsel to his appointing party in unrelated matters. ${ }^{740}$

- The arbitrator's law firm represented one of the parties in court proceedings which were terminated at the time of the challenge. ${ }^{741}$

- A foreign office of the arbitrator's law firm advised his appointing party on an unrelated transaction. ${ }^{742}$

In two cases in which no objection against the arbitrator's confirmation was raised, ${ }^{743}$ the attorney-client relationship between an arbitrator's law firm and a party did not lead to a disqualification:

- Several offices of the arbitrator's law firm had ongoing attorney-client relationships (regarding unrelated matters) with one of the parties. ${ }^{74}$

- The chairman's law firm was concurrently advising one of the Respondents on a litigation proceeding involving a subsidiary of one of the Claimants. ${ }^{745}$

738 Whitesell, supra note 719, at 21 (case 4). The arbitrator had failed to disclose this fact, but his phone number and address were identical to those of counsel for his appointing party.

739 Id. at 29 (case 8). For the summary of a case in which the chairman was of counsel at a law firm which advised several companies which were affiliated with one of the arbitration parties, and the ensuing annulment of the partial award rendered by the chairman, see Reiner and Aschauer, Art. 11, supra note 721, at 211.

740 Whitesell, supra note 719, at 23 (case 3).

741 Reiner and Aschauer, Art. 11, supra note 721, at 210.

742 Whitesell, supra note 719, at 21 (case 4), 23 (case 3), and 29 (case 8).

743 The lack of objections to the arbitrators' appointments comes as a surprise in these cases. Usually, disclosures which raise important questions with regard to arbitrators' independence and impartiality lead to follow-up questions, at least. See Whitesell, supra note 719 , at 17 .

744 Jung, Comparative Study, supra note 680, at 23 (case 1). The arbitrator was not personally involved and the work did not involve significant amounts of money.

745 Whitesell, supra note 719, at 17 (case 3). Furthermore, the chairman had recently acted as an arbitrator in a proceeding involving one of the Claimants. It is unclear who had appointed him. 
Arbitrators were further disqualified based on contacts with a party or their counsel in the following cases:

- The arbitrator was a director of a company which was represented by the counsel of his appointing party in an unrelated proceeding. ${ }^{746}$

- The arbitrator's spouse was a partner in the law firm that had nominated him. ${ }^{747}$

- The arbitrator was a former employee of a direct and an indirect subsidiary of a party. He had worked in the companies' legal departments for a total of ten years, and his employment had only ended one year prior to his nomination. ${ }^{748}$

- The arbitrator was a partner at a law firm which was in an alliance with the law firm representing one of the parties. ${ }^{749}$

- The arbitrator was the acting director of the biggest shareholder of another company, which was in turn the Respondent's largest shareholder. ${ }^{750}$

Whether an appearance of bias against an arbitration party can arise from the representation of its counterparty in another proceeding appears not to be settled. In one reported case, a chairman was disqualified because a foreign office of his law firm was involved in an unrelated lawsuit against a parent company of one of the parties. ${ }^{751}$ In another case, an arbitrator's law firm had represented a third party in an unrelated proceeding against a subsidiary of an arbitration party five years earlier. In this case, the challenge was dismissed. ${ }^{752}$ The different outcomes of the disqualification requests are surprising, since the circumstances of the cases were very similar. Without a more detailed knowledge of the cases, it is impossible to explain the different outcomes of the challenges

746 Reiner and Aschauer, Art. 11, supra note 721, at 210.

747 Id. at 210.

748 Jung, Comparative Study, supra note 680, at 25 (case 2).

749 Reiner and Aschauer, Art. 11, supra note 721, at 210. The law firms were legally and financially independent. Their alliance meant that they shared office space in some of their locations and organized common seminars and workshops.

$75^{\circ}$ Whitesell, supra note 719, at 21 (case 1).

$75^{1}$ Jung, Comparative Study, supra note 680, at 26 (case 5). According to Reiner and Aschauer, the geographic dispersal of large law firms should not serve as a mitigating factor in the assessment of potential conflicts of interest, since all offices of such firms are usually subject to a uniform strategy and under the same management (Reiner and Aschauer, Art. 11, supra note 721 , at 213).

$75^{2}$ Jung, Comparative Study, supra note 68o, at 24-25 (case 6). 
and to derive a reliable rule on how to assess such cases. One could surmise that it made a difference in the assessment of the cases how long ago the previous proceeding took place, or what the roles of the specific arbitrators were.

Whether the familiarity of an arbitrator with a counsel through membership in the same British Chambers leads to disqualification seems to depend on the geographical setting. In one ICC challenge, the arbitrator was a member in the same British Chambers (Blackstone Chambers) as counsel for her appointing party. ${ }^{753}$ The place of arbitration was Vienna, where the British concept of barristers, solicitors and Chambers is foreign. This gave rise to a more critical and cautious evaluation of the arbitrator's impartiality and independence. ${ }^{754}$ As a consequence, the ICC Court held that although barristers are formally self-employed and Chambers do not have a collective legal identity, in practice, they are conceived as a "club." In another case, in which the arbitrator also belonged to the same British Chambers as counsel, but London was the place of arbitration, and counsel for both parties (but not the parties themselves) were from London, the challenge was dismissed. ${ }^{755}$

To date, all reported challenges of public servants appointed as arbitrators have been dismissed. In one such case, the arbitrator was a former employee of the Ministry of Foreign Affairs of her appointing State, whose employment had terminated ten years earlier. At the time, she had held the same position as the person now representing the State. ${ }^{756}$ In another case, the arbitrator was a former minister of his appointing State, whose employment by the State in various positions dated more than twenty years back. ${ }^{757}$ Finally, the challenge of an arbitrator whose employment with the government only dated back almost four years was dismissed. He had previously worked for the State's Ministry of Justice and as its Solicitor General (none of which were responsible for the project in dispute). In this role, he had acted as a defense counsel for the government in several ICC arbitrations. ${ }^{758}$

753 ICC Case No. 16553/GZ, summarized in Horvath and Berzero, supra note 37, at 10.

754 Horvath and Berzero, supra note 37, at 11. The geographic setting also matters in ICSID challenges to counsel, based on such circumstances. See Hrvatska Elektroprivreda d.d. v. Republic of Slovenia (Hrvatska), ICSID Case No. ARB/05/24, Decision on the Participation of a Counsel (May 06, 2008), ๆ 10 ("[W] hat may not, apparently, be cause for concern in London may well be viewed very differently by a reasonable third person from Africa, Argentina, or Zagreb, Croatia.").

755 ICC Case No. 1586o/VRO/MLK, S.P. 26.03.2009, summarized in Horvath and Berzero, supra note 37 , at 11 .

$75^{6}$ Whitesell, supra note 719, at 19 (case 6).

757 Id. at 18 (case 14).

$75^{8}$ Id. at 16 (case 5 ). 
The following forms of previous contacts between an arbitrator or their law firm and a counsel were considered less problematic and objections to the arbitrators' confirmation or challenges were dismissed:

- The arbitrator and counsel for his appointing party acted as co-counsel in two unrelated cases, and co-edited a book on arbitration. The arbitrator further issued legal opinions for a party represented by the counsel in an unrelated non-ICC case. ${ }^{759}$

- The arbitrator had previously issued legal opinions in four matters for parties represented by counsel for his appointing party. ${ }^{760}$

- The arbitrator had issued a legal opinion in an unrelated matter for his appointing party seven years earlier. ${ }^{761}$

- A partner in the chairman's law firm previously represented a party in an unrelated non-ICC arbitration, in which one of the current counsel acted as the chairman. ${ }^{762}$

- The chairman and a co-arbitrator concurrently served in another, unrelated dispute, in reversed roles. ${ }^{763}$

- The arbitrator and counsel for his appointing party were classmates in law school. 764

- The arbitrator had supervised the doctoral thesis of counsel for his appointing party. ${ }^{765}$

- Five years earlier, the arbitrator gave legal advice to a firm in which one of the counsel worked at the time. ${ }^{766}$

Challenges based on repeat appointments are relatively rare in ICC arbitration, or at least not widely reported. The frequency of repetitive nominations by the same party or through the same law firm, as well as the parties involved in such proceedings, will determine whether an arbitrator is confirmed or

759 Id. at 23 (case 2). The arbitrator had also issued legal opinions for parties represented by counsel for the other party in an unrelated case. This circumstance might have made a difference for the Court's decision.

$760 \quad I d$. at 18 (case 10).

761 Jung, Comparative Study, supra note 68o, at 24 (case 4).

762 Id. at 24 (case 5).

763 Whitesell, supra note 719 , at 32 (case 11 ).

$764 I d$. at 19 (case 4).

$765 I d$. at 31 (case 4).

766 Jung, Comparative Study, supra note 680, at 23 (case 3). 
disqualified. ${ }^{767}$ In the following constellations, arbitrators were not confirmed or they were disqualified:

- The arbitrator concurrently served as an arbitrator in a parallel proceeding, which was not directly linked to the arbitration at issue and did not involve the arbitrator's nominating party (Claimant). The appointing party in the parallel proceeding was however wholly owned by the Claimant in the proceeding where the objection was filed. Furthermore, the two disputes concerned the same facts, parties from the same country, the same type of issues. In both proceedings, the same law firm represented the respective Claimants. ${ }^{768}$

- The arbitrator was nominated by the same party in three related ICc cases involving the same counsel. ${ }^{769}$

- In two more instances, the arbitrators were nominated by the same party in parallel or subsequent related proceedings, and the respective counterparties argued that there would be an imbalance in the access to information. ${ }^{770}$

Objections to arbitrators' repeat nominations and challenges have been unsuccessful where the same parties are involved in all proceedings, and on both sides. For example, in a case in which the Claimants nominated the same arbitrator in three ICC proceedings, which involved the same parties and counsel on both sides, and which concerned different provisions of the same agreement, the ICc Court confirmed the arbitrator. Since the involved parties and counsel were identical in all three proceedings, the ICc Court held that there was no risk of an unequal access to information. ${ }^{771}$

B Familiarity with the Subject-Matter of the Proceeding

In general, in cases where - beyond the mere existence of a link between the arbitrator and a party or their counsel - the arbitrator (or a person close to him) has previously dealt with the subject-matter in dispute, the denial of the arbitrator's confirmation or his disqualification are certain. In the following cases, arbitrators were disqualified or not confirmed on such grounds:

\footnotetext{
767 Reiner and Aschauer, Art. 11, supra note 721, at 214.

768 Whitesell, supra note 719 , at 23 (case 5).

769 Jung, Comparative Study, supra note 680, at 25 (case 1).

770 Whitesell, supra note 719 , at 22 (cases 7 and 8).

771 Id. at 19 (case 7 ).
} 
- The arbitrator previously rendered legal advice to his appointing party, leading to the very contract at issue in the arbitration. ${ }^{772}$

- The arbitrator's colleague had advised the arbitrator's appointing party on the agreement at the center of the dispute. ${ }^{773}$

- The arbitrator was previously appointed by one of the parties as an expert in a judicial proceeding linked to the arbitration. The expert opinion he rendered was on the subject-matter of the dispute. ${ }^{774}$

- The arbitrator had formerly served as a mediator in the same dispute. ${ }^{75}$

If, however, the arbitrator has only made general statements about the subjectmatter, a non-confirmation or disqualification seems unlikely: In a case where the chairman had expressed political views in favor of one of the parties and against the home country of the other, the risk of a prejudgment was denied and the chairman confirmed. 776

C

Connection to an Adverse Third Party

Under the ICC Arbitration Rules, it is unclear under which circumstances an arbitrator's ties to a competitor or to a party that is otherwise opposed to one of the arbitration parties can justify their removal or the denial of their confirmation.

This question arose in Saudi Cable, ${ }^{777}$ where the chairman of the tribunal was a non-executive director of a major competitor of one of the arbitration parties. His company had been an unsuccessful bidder for the project which was at the core of the arbitration. The ICc Court dismissed the Claimant's challenge for unknown reasons. The Claimant applied to the English High Court for the arbitrator's removal, and failed. The subsequent appeal was equally unsuccessful. ${ }^{778}$ The English High Court Justices held that the requirement of independence only calls for "an absence of connection with either of the

772 Reported as "ICC Case - not disclosed" by Horvath and Berzero, supra note 37, at 11. See also Whitesell, supra note 719, at 29 (case 3).

773 Jung, Comparative Study, supra note 680, at 25 (case 3). The fact that he had drafted the agreement while working for another law firm did not make enough of a difference for the ICC Court to confirm his nomination.

774 Whitesell, supra note 719 , at 28 (case 1).

775 Reiner and Aschauer, Art. 11, supra note 721, at 210.

776 Whitesell, supra note 719 , at 32 (case 9).

777 AT\& Corporation and Lucent Technologies, Inc. v. Saudi Cable Company, ICC Case No. 8540.

778 AT\& T Corp. and another v. Saudi Cable Co. (Woolf, LJ, May 15, 2000) [2000] All ER (Comm) 201. 
parties in the sense of an absence of interest in, or of any present or prospective business or other connection with, one of the parties, which might lead the arbitrator to favor the party concerned."779

\subsection{Contextualization and Conclusion}

The above analysis of the three most important sets of commercial arbitration rules has shown that the abstract threshold for the disqualification of an arbitrator and its concrete application in certain constellations considerably depart from the ICSID case law. ${ }^{780}$

The disqualification of an arbitrator under any of the examined commercial arbitration rules requires justifiable or reasonable doubts about the arbitrator's independence or impartiality. ${ }^{781}$ No proof of an arbitrator's actual dependence or bias is required. Whether justifiable doubts arise in the specific circumstances of a case is examined from the vantage point of an objective third person under all of the covered arbitration rules.

The importance of an objective assessment has repeatedly been highlighted in past UNCITRAL disqualification decisions: Appointing authorities have stressed that they did not personally doubt the relevant arbitrator's independence or impartiality, but that this was not what mattered. Instead, what was decisive was whether the specific circumstances could create a reasonable perception of a lack of impartiality or independence. Appointing authorities deciding challenges under the UNCITRAL Arbitration Rules have also explicitly stated that a disqualification for prudential concerns may be warranted in certain cases, in order to protect the system's perceived legitimacy. ${ }^{782}$

The following spreadsheet provides an overview of the examined challenge decisions and visualizes the contrasting outcomes in investment and commercial arbitration. The case names of upheld challenges are underlined and in italics. Unnamed challenge decisions are marked $\circ$ for dismissed and $\bullet$ for upheld. Challenges marked with "R" (resignation) and "UT" (untimely) were not decided on the merits.

\footnotetext{
779 Id., referenced in SchWARTZ AND DERAINS, supra note 87, at 132.

780 Contra Reinisch and Knahr, supra note 24, at 121 ("[A]lthough the applicable standards ... differ markedly, in practice there seems to be a growing convergence. This is true even with regard to the different standards of assessing conflict of interest.").

781 The ICC Arbitration Rules do not clearly spell out the threshold applicable to arbitrator challenges. The reported disqualification decisions made under the ICC Arbitration Rules, however, are in line with decisions under the UNCITRAL and SCC Arbitration Rules, which explicitly stipulate a justifiable doubts threshold.

782 Bernasconi-Osterwalder, Johnson, and Marshall, supra note 32, at 9. See, e.g., Vito Gallo, II 18 and 33 .
} 
FIGURE 2 Outcomes of examined challenge decisions under the ICSID convention and commercial arbitration rules

Basis for Challenge

ICSID (Dismissed)

\begin{tabular}{llll}
\hline Familiar- & Contact & attorney-client relationship (between arbi- & Amco Asia \\
ity with a & with a Party & trator or his firm and party or related entity) & Vivendi \\
Participant & & & Lemire
\end{tabular}

representation of counterparty in previous or parallel proceeding

issuance of legal opinion for counterparty in parallel proceeding

counsel was adverse to the arbitrator in a proceeding against them personally merely occasional contacts Zhinvali

prior familiarity with a witness

previous public servant role

Generation Ukraine

former employee of subsidiary of a party

director of indirect controlling shareholder of party

Contact with affiliation of law firms (of arbitrator and Amco Asia a Counsel counsel)

or Law Firm

Representing a Party

previous collaboration (of arbitrator and

Universal counsel or law firm)

Compression (Tawil)

Nations Energy

Repsol (Wobeser) 


\begin{tabular}{|c|c|c|c|}
\hline ICsiD (Upheld) & UNCITRAL & scc & ICC \\
\hline \multirow[t]{8}{*}{ Blue Bank } & & $\begin{array}{l}\frac{60 / 1999}{53 / 2005} \\
\underline{68 / 2010} \\
170 / 2011 \\
\underline{174 / 2011} \\
\underline{177 / 2011} \\
78 / 2012 \\
\end{array}$ & $\begin{array}{l}\cdot \\
\cdot \\
\cdot \\
\cdot \\
\cdot \\
\circ(\text { no objection }) \\
\circ(\text { no objection }) \\
\circ\end{array}$ \\
\hline & $\begin{array}{l}\underline{\text { Grand River }} \\
\text { (cease either } \\
\text { role) } \\
\underline{I C S}\end{array}$ & $124 / 2011$ & \\
\hline & & $46 / 2007$ & $\circ$ \\
\hline & & $58 / 2008$ & \\
\hline & & $137 / 2008$ & \\
\hline & & & $\begin{array}{l}\circ \\
\circ \\
\circ\end{array}$ \\
\hline & & & • \\
\hline & & & $\bullet$ \\
\hline
\end{tabular}

Vannessa Ventures (R) 115/2010 
FIGURE 2 Outcomes of examined challenge decisions under the ICSID convention (cont.)

Basis for Challenge
ICSID (Dismissed)

confrontation in previous proceeding

membership in same British Chambers

shared educational history

Alpha Projektholding

arbitrator's company represented by same

counsel in unrelated proceeding

arbitrator's spouse is a partner in law firm

which nominated the arbitrator

issuance of legal opinions for parties repre-

sented by one of the counsels

former supervisor of the doctoral thesis of

a counsel

legal advice / counsel services to clients of a Total

law firm now representing a party
Role

Switching

Repeat Appointment
SGS

Azurix

Siemens

PIP

Repsol (Vicuña, Wobeser)

Suez I

by a party
Tidewater

Universal

Compression (Stern)

OPIC

Ickale

Saba Fakes

Electrabel 


ICSID (Upheld) UNCITRAL SCC ICC
$14 / 2004$
$1 / 2010$

ICC Case No. 16553

ICC Case No. 15860

$\circ$

o

\section{National Grid $\quad$ 10/200o}

\begin{tabular}{|c|c|c|c|}
\hline & National Grid & $10 / 2000$ & \\
\hline$\underline{\text { Caratube }}$ & $\begin{array}{l}\underline{\text { EnCana }} \text { (no } \\
\text { challenge) }\end{array}$ & $\begin{array}{l}14 / 2004 \\
18 / 2009\end{array}$ & $\begin{array}{l}\text { - (nominating party in } \\
\text { parallel proceeding wholly } \\
\text { owned by appointing party } \\
\text { in arbitration) } \\
\text { - } \\
\text { - } \\
\text { - } \\
\text { o (involved parties and } \\
\text { counsel identical in all } \\
\text { proceedings) }\end{array}$ \\
\hline
\end{tabular}


FIGURE 2 Outcomes of examined challenge decisions under the ICSID convention (cont.)

\section{ICSID (Dismissed)}

by a law firm / counsel

Tidewater

Universal

Compression (Stern)

OPIC

Ickale

Burlington (UT)

Rusoro

Caratube
Familiar-

ity with

Subject-

Matter

\section{Connection}

to Adverse

Third Party as an arbitrator

faced with same issues as a counsel

\section{Saint-Gobain}

Urbaser

academic publications

public speech

arbitrator or his law firm dealt with subjectmatter of specific dispute

arbitrator or his law firm dealt with subjectmatter of a related dispute

law clerk discussed legal questions online decision could impact parallel proceeding, in which arbitrator is a counsel

decision could impact parallel proceeding, Saint-Gobain in which related counsel is adverse to party Cemex (UT) 
UNCITRAL

SCC

ICC

$\underline{14 / 2004}$

\section{Cc/Devas}

(Lalonde,

Vicuña)

Telekom Malay-

$\underline{\text { sia }}$ (resign as a

counsel)

\section{Canfor (advice to \\ resign)}

$\underline{81 / 2012}$

$190 / 2010$

$148 / 2003$

Tanzania Electric (R)

S\&T Oil (R)

Eureko 
FIGURE 2 Outcomes of examined challenge decisions under the ICSID convention (cont.)

\section{Basis for Challenge}

ICSID (Dismissed)

$\begin{array}{ll}\text { relationship with firm adverse to a party } & \text { ConocoPhillips I } \\ & \text { Favianca (Mourre, R) } \\ & \text { Favianca (Fortier, UT) } \\ & \text { ConocoPhillips III } \\ \text { ConocoPhillips IV } & \text { ConocoPhillips V } \\ & \text { Favianca II } \\ \text { ConocoPhillips VI } \\ \text { Favianca III }\end{array}$

brother serves as arbitrator in parallel Getma proceeding

relationship with third party which is poten- EDF

tially interested in outcome of proceeding Suez I

simultaneous advice to potential third party

participant

director of major competitor of a party

Both under the SCC Arbitration Rules and under the ICC Arbitration Rules, contacts between a party and an arbitrator (or someone in the arbitrator's firm) are viewed more critically than under the ICSID Convention and Rules: Under the scc Arbitration Rules, practically all (reported) challenges based on such contacts have been upheld, even where these acquaintances were only superficial, infrequent or commercially insignificant, and even if the involvement in an unrelated and/or dissimilar case was at stake. ${ }^{783}$ This practice is considerably stricter than ICSID case law; so much that it raises the question where the de minimis threshold for a disqualification due to previous contacts lies:

[I]f a lawyer is to be considered disqualified as soon as the law firm where he or she practices has had any instructions from one of the parties, in

783 See, for example, Arbitration 6o/1999. 


ICSID (Upheld) UNCITRAL SCC ICC

$45 / 2008$

Suez II

Vito Gallo (cease

either role)

Saudi Cable

principle all lawyers at law firms would be barred from acting as arbitrators whenever a big company is party to the dispute. ${ }^{784}$

The case law under the ICC Arbitration Rules appears to be more balanced in this regard. When relationships between an arbitrator's firm and a party are at issue in a challenge, different factors are weighed, and the decision is made on a precautionary basis, to ensure the enforceability of the award. In particular, the ICC Court considers the timing of previous contacts, the proximity of the involved entities to the arbitrator or his law firm, the commercial significance of the relationship, and how closely related the matter was to the proceeding at issue. Even if only one of the criteria weighs in favor of a disqualification (i.e. if the contact was particularly recent), and a majority of the criteria indicate that the connection is innocuous, the challenge is

784 Mutis Tellez, supra note 604, at 11 (Arbitration 170/2011). 
upheld or the confirmation withheld. ${ }^{785}$ This approach is more lenient than that of the SCC Arbitration Rules, ${ }^{786}$ yet significantly stricter than the ICSID challenge case law.

Under all examined commercial arbitration rules, arbitrators were generally disqualified if they or their law firm previously had an attorney-client relationship with one of the arbitration parties or with an entity related to a party. ${ }^{787}$ This stands in contrast to the three ICSID cases in which such a connection was not considered to be a sufficient ground for disqualification..$^{788}$

The two case categories besides attorney-client relationships in which challenges have been raised and dismissed under the ICsID Convention and Arbitration Rules, namely occasional contacts between the arbitrator and a party, and the arbitrator's familiarity with a party due to his or her previous role as a public servant, have not been assessed differently in commercial arbitration. ${ }^{789}$

785 Schwartz AND Derains, supra note 87 , at 123 . The examined case law implies that a previous attorney-client relationship between the arbitrator and one of the parties or their counsel will lead to the arbitrator's disqualification in most cases. A very close personal relationship between an arbitrator and a counsel can also lead to a disqualification. A close working relationship between an arbitrator and a counsel or party, on the other hand, seems less problematic. There are however exceptions to this rule: In a case where the arbitrator was a former employee of a direct and an indirect subsidiary of a party, the ICC Court withheld his confirmation, although no objection was made, because his employment had lasted for a long time and had only just been terminated. See Jung, Comparative Study, supra note 680, at 25 (case 2).

786 Contra Jung, Comparative Study, supra note 68o, at 27 (holding that the ICC Arbitration Rules are, in principle, just as strict as the scc Arbitration Rules).

787 See scc Arbitrations 6o/1999, 53/2005, 68/2010, 170/2011, 174/2011, 177/2011, and 78/2012. See also Mutis Tellez, supra note 604, at 15 (referring to a "[c] onsistent scc practice of sustaining challenges based on the arbitrator's and/or his/her law firm's previous or current professional involvement with one of the parties."). In at least five reported ICC challenges, arbitrators were disqualified: See Whitesell, supra note 719, at 21 (case 4), 23 (case 3), and 29 (case 8); Reiner and Aschauer, Art. 11, supra note 721, at 210; Jung, Comparative Study, supra note 680, at 26 (case 4).

788 Amco Asia, Vivendi, and Lemire.

789 Under the ICc Arbitration Rules, current employees of the entity involved in the dispute, and civil servants otherwise involved with the subject-matter at issue will usually not be confirmed as arbitrators. Independent civil servants or former government employees, on the other hand, will usually be confirmed. This is in line with the ICSID challenge decision in Generation Ukraine. Where the arbitrator is neither a current employee of the involved State entity, nor otherwise involved with the subject-matter at issue, but has another, more indirect connection to the State, the decision is difficult to predict, and will often be influenced by pragmatic considerations, i.e. the ease with which the arbitrator could be substituted for an equally qualified arbitrator without a connection to the government. See Schwartz AND Derains, supra note 87, at 129-130. 
Challenges based on an arbitrator's representation of a counterparty in a previous or parallel proceeding have led to disqualifications in several UNCITRAL and SCC cases. Under the ICC Arbitration Rules, the issue is not settled yet - to date, only one of two such challenge cases (which were reported) has resulted in the arbitrator's disqualification. So far, no such case has been adjudicated under the ICSID Convention and Arbitration Rules - in S\&T Oil, the arbitrator voluntarily resigned. ${ }^{790}$

Previous contacts between an arbitrator (or their law firm) and a counsel are generally held to be unproblematic in commercial arbitration, as in ICSID arbitration. One exception is however worth highlighting: In an ICC case in which the arbitrator's law firm and the law firm representing one of the parties were in an alliance, the arbitrator was disqualified. The firms' sharing of office space in some locations and their organization of common seminars seemed to suffice to raise justifiable doubts about the arbitrator's independence and impartiality. This outcome stands in contrast to the dismissal of the challenge in Amco Asia, where the law firms had shared office space and administrative services for about half a year into the arbitration proceedings, and where a long-standing profit-sharing arrangement had been discontinued shortly before the arbitration was initiated.

With the exception of this deviation, the circumstances under which arbitrators have been challenged in the ICSID system have not triggered disqualifications under any of the examined commercial arbitration rules so far. In particular, the previous collaboration of an arbitrator and a counsel, or their shared educational history have not led to disqualifications under any of the examined arbitration rules. Disqualifications have generally only taken place under qualified circumstances, for example where the arbitrator's spouse was a partner in the law firm which had nominated him, ${ }^{791}$ and in a case where the arbitrator and counsel for one of the parties belonged to the same British Chambers and the place of arbitration was not London. ${ }^{792}$

Role switching appears to have been invoked as a basis for disqualification requests much more rarely in commercial arbitration than under the ICSID Convention and Arbitration Rules. To date, it has not led to the removal of an arbitrator.

Repeat appointments have most often been invoked as grounds for challenge where the same party repeatedly appointed the same arbitrator (shown in the

790 See supra Chapter 2, Part 2.4.

791 Reiner and Aschauer, Art. 11, supra note 721, at 210.

792 ICC Case No. 16553. In the context of the membership of an arbitrator and a counsel in British Chambers, the particularities of the case and the geographical setting appear to have a pivotal impact on the outcome of an objection or a challenge. See SCHWARTZ AND DERAINS, supra note 87 , at 126-127. 
spreadsheet as repeat appointments by a party). In contrast to ICSID case law, most of those challenges were upheld under commercial arbitration rules. ${ }^{793}$ Under the UNCITRAL Arbitration Rules, a tribunal even broached the issue in the absence of a challenge, and affirmed a risk of an inequality of arms. ${ }^{794}$

Challenges based on repeat appointments against a party have generally been dismissed. ${ }^{795}$ This is in line with the case law under the ICsID Convention and Rules.

In contrast to the ICSID challenge case law, one disqualification request based on the repeat appointment by a law firm was upheld under the SCC Arbitration Rules. ${ }^{796}$ Eight appointments by the same law firm within two years, of which five were still ongoing, were held to raise justifiable doubts about the arbitrator's independence and impartiality. This contrasts with the obiter dictum in Caratube, where the unchallenged arbitrators held that repeat appointments by the same law firm were not sufficient to infer a manifest lack of independence and impartiality, because they were unavoidable.

Under the ICC Arbitration Rules, repeat appointments have been held not to necessarily erode an arbitrator's independence. ${ }^{797}$ If, however, they are made in cases which concern the same particular or even general subject-matter, this might entail a risk of prejudgment, as well as an imbalance of knowledge on the tribunal. Accordingly, the confirmation of arbitrators has in the past been withheld when repeat appointments were made in multiple connected arbitrations, which raised identical issues, but where the parties were not the same. ${ }^{798}$

Looking at challenges based on the familiarity of an arbitrator with another participant in the proceeding in general, an important difference between ICSID and UNCITRAL decisions is the degree to which an overlap of the parties, facts and legal issues of the relevant cases is required. Under the ICSID Convention and Arbitration Rules, such challenges are generally dismissed, unless the parties, facts and legal issues of the relevant cases overlap to a significant degree. This is not the case under the UnCitral Arbitration Rules. In Grand River, for example, the indigenous land claim which was simultaneously pending before the Inter-American Commission on Human Rights was entirely

793 See SCC Arbitrations 14/2004 and 18/2009 and the ICC challenges reported in Whitesell, supra note 719, at 22 (cases 7 and 8), 23 (case 5); Jung, Comparative Study, supra note 680, at 25 (case 1 ).

794 See supra EnCana.

795 See National Grid and SCC Arbitration 10/2000.

796 See scc Arbitration 14/2004.

797 Schwartz and Derains, supra note 87 , at 127-128.

798 Id. at 129 . 
unrelated to the issues at stake in the UNCITRAL arbitration. In particular, the compliance of the United States with different international instruments was at issue. Nevertheless, the ICSID Secretary-General affirmed the "basic similarity" of the issues and held Professor Anaya's dual roles to be incompatible, highlighting that all proceedings concerned the compliance of the United States with "its international commitments."799 This "basic similarity" threshold is significantly lower than the virtual identity of cases required in ICSID disqualification proceedings. ${ }^{800}$

Moreover, since a complete overlap of the pertinent facts and legal bases is not required, the difficulty of assessing such an overlap before a case has fully been pleaded does not arise under the UNCITRAL Arbitration Rules. This makes it easier for parties to raise objections and make disqualification requests in a timely manner.

In the category of challenges based on a familiarity with the subject-matter at issue, most of the examined SCC and ICC cases concern arbitrators' (or their firms') previous involvement in the specific disputes at hand. In all of these cases, the arbitrators' confirmation was denied, or they were disqualified. To date, no such disqualification requests have been made under the ICsid Convention and Arbitration Rules.

Under the UnCIT RAL Arbitration Rules, disqualifications have also occurred where the arbitrator was not previously involved in the specific dispute, but dealt with the same legal questions in another setting - be it as a counsel, ${ }^{801}$ as an arbitrator, ${ }^{802}$ or in a political function. ${ }^{803}$ Although the challenged arbitrators' confrontation with the same legal questions in Saint-Gobain and Urbaser stemmed from different functions, these cases are comparable to the challenges under the UNCITRAL Arbitration Rules: In each of these constellations, valid concerns were to be weighed against arbitrator independence and impartiality. For example, the specialization of arbitrators (CC/Devas) and the interchangeability of their roles as arbitrators and counsel (Telekom Malaysia) are said to improve the flow of arbitration proceedings. ${ }^{804}$ The doctrinal discourse protected in Urbaser is an important motor to the development of international

\footnotetext{
799 Grand River, at 1.

800 See Mouawad, supra note 252, at 9; Fry and Stampalija, supra note 31, at 230.

801 See Telekom Malaysia I. Professor Emmanuel Gaillard was conditionally disqualified in this case. He would have been removed, if he had not resigned from his role as a counsel.

802 See the disqualification of Professor Francisco Orrego Vicuña in CC/Devas.

803 See Canfor, where the arbitrator was advised to step down, lest the ICsid Secretary-General uphold the challenge.

804 LUTTRELL, supra note 31, at 5 .
} 
law; and the involvement of previous public servants, as in Saint-Gobain, serves the interest of better understanding the positions of the involved Respondent States. These interests were however differently weighed against the requirement of impartiality in the two systems, leading to different results.

Connections to an adverse third party have been accepted as a basis for a disqualification in two of the examined UNCITRAL cases. ${ }^{805}$ In both cases, the arbitrator rendered legal advice in an unrelated matter to a third party which was potentially interested in the outcome of the proceeding. The challenged arbitrator's connection to the adverse third party in Saudi Cable was no less close, yet the disqualification request was dismissed, for lack of a direct connection between the arbitrator and one of the parties. ${ }^{806}$ Most ICSID challenges in this category were based on relationships to allegedly adverse third parties which were just as intense; ${ }^{807}$ nevertheless, all but one were dismissed.

In summary, the ICSID system imposes a heavier burden of proof and a higher challenge threshold than commercial arbitration rules on challenging parties. This still holds true today, despite the use of terminology which implies an alignment of the standards in recent ICSID challenge decisions.

In certain case categories, the available disqualification decisions under commercial arbitration rules are numerous and consistent enough to derive a practicable guidance as to which degree of proximity between an arbitrator and a party is acceptable. In particular, the inadmissibility of attorney-client relationships between an arbitrator or his or her law firm and a party or an entity related to it appears to be settled. The same can be said for repeat appointments by a party (depending, of course, on the number and frequency

805 Technically, the arbitrator in Vito Gallo was not disqualified, but was given the choice of ceasing either role. Had he not stepped down as Mexico's legal adviser, however, a disqualification would have ensued.

806 This argumentation by the English High Court is too narrow to do justice to the concepts of independence and impartiality. While independence concerns the relationship between the arbitrator and the parties, impartiality is broader. It requires the arbitrator to be free from any predisposition toward one of the parties or their argument. The proximity to an adverse third party, such as an important competitor, in particular, can clearly cause such a predisposition.

807 In EDF and Suez I, the challenged arbitrator was a director of the third party. In Getma, the arbitrator's brother was potentially adverse to the challenging party. In the ConocoPhilips and Favianca cases, the arbitrator's firm (from which he resigned in the course of the proceeding) targeted the law firm most adverse to one of the parties for a merger. In Cemex, finally, the arbitrator was a retired partner of the adverse law firm. The relationship between the arbitrator and the third party was only more remote in Saint-Gobain, where the arbitrator was a former co-worker of the adverse counsel. 
of the appointments), and for the arbitrator's (or his or her firm's) prior involvement in the subject-matter of the specific dispute. A category which is consistently considered to be unproblematic is the familiarity of an arbitrator with a party as a result of his or her former public servant role. The arbitrator's familiarity with a counsel only justifies his or her disqualification under qualified circumstances.

There are still, however, important case categories in which the outcome of a disqualification request is difficult to predict, because disqualification decisions are unavailable, scarce, or contradictory. The rendering of legal services to a counterparty in an unrelated proceeding, the repeat appointment against a party or by the same counsel or law firm, and connections to an adverse third party are examples of such unresolved scenarios.

\section{Self-regulatory Codes of Conduct for Arbitrators}

\subsection{Relevance}

Self-regulatory codes of conduct for arbitrators mainly differ from the arbitration rules examined above in that they are specifically enacted to govern arbitrators' conduct. They do not regulate arbitral proceedings as a whole, but only contain specific standards of adjudicators' ethics.

Furthermore, they are generally not binding, but only serve as guidelines. In practice, however, this differentiation is not as clear-cut. As will be laid out in more detail hereinafter, some self-regulatory codes of conduct have a rather far-reaching field of application, due to the lack of clarity and uniformity of existing (binding) arbitration rules. They often come into play when a conflict of interest is alleged, and as such, are an important source of standards of arbitrators' independence and impartiality.

Users of arbitration sometimes criticize self-regulatory codes of conduct for limiting what they perceive as their right to freely appoint a decision-maker. Proponents of the codes counter that the standards enounced in such instruments enhance parties' certainty that their appointee will remain on the arbitral tribunal. They make the criteria for assessing disclosure obligations, objections by the counterparty and challenges more transparent and predictable and render it more difficult for arbitrators or institutions dealing with such issues to pursue their own agenda. ${ }^{808}$ The legal certainty created by such

808 William W. Park, Arbitrator Integrity: The Transient and the Permanent, 46 SAN DiEgo L. REv. 629, 674 (2009) [hereinafter Park, Arbitrator Integrity]; Park, Arbitration's Discontents, supra note 24 , at 600 . 
instruments, it is argued, is in the interest of all participants of international arbitration, and justifies the self-regulation of the arbitration community.

The IBA Guidelines on Conflict of Interest in International Arbitration 809 are the most important and most frequently used such instrument - they will therefore be examined hereinafter. ${ }^{810}$

\subsection{The IBA Guidelines}

The IBA Guidelines were adopted by the Council of the International Bar Association in July 2004 and revised in October 2014. They apply to international commercial arbitration as well as to international investment arbitration. 811 Their promulgation was driven by the realization that existing standards of independence and impartiality lacked clarity and uniformity. The IBA Guidelines aim to increase both, and to thereby reduce the number of unnecessary disclosures and withdrawals. ${ }^{812}$ The overarching goal of the Guidelines is to protect the integrity of international arbitration. ${ }^{813}$

Initially, the IBA Guidelines earned a lot of criticism for being too burdensome $^{814}$ and strict, and for enabling opportunistic parties to delay and derail proceedings. ${ }^{815}$ This criticism has however largely died down and the IBA

8 о Hereinafter the гва Guidelines. The гва Guidelines are not to be confused with the гвА Rules of Ethics for International Arbitrators, which only stipulate a broad obligation to be competent, diligent, efficient and to remain "free from bias." See IвA Rules of Ethics for International Arbitrators (1987), rules 1, 2; Park, Arbitration's Discontents, supra note 24, at 6oo-6o1, note 55 .

810 Specific codes of ethics for international arbitrators have been introduced by newer regional arbitral institutions. See, e.g., Milan Chamber of Commerce, International Arbitration Rules: Code of Ethics for Arbitrators (2010), available at http://www.camera-arbitrale .it/Documenti/cam_arbitration-rules_2010.pdf (last accessed on Dec. 30, 2016); Singapore International Arbitration Centre, Code of Practice: Code of Ethics for an Arbitrator (2009), available at http://www.siac.org.sg/our-rules/code-of-ethics-for-an-arbitrator (last accessed on Dec. 30, 2016). See Rogers, Ethics, supra note 98, ๆ

811 IBA Guidelines, Introduction, para. 5 .

812 IBA Conflict of Interests Subcommittee, supra note 672 , at 5 . Ball, supra note 45, at 323; Leon Trakman, The Impartiality and Independence of Arbitrators Reconsidered, 10 INT'L.

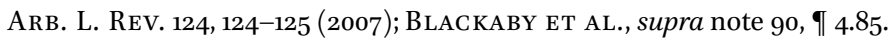

813 David A. Lawson, Impartiality and Independence of International Arbitrators - Commentary on the 2004 IBA Guidelines on Conflicts of Interest in International Arbitration, 23 ASA BuLlETIN 22, 36 (2005); Trakman, supra note 812, at 129 (adding efficiency to the list of regulatory intents of the гва Guidelines).

814 See Ramon Mullerat ове, Arbitrators' Conflicts of Interest Revisited: A Contribution to the Revision of the Excellent IBA Guidelines on Conflicts of Interest in International Arbitration, 4 Disp. Resol. InT'L. 55 (2010).

815 Trakman, supra note 812, at 125 (stating that the Guidelines "opened the door to both opportunity and opportunism"). 
Guidelines have gained wide acceptance in the international arbitration community. Although the Guidelines are technically non-binding, ${ }^{816}$ they are increasingly seen as representing good practice ${ }^{817}$ and therefore widely used..$^{818}$

In commercial arbitration, they are routinely applied by arbitrators when considering an appointment, deciding whether to make a disclosure, or when ruling on a disqualification request. Counsel and parties in commercial arbitration rely on the IBA Guidelines when deciding whether to challenge an arbitrator, and even arbitral institutions and courts increasingly invoke them when ruling on challenges to arbitrators and awards. ${ }^{819}$ The sCc Board, for example, often references the IвA Guidelines and considers them officially applicable to challenges under the SCC Arbitration Rules. The ICC Court has repeatedly stated that it does not consider the IBA Guidelines to be binding, but in practice, the ICC Secretariat usually references them as persuasive authority in its briefing of the ICC Court on challenges. ${ }^{820}$ ICSID tribunals, in contrast, still persistently highlight that they are not bound by the IBA Guidelines, ${ }^{821}$ although the Guidelines are regularly relied upon by parties. ${ }^{822}$

The IвA Guidelines are construed in two parts. The first part enounces the principles - the General Standards - to be kept in mind by arbitrators, parties and institutions when deliberating on (alleged) bias. Every General Standard is accompanied by an explanatory note, which outlines the observations and regulatory intent of the Working Group. The General Standards are then followed by (non-exhaustive) lists of specific conflict situations for practical guidance (the Application Lists) in Part two. The color (red, orange or green) of the respective Application List indicates whether a disclosure or a disqualification is or is not warranted in light of the specific situation: In the situations listed on the Red List, arbitrators should decline their appointment, or withdraw. The Orange List enumerates situations which may give rise to justifiable doubts as to the arbitrator's impartiality or independence, and which must therefore be disclosed to the parties. If, upon said disclosure, the parties do not object to the arbitrator's involvement within thirty days, they are deemed to have waived

816 Bernasconi-Osterwalder, Johnson, and Marshall, supra note 32, at 29.

817 Sheppard, supra note 32, at 136; Bernasconi-Osterwalder, Johnson, and Marshall, supra note 32 , at 29 .

818 Rogers, ETHICs, supra note 98, ๆ 2.87 and 6.75; Trakman, supra note 812, at 126 (pointing out the "subtly peremptory" nature of the Guidelines).

819 IBA Guidelines, at i; Rogers, Етнics, supra note 98, ๆ 2.86.

820 IBA Conflict of Interests Subcommittee, supra note 672, at 29 ("According to the ICC, in 106 of the 187 cases, at least one article of the Guidelines was referred to as potentially contemplating the situation" - in a vast majority of cases, the basis for the challenge was covered by the Orange List).

821 ConocoPhillips $I$, at 59 .

822 IBA Conflict of Interests Subcommittee, supra note 672 , at 37 . 
their right to a challenge. Finally, the Green List describes situations in which neither a disclosure nor withdrawal is advised.

The core content of the General Standards and Application Lists is briefly outlined hereinafter.

General Standard 1 very generically stipulates the obligation of independence and impartiality:

Every arbitrator shall be impartial and independent of the parties at the time of accepting an appointment to serve and shall remain so until the final award has been rendered or the proceedings have otherwise finally terminated.

General Standard 2 specifies the vantage point and threshold for the examination of a potential conflict of interest. An arbitrator shall forego his appointment or resign if he personally doubts, or if an informed reasonable third person would justifiably doubt his ability to act independently and impartially. ${ }^{823}$ The vantage point for the assessment of challenges is thus an objective one. ${ }^{824}$ The threshold for affirming justifiable doubts is remarkably low: The mere likelihood of external factors influencing the arbitrator's decision-making is sufficient. 825

General Standard 3 governs the disclosure of potential conflicts of interest. Since the disclosure obligation is less intrusive than a disqualification or an obligation to resign, ${ }^{826}$ it makes sense that the threshold stipulated in General Standard $3(\mathrm{a})$ is lower: Arbitrators are required to disclose all circumstances which may - "in the eyes of the parties" - raise doubts about their impartiality or independence. Unlike the objective (reasonable third person) standard in General Standard 2, this test is a subjective one. It favors transparency, as does the presumption in favor of disclosure provided for in General Standard $3(d)$.

General Standard 6 mentions various situations in which the connection between an arbitrator and a party is indirect, and the assessment of independence and impartiality is therefore more difficult: One of the parties (or a company

823 IBA Guidelines, General Standards 2(a) and (b).

824 Horvath and Berzero, supra note 37, at 5; Park, Arbitration's Discontents, supra note 24, at 601 .

825 IBA Guidelines, General Standard 2(c). The explanation to General Standard 2 does not elaborate on this choice of wording. In the situations described in the Non-Waivable Red List (see infra Part 3.2 B.), doubts are always justified, and arbitrators are accordingly required to resign (IBA Guidelines, General Standard 2(d)).

826 IBA Guidelines, General Standard 3(c) (clarifying that a disclosure does not prejudice the outcome of a potential challenge). 
in the same group) may be involved in the activities of the arbitrator's law firm, or an arbitrator or his firm may have a connection with a physical person who has a controlling influence on one of the parties, or a direct economic interest in the outcome of the proceeding. Unfortunately, the IвA Guidelines provide no concrete guidance on the assessment of such constellations, besides stating that the connections of related third parties may be taken into account, and that the facts of each individual case have to be considered. If anything, the IBA Guidelines are rather lenient on this point, stating explicitly that "activities of the arbitrator's firm should not automatically create a conflict of interest." ${ }^{827}$

The Application Lists are generally considered to be one of the most useful features of the IвA Guidelines. They illustrate the weighting of opposing interests (on the one hand, procedural economy and the parties' right to freely chose an arbitrator, and on the other hand, the greatest possible independence and impartiality of the decision-maker) by categorizing potential conflict situations according to their level of sensitivity and by providing for commensurate legal consequences, ranging from disclosure to disqualification or resignation. ${ }^{828}$ Where parties, arbitrators or arbitration institutions are faced with a situation explicitly provided for in a list, their decisions regarding a resignation, a challenge or a removal are directly facilitated by the IBA Guidelines. The IBA Guidelines are unique and novel in their nuanced and practical approach to frequently occurring conflict situations.

Beyond providing for the legal consequences in anticipated situations, however, they are also a useful guideline for the evaluation of situations which were not borne in mind when the IвA Guidelines were drafted. The weighting expressed by the categorization provides a more accurate guideline than the abstract standards and thresholds for arbitrator challenges contained in the General Standards or in the arbitration rules described above, in Chapter 3, Part 2.

The Non-Waivable Red List enumerates four instances of obvious selfinterest of the arbitrator in the outcome of the proceeding, based on his or her relationship with one of the parties:

1. Non-Waivable Red List

1.1 There is an identity between a party and the arbitrator, or the arbitrator is a legal representative or employee of an entity that is a party in the arbitration.

\footnotetext{
827 IBA Guidelines, Explanation (a) to General Standard 6 (emphasis added). See also Bernasconi-Osterwalder, Johnson, and Marshall, supra note 32, at $3^{1}$ (arguing that General Standard 6 "tacitly recogniz[es] and approv[es] the dual arbitrator / counsel role").

828 Park, Arbitration's Discontents, supra note 24, at 601.
} 
1.2 The arbitrator is a manager, director or member of the supervisory board, or has a controlling influence on one of the parties or an entity that has a direct economic interest in the award to be rendered in the arbitration.

1.3 The arbitrator has a significant financial or personal interest in one of the parties, or the outcome of the case.

1.4 The arbitrator or his or her firm regularly advises the party, or an affiliate of the party, and the arbitrator or his or her firm derives significant financial income therefrom.

These situations are considered to be so contrary to the principle of nemo iudex in causa sua (no one can be his or her own judge), that even a formalized and informed consent of the parties does not cure the conflict - the respective arbitrator must resign or will be disqualified. ${ }^{829}$ Because of the intrusiveness of this legal consequence, only the most striking scenarios are included in the Non-Waivable Red List. Some are further qualified using descriptors such as "significant" or "regularly." While these terms intend to restrict the scope of application of the Non-Waivable Red List, the ample room for interpretation they create also entails a risk of unpredictability. 830

The constellations listed in the Waivable Red List are still serious, but not quite as severe. ${ }^{831} \mathrm{~A}$ conflict of interest will therefore be presumed, and the arbitrator disqualified, unless all parties agree on an express and fully informed waiver of their right to challenge the respective arbitrator. ${ }^{832}$ The degree of proximity between the arbitrator and the other participant in the proceeding is generally very high in the listed constellations.

Examples of covered situations are an arbitrator's prior involvement in the specific dispute (inter alia by rendering legal advice) ${ }^{833}$ and certain forms of (direct or indirect, financial or personal) interest in the outcome of the dispute, such as shareholdings in one of the parties, ${ }^{834}$ or the arbitrator's (or a close family member's) significant financial interest in the outcome of the

829 IBA Guidelines, General Standard 2(d) and Introduction to the Application Lists, ๆ 2.

830 See Mullerat ове, supra note 814, at 61 and 67. For example, it is argued that para. 1.3 should apply to investment arbitrators who are simultaneously acting as counsel in other investor-State disputes involving similar issues, since they have a significant personal and professional interest in creating a useful precedent for that second case (even more so if services in that case are rendered on a contingency fee basis). See BernasconiOsterwalder, Johnson, and Marshall, supra note 32 , at 32.

831 I

832 See also General Standard 4(c).

833 IBA Guidelines, Application Lists, $\S \S 2.1 .1$ and 2.1.2.

834 IBA Guidelines, Application Lists, § 2.2.1. 
dispute. ${ }^{835}$ Certain non-exhaustively enumerated relationships with a party or its counsel ${ }^{836}$ are also on the Waivable Red List.

The Orange List is the most extensive of all Application Lists. It enumerates situations which may, in the eyes of the parties, give rise to doubts as to the arbitrator's independence and impartiality, and requires arbitrators to disclose any such situation. The disclosure triggers a thirty day delay to challenge the arbitrator, after which the right to challenge is presumed to have been waived. The inclusion of a particular constellation in the Orange List does not prejudice the success of a respective challenge - not even in the event of an arbitrator's failure to disclose the potential conflict of interest. In contrast to the constellations included in the Red Lists, a request for disqualification based on a (disclosed or undisclosed) Orange List situation will be evaluated in the light of General Standard 3(a), thus requiring an objective determination of justifiable doubts as to the arbitrator's independence and impartiality.

The following three examples offer a glimpse of the long list of constellations covered by the Orange List: Firstly, an arbitrator who was personally (or whose firm was) involved in an unrelated matter concerning a party or one of its affiliates within the past three years falls under the Orange List. ${ }^{837}$ Secondly, two or more repeat appointments by a party or an affiliate (or more than three by the same counsel) within the past three years trigger the application of the Orange List. ${ }^{838}$ Thirdly, if the arbitrator has within the last three years served, or is currently serving as an arbitrator in a related case involving one of the parties or an affiliate, the situation is also covered by the Orange List. ${ }^{839}$

As these examples illustrate, the Orange List explicitly enumerates situations where a very recent (or simultaneous) and relatively close connection between an arbitrator and a party exists. This raises the question whether connections which are more remote, or contacts which fall outside the indicated three year time frame, are automatically innocuous. The answer is no. The high level of detail of the descriptions of proximity and the time frames in the Orange list should not distract from the fact that this Application List is non-exhaustive. Situations which are seemingly not covered by the Orange List, because they are not expressly provided for, are subject to General Standard 2, and while they might generally not be problematic, they must be assessed on a case-by-case basis. ${ }^{840}$

\footnotetext{
835 IBA Guidelines, Application Lists, $§$ 2.2.2.

836 IBA Guidelines, Application Lists, § 2.3.

837 IBA Guidelines, Application Lists, §§ 3.1.1, 3.1.2., and 3.1.4. It is irrelevant whether the attorney-client relationship was with the party or with its adversary.

838 IBA Guidelines, Application Lists, § 3.1.3.

839 IBA Guidelines, Application Lists, § 3.1.5.

840 IBA Guidelines, Introduction to the Application Lists, 96 .
} 
Finally, the Green List is a non-exhaustive list of circumstances in which it is presumed that no actual or apparent lack of independence and impartiality exists from an objective point of view. Thus, no disclosure is required and a challenge will normally fail. Interesting (and controversial) constellations contained in this list are the previous expression of legal opinions on issues that arise in the dispute, but without reference to the respective case, and the previous service of an arbitrator and a counsel as co-arbitrators.

Being a reflection of international principles and best practices, and an international self-regulatory compromise ${ }^{841}$ a certain vagueness of the Application Lists is said to be unavoidable. ${ }^{842}$ This vagueness, however, limits the usefulness of the Lists, since it endangers their coherent interpretation and application. It enables litigious counsel to file tactical challenges and to thereby obstruct proceedings. ${ }^{843}$ Accordingly, the vague and circumlocutory language of the Application Lists impedes procedural efficiency and jeopardizes arbitrators' and arbitration's reputation. On the other hand, when applied to limit the scope of the Red and Orange Lists, the same language causes arbitrators not to be held to a sufficiently high standard of independence and impartiality. ${ }^{844}$ Accordingly, the vagueness of the Application Lists serves neither the interest of the greatest possible independence and impartiality of arbitrators, nor the interest of procedural efficiency and party autonomy.

C

\section{Case Law}

The IBA Guidelines do not supersede but only supplement the otherwise applicable provisions on conflicts of interest. Therefore, decisions which were governed by rules other than the ICSID Convention and Arbitration Rules, and in which the IBA Guidelines were applied are classified above, under the respective arbitration rules.

Within the ICSID framework, there have so far only been two published challenges in which the parties agreed on the application of the IBA Guidelines. In Perenco, ${ }^{845}$ Respondent challenged the Claimant-appointed arbitrator, the

841 Mullerat ОВЕ, supra note 814 , at 57 .

842 IBA Guidelines, Introduction to the Application Lists, 9 8: "[T] he Lists contain, for various situations, general terms such as 'significant' and 'relevant'. The Lists reflect international principles and best practices to the extent possible. Further definition of the norms, which are to be interpreted reasonably in light of the facts and circumstances in each case, would be counterproductive."

843 Trakman, supra note 812 , at 124, 130; Mullerat OBE, supra note 814, at 59 .

844 Mullerat ОвЕ, supra note 814, at 61-62 (criticizing the IвA Guidelines' "pro arbitro attitude").

845 Perenco Ecuador Limited v. The Republic of Ecuador \& Empresa Estatal Pertoleos Del Ecuador (Perenco), ICSID Case No. ARB/o8/6, Decision of the Secretary-General of the Permanent Court of Arbitration on a Challenge an Arbitrator, PCA Case No. IR-2009/1 (Dec. 8, 2009). 
Hon. Charles N. Brower, for making comments about the pending proceeding and about Respondent in a published interview. The statement that triggered the challenge was the following:

Editor: Tell us what you see as the most pressing issues in international arbitration.

Brower: There is an issue of acceptance and the willingness to continue participating in it, as exemplified by what Bolivia has done and what Ecuador is doing. Ecuador currently is expressly declining to comply with the orders of two ICSID tribunals with very stiff interim provisional measures, but they just say they have to enforce their national law and the orders don't make any difference. But when recalcitrant host countries find out that claimants are going to act like those who were expropriated in Libya, start bringing hot oil litigation and chasing cargos, doing detective work looking for people who will invoke cross-default clauses in loan agreements, etc., the politics may change. After a certain point, no one will invest without having something to rely on. ${ }^{846}$

Applying an "objective" appearance of bias standard, the Secretary-General of the $\mathrm{PCA}^{847}$ examined whether "a reasonable and informed third party [could] conclude that there is a likelihood that Judge Brower may be influenced by factors other than the merits of the case as presented by the parties in reaching his decision." ${ }^{848}$ In view of the wording chosen by Judge Brower (the association of the pejorative term "recalcitrant" with the Respondent) and the context of his statement, the question was answered in the affirmative. The comparison of the conduct of Ecuador with that of Libya in the 1970s, in particular, could lead a reasonable third party to doubt the arbitrator's open-mindedness with regard to the allegation of expropriation and Ecuador's willingness to abide by an arbitral award. Moreover, the Secretary-General of the PCA held that since the Judge made those comments as a response to the interviewer's question about the "most pressing issues in international arbitration," it could be inferred that he considers Ecuador's behavior to be of such gravity as to represent one of the most important challenges in international arbitration. ${ }^{849}$ The Secretary-General of the PCA dismissed the Claimant's argument that the arbitrator's statements should be examined in the light of his "experience and

\footnotetext{
846 Perenco, 927.

847 The disputing parties in the case had expressly agreed that arbitrator challenges should be decided by the Secretary-General of the PCA. See Id. 12.

848 Id. ๆ 943 and 46 .

849 Id. $ๆ$ ๆ $48-52$.
} 
standing." Since there was nothing in the IBA Guidelines supporting a special deference to an arbitrator's experience or reputation, it was held that those factors were irrelevant. ${ }^{850}$ In other words, experienced and well-known arbitrators do not get the benefit of the doubt.

It is also noteworthy that the Secretary-General of the PCA explicitly noted that other interpretations of the arbitrator's statements would ("of course") have been possible, but that the described interpretation, which raised doubts as to the arbitrator's impartiality, was a reasonable one. ${ }^{851}$ This sufficed for a disqualification. In other words, the understanding which leads to the doubts need not be the only possible or the most obvious interpretation - it merely needs to be justified in the eyes of a reasonable third person.

In Highbury, ${ }^{852}$ Professor Brigitte Stern was challenged by the investor, based on her repeat appointments by Venezuela and by the law firm Foley Hoag LLP (Foley Hoag). Within the last five years, Venezuela had appointed her in five cases (once within the past three years), and Foley Hoag had done so in six cases (twice within the last three years). ${ }^{853}$

The unchallenged arbitrators applied $\S \S 3.1 .3$ and 3.3.8 of the IBA Guidelines' Application List, but highlighted that the time frames stated in these provisions would have to be longer in investment treaty arbitration, since public interests were at stake. Furthermore, they stressed that the numbers of appointments and time frames in $\S \S 3.1 .3$ and 3.3.8 of the Application List were not authoritative thresholds in a strict sense. While exceeding them could surely raise doubts as to the arbitrator's independence and impartiality, falling short of those parameters would not necessarily exonerate her. ${ }^{854}$ Disqualification requests should not be approached as if they were a matter of statistical analysis, since numbers can be deceiving. Instead, all relevant factors would have to be taken into account; for example the nomination dates, the current status of the other proceedings (ongoing or terminated), any jurisdictional or substantive decisions, dissenting opinions rendered in favor of the appointing party and the proportion of cases referred to the arbitrator by the appointing party, compared to the arbitrator's entire caseload. ${ }^{855}$ Every nomination would have to be examined in detail, and pursuant to these criteria.

The unchallenged arbitrators then went on to analyze the specific allegations against Professor Stern. They established that the thresholds in $\S \S 3.1 .3$

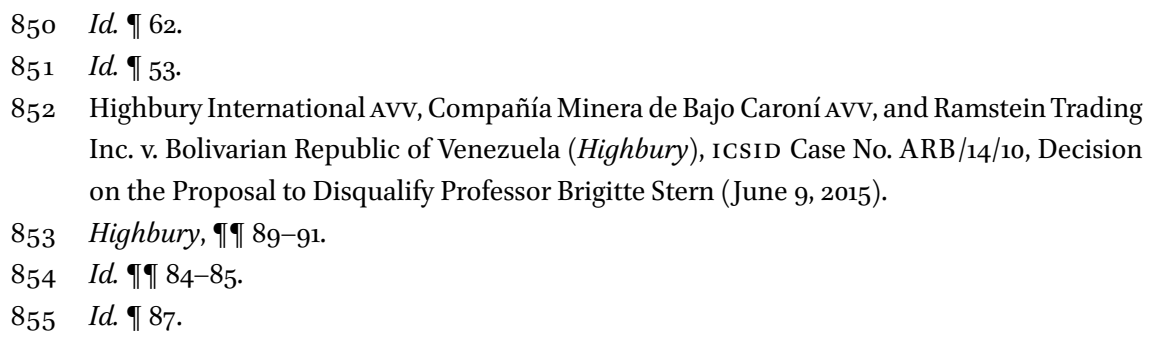

852 Highbury International Avv, Compañía Minera de Bajo Caroní Avv, and Ramstein Trading Inc. v. Bolivarian Republic of Venezuela (Highbury), ICsID Case No. ARB/14/10, Decision on the Proposal to Disqualify Professor Brigitte Stern (June 9, 2015).

853 Highbury, ๆ 9 89-91.

854 Id. ๆף $84-85$.

855 Id. ๆ 87. 
and 3.3.8 of the Application List were not exceeded. Considering all appointments, beyond the three year limit, ${ }^{856}$ the unchallenged arbitrators concluded that the repeat appointments were not sufficient to justify Professor Stern's disqualification. ${ }^{857}$ They highlighted, in particular, that the nine appointments by Venezuela and Foley Hoag needed to be seen in relation with the total of seventy or eighty arbitrations in which she has participated, of which fiftyseven were administered by ICSID. Furthermore, four of the nine nominations had been made more than five years ago, and only five of the arbitrations were still ongoing. Also, Professor Stern had never issued a dissenting opinion. ${ }^{858}$ A potential issue conflict could not be considered at this point of the proceeding, since the case had not entirely been pleaded yet. ${ }^{859}$ The apprehension that Professor Stern could form an opinion in Highbury based on evidence submitted in one of the other cases was held to be unfounded, since the tribunal could not decide based on documents which were not on the record. ${ }^{860}$

\subsection{Contextualization and Conclusion}

The IвA Guidelines are undeniably innovative in their practical approach of listing specific situations which might lead conflicts of interests, and color-coding them according to their level of sensitivity. At first sight, this approach is more nuanced and instructive than an abstract qualitative ${ }^{861}$ standard, and promises to achieve a more uniform case law on arbitrator challenges. On closer inspection, however, it is questionable whether the IBA Guidelines would enhance the predictability of challenge decisions in the investment arbitration context.

First, the Іва Guidelines provide clear and helpful guidance regarding the obligation to disclose, but remain inconclusive for most challenges. Only in a tiny minority of situations is the outcome of a disqualification request predictable, because the situation is either mentioned in a Red List (which entails at least a presumption of disqualification), or on the Green List (which normally excludes disqualification). In all other constellations, it is either unclear which list is relevant, or the Orange List is pertinent. Since the Red Lists are very narrowly tailored, while the Orange and Green Lists are more extensive and nonexhaustive, there is much room left for uncertainty. Indeed, the predictability of the outcome of a challenge is not the rule, but the exception. The vagueness of certain provisions of the Application Lists further aggravates this insecurity.

\footnotetext{
$856 \quad$ Id. 995 .

$857 \quad I d .999$.

$858 \quad I d .998$.

$859 \quad I d .9106$.

86o Id. ๆ 107 ("ningún tribunal puede decidir sobre la base de documentos que no se encuentran en el expediente.").

861 See Rogers, Ethics, supra note 98, ๆ 6.69.
} 
In situations which cannot be assigned to either the Red or the Green Lists, the success of a disqualification request will depend on the finding of justifiable doubts as to the arbitrator's independence and impartiality. The parties, arbitrators as well as the authority deciding on the challenge are thus relegated to the abstract, qualitative standard which was meant to be put in more concrete terms in the Application Lists, and the outcome of the challenge remains unpredictable.

Second, it appears that the particularities of investment arbitration were to a certain extent sidelined when the IвA Guidelines were drawn up. ${ }^{862} \mathrm{Al}-$ though the Guidelines are said to have been designed with commercial and investment arbitration in mind, they fail to mention some situations which are frequently invoked as grounds for challenges in investment arbitration. ${ }^{863}$ For example, the arbitrator's previous employment as a public servant (and her or his ensuing familiarity with the State party or with the subject-matter of the case), ${ }^{864}$ and role switching, ${ }^{865}$ are not covered by the Application Lists. While it is possible to resolve such challenges by subsuming the situations under the General Standards of the ІвА Guidelines, the advantage of predictability and uniformity is thereby lost.

Furthermore, the valuations underlying the Application Lists are not always suitable in the investment arbitration context. For example, the Green List includes previously expressed legal opinions concerning an issue relevant in the arbitration, which were made without reference to the arbitration. ${ }^{866}$ In investment arbitration, however, such statements might be more problematic, due to the narrower, more repetitive set of issues at the center of such disputes. ${ }^{867}$ The threshold numbers and timeframes for repeat appointments to be covered by the Orange List ${ }^{868}$ might also have to be reconsidered in the context of ICSID: Since the system as a whole (caseload, number of actors, number of potential parties) is smaller than commercial arbitration, fewer reappointments can entail a higher risk to arbitrators' independence. ${ }^{869}$

862 The IвA Guidelines are not simply the "product of an objective application of technical expertise to the problem of arbitrator conflicts," but, as a global regulatory process, their drafting had "important distributional implications, generating winners and losers." See Rogers, ETHICs, supra note 98, $₫ 6.80$.

863 Mouawad, supra note 252, at 1.

864 See the challenge decisions in Generation Ukraine and Saint-Gobain.

865 See the challenge decisions in sGs, Azurix and Siemens.

866 IBA Guidelines, Application Lists, § 4.1.1.

867 See also Rubins and Lauterburg, supra note 32, at 164.

868 IBA Guidelines, Application Lists, §§ 3.1.3, 3.3.8, and 3.1.5.

869 In Highbury, the unchallenged arbitrators held that longer timeframes were appropriate in investment arbitration, since public interests were at stake ( $(84)$. 
Third, even if the particularities of investment arbitration are factored out, the IBA Guidelines appear very lenient in their classification of certain conflict categories. Only the most striking examples of an arbitrator's obvious self-interest and highly likely bias are included on the Red Lists, while certain constellations in which disqualifications have occurred in commercial arbitration are not included. For example, challenges based on repeat appointments which do not fall within the narrow parameters of the IBA Guidelines' Orange List $^{870}$ have been upheld under the $\mathrm{SCC}^{871}$ and ICC Arbitration Rules. ${ }^{872}$ Similarly, attorney-client relationships with a party which would not be covered by the IвA Guidelines' Red List ${ }^{873}$ have consistently been accepted as a basis for disqualification under the SCC $^{874}$ and ICC Arbitration Rules. ${ }^{875}$ Even the few cases in which ICSID arbitrators were disqualified would not fall under the Red Lists, but only under the Orange List. ${ }^{876}$ In these categories, the IBA Guidelines do not achieve their goal of enhancing predictability and uniformity.

Indeed, the narrow construction of the IвA Guidelines' Red Lists and the relatively high threshold imposed by the Orange List could be interpreted to express an underlying presumption against disqualification. While such a presumption would be at odds with General Standards 2 and $3(\mathrm{~d})$, the weighting of conflicting interests inherent in the Application Lists and transpiring from the framework is likely to influence arbitration users' approach to challenges. Such an effect would be undesirable.

The following charts illustrate the (hypothetical) application of the IвA Guidelines' Application Lists to the ICSID challenges analyzed in Chapter 2, and corroborate the above objections.

Most situations which have been invoked as grounds for ICSID challenges would fall under the Orange List, or are not expressly provided for in the Application Lists, and are difficult to classify by analogy. In these cases, it is unclear how the challenge would have been decided:

870 Repeat appointments are only mentioned in the Orange List, and only trigger the arbitrator's disclosure obligation in narrowly delineated circumstances: Within the past three years, the arbitrator must have been appointed by the same party (or its affiliate) on two or more occasions, by the same counsel or law firm on three or more occasions, or in a related proceeding involving one of the parties (or an affiliate) in at least one instance. See IBA Guidelines, Application Lists, §§ 3.1.3, 3.3.8, and 3.1.5.

871 Öhrström, supra note 45, at 42-46 (sCC Arbitration 10/200o).

872 See supra Part 2.4 A.

873 IBA Guidelines, Application Lists, § 2.3.1. Unless the arbitrator personally is currently advising the party or its affiliate, the situation is only covered by $\S 3.1 .4$ of the Orange List.

874 See supra Part 2.3 A.

875 See supra Part 2.4 A.

876 Vannessa Ventures would fall under $§ 3.3 .9$ of the Application Lists, while Caratube would be covered by $\S 3.3 .8$. 
Basis for Challenge

$\begin{array}{lll}\begin{array}{l}\text { Familiarity with } \\ \text { a Participant }\end{array} & \text { Contact with a Party } & \begin{array}{l}\text { attorney-client relationship } \\ \text { (between arbitrator or his firm and } \\ \text { party or affiliate) }\end{array}\end{array}$

Contact with a Counsel or previous collaboration (of

Law Firm Representing a arbitrator and counsel or law firm)

Party

Repeat Appointment

against a party

by a party or by a law firm /

counsel

Connection to

Adverse Third

Party decision could impact parallel

proceeding, in which arbitrator

is a counsel

decision could impact parallel

proceeding, in which related

counsel is adverse to party

merger with firm adverse to a

party 


$\begin{array}{llll}\text { ICSID Case } & \text { Outcome } & \text { Relevant } & \text { Hypothetical } \\ \text { under ICSID } & \text { Provision in IBA } & \text { Outcome under IBA } \\ \text { Convention \& } & \text { Guidelines } & \text { Guidelines } \\ \text { Rules } & & \end{array}$

\begin{tabular}{|c|c|c|c|}
\hline Amco Asia & dismissed & 3.1 .4 & \multirow{3}{*}{$\begin{array}{l}\text { depending on } \\
\text { finding of justifiable } \\
\text { doubts }\end{array}$} \\
\hline Vivendi & dismissed & 3.1 .4 & \\
\hline Lemire & dismissed & 3.1 .4 & \\
\hline
\end{tabular}

\begin{tabular}{|c|c|c|c|}
\hline Universal Compression & dismissed & $3 \cdot 3 \cdot 9$ & depending on \\
\hline Nations Energy & dismissed & $\begin{array}{l}3 \cdot 3 \cdot 3 \text {, if within } \\
\text { time frame }\end{array}$ & $\begin{array}{l}\text { finding of justifiabl } \\
\text { doubts }\end{array}$ \\
\hline
\end{tabular}

\begin{tabular}{llll}
\hline Vannessa Ventures & resignation & $3 \cdot 3 \cdot 9$ & \\
PIP & dismissed & 3.1 .5 , if cases depending on
\end{tabular}

PIP dismissed $\quad \begin{array}{ll}3.1 .5 \\ \text { related }\end{array} \quad$ depending on

\begin{tabular}{lll} 
& related & $\begin{array}{l}\text { finding of } \\
\text { doubts }\end{array}$ \\
\hline Repsol (Vicuña) & dismissed & $\begin{array}{l}3 \cdot 1.5, \text { if cases } \\
\text { related }\end{array}$ \\
& &
\end{tabular}

\begin{tabular}{lll} 
Tidewater & dismissed & 3.1 .3 \\
\hline Universal Compression & dismissed & 3.1 .3 \\
\hline Ickale & dismissed & 3.1 .3 \\
\hline Caratube & upheld & 3.3 .8
\end{tabular}

S\&T Oil resignation $\quad 3.4 .1$

depending on

finding of justifiable doubts

Blue Bank

upheld

$3 \cdot 4 \cdot 1$

\begin{tabular}{lcc} 
ConocoPhillips cases & dismissed & 3.1 .4 , upon merger \\
\hline Favianca cases & dismissed & 3.1 .4 , upon merger
\end{tabular}


FIGURE 3 ICSID challenges with unclear outcome under IBA guidelines (cont.)

Basis for Challenge

Familiarity with Contact with a Party

a Participant merely occasional contacts

previous public servant role

\begin{tabular}{ll}
$\begin{array}{l}\text { Contact with a Counsel } \\
\text { or Law Firm Representing } \\
\text { a Party }\end{array}$ & $\begin{array}{l}\text { affiliation of law firms } \\
\text { (of arbitrator and counsel) }\end{array}$ \\
\cline { 2 - 2 } & $\begin{array}{l}\text { previous collaboration } \\
\text { (of arbitrator and }\end{array}$ \\
& counsel or law firm) \\
& shared educational history
\end{tabular}

Role Switching

Repeat Appointment by a party or by a law firm /

counsel

Familiarity with

Subject-Matter

public servant role

law clerk discussed

legal questions online

Connection to

Adverse Third

Party decision could impact parallel

proceeding, in which related

counsel

is adverse to party

brother serves as arbitrator in

parallel proceeding 
ICSID Case

$\begin{array}{lll}\text { Outcome } & \text { Relevant } & \text { Hypothetical } \\ \text { under ICSID } & \text { Provision in IBA } & \text { Outcome under IBA } \\ \text { Convention \& } & \text { Guidelines } & \text { Guidelines } \\ \text { Rules } & & \end{array}$

Zhinvali

dismissed

none

uncertain

Generation Ukraine dismissed none

Amco Asia

dismissed none

uncertain

Repsol (Wobeser) dismissed none

\begin{tabular}{llll} 
Alpha Projektholding & dismissed & none & \\
\cline { 1 - 3 } SGS & dismissed & none & \\
\cline { 1 - 3 } Azurix & dismissed & none & \\
\hline Siemens & dismissed & none & uncertain
\end{tabular}

$\begin{array}{lll}\text { Saint-Gobain } & \text { dismissed } & \text { none }\end{array}$ uncertain

Saint-Gobain

dismissed none

uncertain 
On the other hand, only three of the examined challenges were based on situations explicitly provided for in the Green List. None of the circumstances invoked as a basis for a challenge would be covered by the Red Lists:

FIGURE 4 ICSID challenges covered by IBA guidelines' green list

\begin{tabular}{llllll}
\hline Basis for Challenge & & $\begin{array}{l}\text { ICSID } \\
\text { Case }\end{array}$ & $\begin{array}{l}\text { Outcome } \\
\text { under ICSID } \\
\text { Convention \& } \\
\text { Rules }\end{array}$ & $\begin{array}{l}\text { Relevant } \\
\text { Provision } \\
\text { in IBA } \\
\text { Guidelines }\end{array}$ & $\begin{array}{l}\text { Hypothetical } \\
\text { Outcome under } \\
\text { IBA Guidelines }\end{array}$ \\
\hline $\begin{array}{lllll}\text { Familiarity with } \\
\text { Subject-Matter }\end{array}$ & $\begin{array}{l}\text { academic } \\
\text { publications }\end{array}$ & Urbaser & dismissed & 4.1 .1 & dismissed \\
\hline $\begin{array}{l}\text { Connection to } \\
\text { Adverse }\end{array}$ & $\begin{array}{l}\text { relationship with } \\
\text { third party which is }\end{array}$ & EDF & dismissed & 4.4 .2 & dismissed \\
\cline { 2 - 4 } & $\begin{array}{l}\text { potentially inter- } \\
\text { ested in outcome of } \\
\text { proceeding }\end{array}$ & Suez I & dismissed & 4.4 .2 & \\
& & & & & \\
\hline
\end{tabular}

Irrespective of the described deficiencies, it is noteworthy that at least some of the situations mentioned in the Orange List (such as repeat appointments beyond the defined thresholds) are strictly avoided by arbitrators and counsel. Even though, technically, such scenarios only call for a disclosure and may or may not be found to justify a disqualification, they are sometimes approached as if they were on a Red List. In this context, Judge Charles N. Brower - Judge of the Iran-Us Claims Tribunal, and one of today's most influential arbitrators has made the following statement:

I do not accept appointments, and have not been urged to accept appointments, by the same party or on the recommendation of the same counsel within the preceding three years. In fact, this situation is easy to avoid. ${ }^{877}$

877 Charles N. Brower, Sarah Melikian \& Michael P. Daly, Tall and Small Tales of a Challenged Arbitrator, in Challenges and Recusals of Judges and Arbitrators in International Courts and Tribunals 320, 336 (Chiara Giorgetti ed., 2015). 
In conclusion, the IвA Guidelines may effectively reduce the incidence of at least some quantifiable conflicts of interest, such as those caused by repeat appointments. Although they do not completely eliminate legal uncertainty with regard to arbitrator appointments, the uncertainty which remains (or which the Orange List creates) may actually have the beneficial effect of deterring arbitration users from making the specified appointments, in order not to be exposed to strategic challenges by the counterparty. ${ }^{878}$ In practice, this may lead to mechanical conflict checks in the selection of arbitrators, which do not sufficiently factor in the circumstances of the specific case. However, even a mechanical sensitivity to ethical limits to arbitrator appointments is better than none.

Sui Generis Dispute Resolution Mechanisms

\subsection{Relevance}

The Iran-United States Claims Tribunal and the Permanent Court of Arbitration share the hybrid nature of ICSID arbitration: 879 Structurally set-up as arbitration systems, and modelled after commercial arbitration, they are treaty or convention-based, and substantively deal with the obligations of States under public and public international law. 880 This "special type of arbitration" 881 is generally termed a sui generis or hybrid dispute resolution mechanism..$^{882}$

878 Stephan Wilske \& Michael Stock, Rule 3.3.7 of the IBA Guidelines on Conflicts of Interest in International Arbitration - The Enlargement of the Usual Shortlist?, 23 ASA BULLETIN 45, 48-49 (2005) (referring to this effect as a "codification effect," and explaining that "the majority of arbitrators will wish to avoid a confrontation.").

879 The Permanent Court of Arbitration also deals with international (inter-State) arbitration, but currently administers more investor-State cases. See Case Repository, Pending Cases, Permanent Court of Arbitration, http://173.254.28.178/ pcacases/web/allcases/ (last accessed on Dec. 30, 2016).

880 In the context of investment arbitration, see DiE HL, supra note 463, at 3 ; Rainer Hofmann \& Christian J. Tams, International Investment Law: Situating an Exotic Special Regime within the Framework of General International Law, in InTE RNATIONAL INVESTMENT LAW AND General international Law: From Clinical Isolation to Systemic InteGRATION? 9, 9 (Rainer Hofmann \& Christian J. Tams eds., 2011); Zachary Douglas, The Hybrid Foundations of Investment Treaty Arbitration, 74 BRIT. Y. B. INT'L. L. 151,152-153(2003).

881 David D. Caron, The Nature of the Iran-United States Claims Tribunal and the Evolving Structure of International Dispute Resolution, 84 AM. J. INT'L. L. 104, 104-106 (1990) [hereinafter Caron, The Nature of the Iran-Us Claims Tribunal].

882 See Crawford, supra note 464, at 23 ("But to say that something is hybrid is really an English way of saying 'sui generis'. Lawyers have a habit of putting labels, especially Latin 


\subsection{The Iran-United States Claims Tribunal}

The Iran-United States Claims Tribunal is an international arbitral tribunal set up to adjudicate the claims of American citizens against Iran, arising from the political crisis and the disruption of economic relations in the wake of the 1979 Islamic Revolution. ${ }^{883}$ It is composed of nine arbitrators, of which three are appointed by each State party (the United States and Iran), and three (who are neither Iranian nor U.S. nationals) are appointed by agreement of the six party-appointed arbitrators. ${ }^{884}$ The Tribunal hears cases in chambers of three arbitrators, consisting of one arbitrator from each of the described groups. ${ }^{885}$ Only disputes between the two governments and cases referred to the tribunal from the chamber are heard by the tribunal en banc.

The Iran-Us Claims Tribunal conducts its business in accordance with the UNCITRAL Arbitration Rules. ${ }^{886}$ As provided therein, arbitrator challenges are decided by the Appointing Authority, ${ }^{887}$ in application of a justifiable doubts standard, from the perspective of a reasonable third person. ${ }^{888}$

Since its inception, a number of arbitrator challenges have been lodged before the Iran-Us Claims Tribunal. ${ }^{889}$ Because the Tribunal was established

labels, on things and thinking that this solves the problem ... To say that something is sui generis is to postpone the analysis and not engage in it.").

883 Declaration of the Government of the Democratic and Popular Republic of Algeria Concerning the Settlement of Claims by the Government of the United States of America and the Government of the Islamic Republic of Iran, Jan. 19, 1981 art. 2, para. 1 [hereinafter Claims Settlement Declaration]; CARon and Caplan, supra note 91, at 4; Posner and Yoo, Judicial Independence, supra note 119, at 8-9 and 33-34; Caplan, supra note 271, at 115 .

884 Claims Settlement Declaration art. 3, para. 1.

885 Buechel, supra note 493, at 247; CARON AND CAPLAN, supra note 91, at 5.

886 Claims Settlement Declaration art. 3, para. 2. Since its decisions are public, it creates the most extensive body of case law on the rules (CARON AND CAPLAN, supra note 91, at 183; Caplan, supra note 271, at 119).

887 Four individuals have served as the Appointing Authority so far: Judge Charles Moons (former Chief Justice of the Supreme Court of the Netherlands), Sir Robert Jennings (former President of the ICJ and Professor at Cambridge University), W.E. Haak (former Chief Justice of the Supreme Court of the Netherlands), and Geert J.M. Corstens (also a former Chief Justice of the Supreme Court of the Netherlands). See Caplan, supra note 271, at 120 (highlighting that the fulfillment of all of the functions of the Appointment Authority by one individual, and on a permanent basis, has brought stability and consistency to the Tribunal's work and to the challenge case law).

888 See supra Part 2.2. UnCITRAL Rules art. 10-13 are incorporated by the Tribunal Rules of Procedure, Iran-U.s., art. 9-12, May 3, 1983 [hereinafter Tribunal Rules].

889 CARon AND CAPlan, supra note 91, at 183-191; Caplan, supra note 271, at 138-139. Remarkably, none of the challenges were upheld. In three instances, however, the challenged arbitrators resigned, or were withdrawn by their appointing party. See Caplan, supra note 271 , at 122 . 
for the resolution of disputes arising in a very specific setting, and the arbitrators have a quasi-judicial role, however, the conflict categories invoked before the Iran-Us Claims Tribunal are often different from those arising in the investment and commercial arbitration context. For example, challenges based on an arbitrator's familiarity with the subject-matter of the proceeding would make little sense, since all arbitrators have previously adjudicated cases in which claims arising from the same or similar factual settings were at stake. Similarly, the Iran-us Claims Tribunal's arbitrators are continuously involved in cases between U.s. citizens and the Islamic Republic of Iran - accordingly, it would not make sense to base a challenge on the arbitrators' familiarity with either of the States. The permanent, quasi-judicial function of the nine arbitrators as members of the Iran-Us Claims Tribunal's "bench" further logically excludes the issue of repeat appointments and role switching. Overall, an arbitrator's familiarity with one of the State parties or with the subject-matter of the case is an inadequate basis for a challenge.

As a result of this, most challenges of Iran-Us Claims Tribunal arbitrators have been based on the arbitrators' behavior in the respective proceedings. The factual background of these challenges is often rather crass, ${ }^{890}$ and the decisions are of limited relevance for the comparison with ICSID case law. These cases will not be analyzed hereinafter. Instead, only those decisions which are useful as a source of inspiration for the conflicts of interest alleged in the ICSID system $^{891}$ and analyzed in Chapter 2 will be examined.

In one case, ${ }^{892}$ the Swiss third-party arbitrator Judge Briner was challenged based on his previous role as a director of an inactive Swiss subsidiary of Morgan Stanley. Morgan Stanley was now an important expert witness in the proceeding. The challenging party argued that because of his past relationship with Morgan Stanley, Judge Briner could not objectively assess the witness's credibility.

While it was generally agreed that an arbitrator's familiarity not only with a party, but also with another participant in the proceeding (such as a witness)

890 See, e.g., the challenge of Judges Kashami and Shafeiei by the U.s. Government, based on their violent physical assault against a fellow member of the tribunal, reported in CARON AND CAPLAN, supra note 91, at 184 (case 2) and 225 (case 12). See also Caplan, supra note 271, at 116 (explaining that the many challenges to the Tribunal's arbitrators bear testimony the climate of distrust between the governments).

891 Challenges based on the arbitrator's behavior are not analyzed in detail, even where procedural or substantive flaws in their decisions were alleged. Such allegations are common to all dispute resolution systems and do not appear to raise specific concerns in the ICSID system.

892 Case No 55, Amoco Iran v. Islamic Republic of Iran, Challenge of Judge Briner by Iran, reported in CARON AND CAPLAN, supra note 91, at 184 (case 3) and 215 (case 1); Caplan, supra note 271 , at $123-124$. 
could give rise to justifiable doubts, the challenge hinged on the determination whether the specific relationship between Judge Briner and Morgan Stanley was substantial enough. ${ }^{893}$ An arbitrator's relationship with a subsidiary or affiliate of a large multinational corporation, it was argued, could not be automatically disqualifying, since it would otherwise be impossible for such corporations to find experienced and competent arbitrators. ${ }^{894}$ This objection stands to reason where such multinational corporations are only indirectly connected to an arbitrator (for example, where another lawyer in the arbitrator's firm represents or advises the company). In this specific case, however, the arbitrator himself was closely involved with the company, and it appears unlikely that any other third country arbitrator on the tribunal had an equally close connection. The challenge did not need to be decided, however, since Judge Briner eventually recused himself, under protest. ${ }^{895}$

In another case, ${ }^{896}$ the disqualification of the arbitrator appointed by Iran, Judge Noori, was requested. Judge Noori was the former general counsel of the parent corporation of the Respondent, the NIOI Legal Office. The Appointing Authority dismissed the challenge, stating that the situation did not raise justifiable doubts.

According to Caron and Caplan, this decision was made "much too readily" 897 and is out of line with the UNCITRAL practice. Rather than validating a lower expectation of independence and impartiality from party-appointed arbitrators, the decision should be seen as a reflection of the unusually low impartiality expectations placed on Iranian-appointed arbitrators in the Iran-Us Claims Tribunal. ${ }^{898}$ Apparently, a certain degree of partiality and dependence of the United States' and Iranian arbitrators came to be tolerated before the Claims Tribunal, based on the pragmatic observation that the disqualification of such arbitrators would ultimately result in the appointment of equally objectionable replacement arbitrators. Furthermore, obviously biased arbitrators were ineffective in deliberations, and therefore nothing to worry about. 899

\footnotetext{
893 CARON AND CAPLAN, supra note 91, at 215-216.

894 Id. at 216.

895 Id. at 184.

896 Case No 248, Carlson v. Melli Industrial Group, Challenge of Judge Noori by the U.s. Claimant, reported in CARON AND CAPLAN, supra note 91, at 186 (case 6) and 217 (case 4).

897 CARON AND CAPLAN, supra note 91, at 217.

898 Id. at 217. This interpretation is confirmed by the Appointing Authority in its decision on the Challenge of Judge Skubiszewski and Judge Gaetano Arangio-Ruiz by Iran in Case No B81 (infra note 900), where a lower standard for party-appointed arbitrators was expressly rejected. See CARON AND CAPLAN, supra note 91, at 199 and 222.

899 CARON AND CAPLAN, supra note 91, at 210.
} 
In a third case, ${ }^{900}$ Judge Skubiszewski and Judge Gaetano Arangio-Ruiz were challenged because they had been involved in an allegedly illegal revision of the partial award in a parallel proceeding (Case A15). The challenging party argued that the revision violated the principle of res judicata, and that it was prejudicial in the current case, because Iran had based many of its submissions on the partial award in Case A15. The Appointing Authority dismissed the challenge, since it was belated and because the violation of the principle of res judicata was unsubstantiated. ${ }^{901} \mathrm{~A}$ much more fundamental question raised by this constellation, however, is whether arbitrators should adjudicate disputes whose outcome is prejudicial to other cases, in which they sit as arbitrators or represent a party. Unfortunately, this question could only have been broached if the challenge had been brought in Case A15.

Finally, an arbitrator was challenged based on his prior involvement with the subject-matter of the case. He had allegedly sat as an arbitrator in an ICC proceeding concerning the same facts thirteen years earlier. The challenge was dismissed because the claims in the two arbitration proceedings had different legal bases, and because the disqualification request was belated. ${ }^{902}$

\subsection{The Permanent Court of Arbitration}

The PCA was established at the Hague Peace Conferences of 1899 and $1907 \cdot{ }^{903}$ Despite its name, it is not a court in the traditional sense, nor is it a permanent arbitration body with mandatory jurisdiction. Instead, it is an optional facility for arbitration, which provides disputing parties with a roster of potential nominees which they may appoint as arbitrators, with secretarial and registry services for ad hoc arbitration, and with different sets of procedural rules..$^{904}$

Originally, the Hague Conventions intended the roster of Members of the Court to be exhaustive: Each contracting State could nominate up to four

900 Case No B61, Challenge of Judge Skubiszewski and Judge Gaetano Arangio-Ruiz by Iran, reported in CARON AND CAPLAN, supra note 91, at 189-190 (case 13) and 222-223 (case 10).

901 CARON AND CAPlan, supra note 91, at 190; Caplan, supra note 271, at 127-128.

902 Case No B61, Challenge of Judge Seyed Jamal Seifi by the U.s. Government, reported in CARON AND CAPLAN, supra note 91, at 190 (case 14).

903 See 1899 Convention for the Pacific Settlement of International Disputes, Jul. 29, 1899 [1899 The Hague Convention]; 1907 Convention for the Pacific Settlement of International Disputes, Oct. 18, 1907 [1907 The Hague Convention] [collectively referred to as the Hague Conventions].

904 By providing such administrative assistance for arbitral proceedings, the PCA overcomes the most important hurdles faced by earlier arbitration mechanisms, namely difficulties regarding the appointment of arbitrators and regarding the applicable procedural rules. See Charles H. Brower, The Functions and Limits of Arbitration and Judicial Settlement 
individuals for the Court, but disputing parties would then be restricted by the roster in their choice of arbitrators. ${ }^{905}$ This does not, however, correspond to the practice of the PCA. The Hague Conventions enable parties to appoint whomever they wish to a "special Board of Arbitration." ${ }^{906}$ Since this term is not defined, the provision is used for all arbitral tribunals; hence, parties can freely choose their decision-makers. Furthermore, the various PCA Arbitration Rules explicitly allow parties and the Appointing Authority to designate persons who are not members of the Court as arbitrators. ${ }^{907}$

Members of the Court are required to have a "known competency in questions of international law, [be] of the highest moral reputation, and [be] disposed to accept the duties of [an] Arbitrator." ${ }^{\prime 908}$ While the Hague Conventions do not mention the terms independence or impartiality in the context of the Members of the Court or arbitrators, ${ }^{909}$ both qualities are explicitly named as appointment criteria in various PCA Rules. ${ }^{910}$ These rules also allow parties to challenge arbitrators if the circumstances give rise to justifiable doubts as to their independence or impartiality. ${ }^{911}$ Such challenges are determined by an Appointing Authority, similarly to UNCITRAL challenges. ${ }^{912}$

Under Private and Public International Law, 18 DU Ke J. Comp. \& INT'L. L. 259, 276 (2008); Nisuke Ando, Permanent Court of Arbitration (PCA), in Max Planck Encyclopedia of Public International Law, I 2 (2006), online edition, available at http:/opil .ouplaw.com/home/epil; Karin Oellers-Frahm, International Courts and Tribunals, Judges and Arbitrators, in Max Planck Encyclopedia of Public International Law, $\mathbb{q}$ 3 (2013), online edition, available at http://opil.ouplaw.com/home/epil.

9051899 The Hague Convention art. 24; 1907 The Hague Convention art. 45 .

9061899 The Hague Convention art. 26; 1907 The Hague Convention art. 47.

907 PCA Optional Rules for Arbitrating Disputes Between two Parties of which only one is a State, Jul. 6, 1993 [hereinafter PCA Optional Rules] art. 8, para. 3; Permanent Court of Arbitration Arbitration Rules 2012, Dec. 17, 2012 [hereinafter PCA Arbitration Rules 2012] art. 10, para. 4. See Daly, Goriatcheva, And Meighen, supra note 637, ๆ 4.37-4.38.

9081899 The Hague Convention art. 23; 1907 The Hague Convention art. 44.

909 On the contrary, 1907 The Hague Convention art. 62 allowed Members of the Court to also act as "agents, counsel, or advocates" for the State which appointed them. See Anja Seibert-Fohr, International Judicial Ethics, in The Oxford HANDbook of InTERnAtional Adjudication 757, 759-760 (2013).

910 Common art. 6, para. 4 of the PCA Optional Rules, the PCA Optional Rules for Arbitration of Disputes Relating to Natural Resources and/or the Environment (Jun. 19, 2001), the PCA Optional Rules for Arbitration Between International Organizations and Private Parties (Jul. 1, 1996), and the PCA Optional Rules for Arbitrating Disputes Between two States (Oct. 20, 1992).

911 See, e.g. PCA Optional Rules art. 10, para. 1; PCA Arbitration Rules 2012 art. 12, para. 1.

912 PCA Optional Rules art. 12. See Sheppard, supra note 32, at 135. 
The PCA has recently been at the center of the debate about arbitrator independence and impartiality: Tapped phone conversations of Mr. Sekolec, ${ }^{913}$ an arbitrator in a maritime border delimitation dispute between Croatia and Slovenia, revealed that he shared confidential information about the tribunal deliberations and the likely outcome of the proceeding with a member of Slovenia's foreign ministry, Ms. Drenik. Mr. Sekolec explained in great detail how he intended to influence other arbitrators on the tribunal, and place additional information before them during deliberations. ${ }^{914}$ Together with Ms. Drenik, he meticulously planned how she was to prepare notes on the delimitation of a specific part of the border, which he would then present to the tribunal as his own, making sure they would be included as a "part of the future award." 915

Mr. Sekolec, a former Secretary General of UnCitral and LCiA Vice President, resigned from the tribunal as a consequence of the scandal, while Croatia announced that it would withdraw from the "contaminated" proceeding, since its lawfulness and credibility had been compromised. ${ }^{916}$ The reconstitution of the tribunal was disrupted several times, and therefore delayed: The replacement arbitrator appointed by Slovenia, Ronny Abraham, ${ }^{917}$ resigned after only a short while - the Croatian parliament had voted in favor of the country's withdrawal from the arbitration, leading in turn to the resignation of the arbitrator appointed by Croatia, Budislav Vuvac. ${ }^{918}$ The resulting vacancies on the tribunal were later filled by the president of the tribunal. ${ }^{919}$

913 Mr. Sekolec had been appointed to the five member tribunal by Slovenia. See Alison Ross, Croatia says it will withdraw over Sekolec scandal, Global Arbitration Review (July 27, 2015), http://globalarbitrationreview.com/news/article/34009/croatia-withdraws-sekolec -scandal/ [hereinafter Ross, Croatia].

914 Id.

915 Alison Ross, The tapped conversations: what Sekolec said, Global Arbitration Review (Aug.19,2015),http://globalarbitrationreview.com/news/article/3407o/what-sekolec-said/ [hereinafter Ross, Tapped Conversations].

916 Ross, $\underline{\text { Croatia, supra note } 913 .}$

917 Alison Ross, Slovenia replaces Sekolec, Global Arbitration Review (July 28, 2015), http:// globalarbitrationreview.com/news/article/34017/slovenia-replaces-sekolec/.

918 Alison Ross, ICJ_president backs out of Croatia-Slovenia dispute, Global Arbitration Review (Aug. 5, 2015), http://globalarbitrationreview.com/news/article/34038/icj -president-backs-croatia-slovenia-dispute/.

919 Douglas Thomson, New faces on troubled Balkan border panel, Global Arbitration Review (Sept. 25, 2015), http://globalarbitrationreview.com/news/article/34178/new-faces-troubled-balkan-border-panel/ (Slovenia had asked the president to appoint a replacement arbitrator, in order to preserve the integrity of the proceedings, while Croatia insisted that it withdrew from the arbitration, and refused to appoint a replacement arbitrator). 
The thus reconstituted tribunal decided that Croatia was not entitled to withdraw from the proceeding: after a de novo consideration of all aspects of the case, the Tribunal would be able to render a final award independently and impartially. ${ }^{920}$

While this case is certainly exceptional, it serves as a reminder of the importance of arbitrators' independence and impartiality for the legitimacy of a proceeding, of a tribunal, and of the entire dispute resolution mechanism. Other breaches of the obligation to act independently and impartially may be more nuanced, and difficult to detect, but will have a similar effect in aggregate, if they are tolerated.

\subsection{Contextualization and Conclusion}

The sui generis character of the Iran-us Claims Tribunal's dispute resolution mechanism might suggest that its challenge decisions are of particular relevance for the ICSID system. A number of idiosyncrasies, however, limit the pertinence of its disqualification case law for the ICSID system. In particular, the permanent arbitral panel, predominantly stocked with arbitrators nominated by the only two participants to the mechanism, eliminates certain conflict categories from the outset.

Generally, the State parties have come to tolerate a certain degree of bias in their respective counterparty's appointees. As a consequence, most challenges are directed against third-country arbitrators. ${ }^{921}$ These challenges are mainly based on the arbitrators' behavior. In the rare case where a disqualification request concerns an arbitrator appointed by the U.s. or by Iran, the standard applied is usually very lenient.

Such a practice may make sense from a pragmatic standpoint of procedural efficiency in the context of the Iran-Us Claims Tribunal: The pool of available arbitrators is truly small and the same two States are involved in all cases. It is plausible that the disqualification and replacement of a State-appointed arbitrator would ultimately not lead to a more satisfactory result. ${ }^{922}$ The Claims Tribunal is however very distinctive in this respect - accordingly, its case law should be interpreted as decisions "confined to the facts of a particular case

920 See PCA Press Release, Tribunal Issues Partial Award: Arbitration Between Croatia and Slovenia to Continue (June 30, 2016), available at https://pca-cpa.org/wp-content/uploads/sites/175/2016/o7/PCA-Press-Release-30o62016.pdf.

921 CARON AND CAPLAN, supra note 91, at 210. It is noteworthy, however, that while only one of twelve challenges brought by the Iranian government was directed against a U.s. arbitrator, all but one of the eight challenges brought by the U.s. government were directed against Iranian arbitrators. See Caplan, supra note 271, at 122 and 129.

922 Caplan, supra note 271, at 136. 
and institution," which do not predetermine how the same constellations would be dealt with in another setting. ${ }^{923}$

The delimitation of independence and impartiality under the various PCA Arbitration Rules, and the interpretation of the justifiable doubts threshold stipulated therein, is undiscernible. It is likely that it corresponds with the PCA Secretary-General's interpretation in cases under the UNCITRAL Arbitration Rules $^{924}$ and under the ICSID Convention. ${ }^{925}$

\section{$5 \quad$ Summary Analysis}

\subsection{Basic Consensus}

Summing up the results of the comparative research laid out in this Chapter, there is a general consensus in all examined dispute resolution mechanisms: Decision-makers must fulfil certain minimum requirements of independence and impartiality. Parties can generally challenge arbitrators and ad hoc judges if they believe that those requirements are not met. Most systems provide for an actual challenge or disqualification proceeding, while the ICJ uses a different terminology, but with the same result: A disputing party has a right to voice its concerns, and can, under certain conditions, achieve the removal of an ad hoc judge from the proceeding.

\subsection{Prevalent Threshold}

The threshold for a disqualification is relatively uniform across the examined dispute resolution mechanisms. Justifiable doubts regarding an arbitrator's independence and impartiality will lead to a disqualification under all examined commercial arbitration rules, including the UNCITRAL Rules, as used in commercial disputes, but also by the Iran-Us Claims Tribunal, and as transposed into various of the PCA Arbitration Rules. The IBA Guidelines provide for the same standard: Justifiable doubts suffice for a disqualification.

Only the two international adjudication mechanisms which were examined provide for different thresholds. The ICJ Rules authorize a party to file a disqualification request if it "desires to bring to the attention of the Court facts which it considers to be of possible relevance." ${ }^{926}$ The scope of possibly

923 Caron and Caplan, supra note 91, at 211. See also Caron, The Nature of the Iran-US Claims Tribunal, supra note 881, at 104.

924 See Telekom Malaysia.

925 See Abaclat I, Generation Ukraine, and Perenco.

926 ICJ Rules art. 34, para. 2. 
relevant facts is however significantly narrowed down by Article 17 para. 2 ICJ-Statute, which Article 34 para. 2 has to be read in conjunction with. As a consequence, challenges are limited to an ad hoc judge's previous participation in the same case. In comparing this standard to disqualification standards in investment or commercial arbitration, it is important to keep in mind that the influence of an ICJ ad hoc judge on the outcome of a particular proceeding is very modest. Since she or he is only one of fifteen judges deciding on a case, the narrowly outlined challenge grounds are unlikely to have an effect on the outcome of the proceeding or on the legitimacy of a particular judgment. On a panel of three decision-makers, this question would have to be assessed differently.

The other international adjudication mechanism which provides for a different challenge threshold is dispute settlement in the wTo. Section VIII of the Rules of Conduct allows parties to challenge panelists based on material violations of their obligations of independence and impartiality, and of their duty to avoid conflicts of interest, which may impair the integrity, impartiality or confidentiality of the dispute settlement mechanism. As has been stated above, it is not entirely clear how this "proof of material violation" standard compares to the more common justifiable doubts standard. Presumably, it imposes a higher burden of proof on the challenging party. But as in the ICJ context, there is an important limitation to the comparability of this standard to disqualification standards in investment or commercial arbitration: WTO panelists are appointed in a less party-driven process, either by an agreement of the parties, or (more frequently) by the Director-General. Accordingly, both parties have the same degree of influence (or lack thereof) on the panelists. This might eliminate certain suspicions from the outset, and explain the appropriateness of a higher threshold. ${ }^{927}$

In summary, all examined dispute resolution mechanisms which are comparable with the ICSID system require justifiable doubts regarding the arbitrator's independence and impartiality in order for a challenge to succeed.

\subsection{Effect of the Threshold on the Outcome}

This raises the question whether challenges subject to a justifiable doubts standard have noticeably different outcomes than ICsID challenges. The answer to this question is not as simple as existing criticisms of ICSID arbitration suggest:

927 Nadakavukaren Schefer, supra note 82 , at $235^{-238}$ (exploring the possible reasons for the scarcity of challenges and the lack of an academic discussion regarding arbitrator challenges in the WTO system). 
First, the disqualification of decision-makers is an exceptional occurrence in all examined systems. This makes sense, given the disturbance of the proceeding and the delay which a disqualification entails, as well as the need to eliminate spurious challenges.

Second (and perhaps more surprisingly), challenges based on comparable circumstances are not adjudicated more strictly across the board when a justifiable doubts threshold is applied. The lower threshold only appears to lead to more disqualifications in some constellations, while other situations are similarly evaluated.

\section{A}

Main Discrepancies

Arbitrators were more frequently disqualified in the examined dispute resolution mechanisms based on their familiarity with a party in the proceeding, in particular where an attorney-client relationship or repeat appointments were invoked.

Even superficial, infrequent or commercially irrelevant prior contacts with a party generally led to disqualifications under the SCC Arbitration Rules, while ICC challenge decisions took factors such as the timing of the contacts, the closeness of the relationship and its commercial significance into account, before making a precautionary decision.

Attorney-client relationships between an arbitrator (or the arbitrator's law firm) and a party were generally held to be incompatible with the role of commercial arbitrators - irrespective of whether the issues involved in the arbitration and the subject-matter of the attorney-client relationship were related or similar.

Repeat appointments by a party generally led to the arbitrator's disqualification - subject, of course, to the number and frequency of such appointments.

Arbitrators who previously dealt with the subject-matter of a proceeding were also more frequently disqualified in commercial arbitration than in the ICSID system.

Finally, an important difference in the evaluation of challenges based on an arbitrator's familiarity with a party or with the subject-matter came to light in the comparison: The requirement of an overlap of the parties, law and facts of the matters in which an arbitrator is simultaneously or successively involved - a condition which blocks numerous ICSID challenges - either does not exist, or is not applied as strictly in any of the examined dispute resolution mechanisms. ${ }^{928}$ This condition is unique to ICSID challenge decisions.

928 See Grand River for an application of this requirement under the UnCITRAL Arbitration Rules. In this case, a "basic similarity" of the matters was affirmed, because both 
Irrespective of the applicable threshold, arbitrators who have previously been involved in the same dispute were disqualified in all examined systems. Disqualifications have occurred under the SCC and ICC Arbitration Rules, while no such cases have been reported in the UNCITRAL and ICSID systems. Under the IBA Waivable Red List, arbitrators which were previously involved in the same dispute are presumed to be barred from sitting on the tribunal. Article 17 para. 2 ICJ-Statute prohibits the involvement of ad hoc judges at different stages of the same proceeding - but only in certain functions. This broad consensus is not surprising: It epitomizes an elementary guarantee of procedural fairness.

In all examined systems, previous contacts between an arbitrator and a counsel are presumed to be unproblematic. They have only led to disqualifications in exceptional circumstances, for example where the arbitrator's law firm and the law firm of counsel shared office space and held joint seminars, or where the arbitrator's spouse was a partner in the law firm which had nominated him.

Furthermore, challenges were generally dismissed in all examined systems when brought on the basis of an arbitrator's previous public servant role, whether the challenging party found fault with the arbitrator's ensuing connection to a party or her or his familiarity with the subject-matter.

Challenges based on academic publications on the subject-matter of the dispute appear to only have been filed (and dismissed) in the ICSID system. The IBA Guidelines' listing of such publications on the Green List implies a broad consensus that they should not lead to an arbitrator's removal.

Finally, an analogy affecting several conflict categories is worth mentioning: Decisions in the ICSID and UNCITRAL systems have similarly dealt with the question whether an arbitrator who exercises two conflicting roles at the same time should be able to avoid disqualification by ceasing one of these roles, and answered in the affirmative. ${ }^{929}$ These cases raise interesting questions, not

proceedings dealt with the United States' compliance with its international commitments. Challenges based on repeat appointments have been upheld under the ICC Arbitration Rules where the same particular or even general subject-matter was at issue, even if the facts and parties did not overlap. Finally, the provisions of the IBA Guidelines' Orange List concerning repeat appointments only require the issues to be related where repeat appointments against a party are at issue, but not in the context of repeat appointments by a party or a counsel or law firm.

929 Challenges in the ConocoPhillips and Favianca cases have been dismissed based on Mr. Fortier's resignation from Norton Rose. In Azurix and Siemens, Mr. Sureda's 
only from the perspective of cognitive psychology, but also theoretically: Can justifiable doubts, once they have arisen, effectively be dispersed based on a formal act of the arbitrator which serves his own purpose?

\section{Gaps in the Case Law}

Apart from the above-mentioned differences and similarities, there are also gaps in the case law of the examined dispute resolution mechanisms. Some circumstances which have been the basis for challenges in the ICSID system have not (yet) been invoked very often in any of the other systems, or have led to widely disparate outcomes. In these categories, there is no sufficient basis for a comparative analysis of ICSID challenge decisions.

Very few challenges have been filed based on an arbitrator's previous collaboration with counsel for one of the parties, or with the law firm representing one of the parties. Role switching has also only been invoked infrequently. ${ }^{930}$ The same can be said for repeat appointments by a law firm or counsel ${ }^{931}$ and repeat appointments against a party. ${ }^{932}$

Challenges based on an arbitrator's connection with an adverse third party have led to varying results. Two UNCITRAL challenges were upheld, while another two were dismissed. The ICc challenge in Saudi Cable was also dismissed. How this category of cases should be dealt with appears not to be settled.

The following Chapter will analyze existing improvement suggestions based on these findings.

termination of his employment with Fulbright \& Jaworski allowed him to avoid disqualification. In Grand River and Telekom Malaysia, the respective arbitrators' disinvolvement in other matters has enabled them to remain on the tribunals. In Vito Gallo, the arbitrator recused himself, but could have foregone disqualification by discontinuing his advisory services to Mexico.

930 The scarcity of challenges based on such circumstances might be due to the larger size of the pool of commercial arbitration professionals, compared to the size of the investment arbitration community.

931 It is conceivable that arbitration practitioners consciously refrain from repeat appointments which would be covered by the IвA Guidelines' Orange List, in order to avoid excessive exposure to challenges by their counterparty. See Wilske and Stock, supra note 878 , at $48-49$.

$93^{2}$ Repeat appointments against a party are likely to be less common in systems where the pool of potential respondents is larger. 